SOVEREIGN DEBT IN THE 21ST CENTURY

Kris James Mitchener

Christoph Trebesch

WORKING PAPER 28598 
NBER WORKING PAPER SERIES

\title{
SOVEREIGN DEBT IN THE 21ST CENTURY
}

\author{
Kris James Mitchener \\ Christoph Trebesch \\ Working Paper 28598 \\ http://www.nber.org/papers/w28598 \\ NATIONAL BUREAU OF ECONOMIC RESEARCH \\ 1050 Massachusetts Avenue \\ Cambridge, MA 02138 \\ March 2021, Revised June 2022
}

This survey paper was prepared for the Journal of Economic Literature. We thank the Editor, Steven Durlauf, as well as four anonymous referees for very helpful comments and suggestions. We thank Matthew Cunningham, Jonathan Öztunc, Torge Marxsen, Brenton Stefko and Thore Petersen for very helpful research assistance and Josefin Meyer and Lucie Stoppok for sharing data and making suggestions. We further thank Andreea Maerean, Rui Esteves, Galine Hale, Steve Haber, Kim Oosterlinck, and Noel Maurer for helpful discussion and comments. Trebesch gratefully acknowledges financial support from the German Research Foundation (DFG, SPP 1859). The views expressed herein are those of the authors and do not necessarily reflect the views of the National Bureau of Economic Research.

NBER working papers are circulated for discussion and comment purposes. They have not been peer-reviewed or been subject to the review by the NBER Board of Directors that accompanies official NBER publications.

(C) 2021 by Kris James Mitchener and Christoph Trebesch. All rights reserved. Short sections of text, not to exceed two paragraphs, may be quoted without explicit permission provided that full credit, including $\left({ }^{\circ}\right.$ notice, is given to the source. 
Sovereign Debt in the 21st Century

Kris James Mitchener and Christoph Trebesch

NBER Working Paper No. 28598

March 2021, Revised June 2022

JEL No. F30,F34,G12,G15,N10,N20

\begin{abstract}
How will sovereign debt markets evolve in the 21 st century? We survey how the literature has responded to the eurozone debt crisis, placing "lessons learned" in historical perspective. The crisis featured:(i) the return of debt problems to advanced economies; (ii) a bank-sovereign "doom-loop" and the propagation of sovereign risk to households and firms; (iii) roll-over problems and self-fulfilling crisis dynamics; (iv) severe debt distress without outright sovereign defaults; (v) large-scale sovereign bailouts from abroad; and (vi) creditor threats to litigate and hold out in a debt restructuring. Many of these characteristics were already present in historical debt crises and are likely to remain relevant in the future. Looking forward, our survey points to a growing role of sovereign-bank linkages, legal risks, domestic debt and default, and of official creditors, due to new lenders such as China as well as the increasing dominance of central banks in global debt markets. Questions of debt sustainability and default will remain acute in both developing and advanced economies.
\end{abstract}

Kris James Mitchener

Department of Economics

Leavey School of Business

Santa Clara University

Santa Clara, CA 95053

and NBER

kmitchener@scu.edu

Christoph Trebesch

Kiel Institute for the World Economy

Research Area on International Finance

Kiellinie 66,

24105 Kiel,

Germany

and CEPR and CESifo

christoph.trebesch@ifw-kiel.de 


\section{Introduction}

In 2020, as we enter the third decade of the 21st century, sovereign debt levels around the world are reaching record highs. The Covid-19 pandemic and its economic effects have triggered a global sovereign borrowing boom that is almost unparalleled in history. How will governments deal with rising debt burdens? Why are creditors willing to lend to highly indebted sovereigns and what happens if they suddenly stop doing so? Can we expect a new wave of defaults, and, if so, what toll will they take on economies, both developing and developed? These are highly topical questions, but all of them have antecedents in history. ${ }^{1}$

In this survey, we look back to better understand the challenges that lie ahead. In particular, we examine the large body of sovereign debt research that has emerged since the crash of 2007-9 and the subsequent eurozone debt crisis of 2010-12. Most previous surveys on the topic have focused on sovereign debt problems of developing countries in the past decades, motivated by defaults in Latin America, Africa, and Asia in the 1980s, 1990s, and 2000s. ${ }^{2}$ We spotlight issues that have been of particular relevance to advanced economies in recent decades, though our perspective is global and long run in that we compare sovereign debt markets and crises in advanced economies to those in emerging markets and throughout history, going back 200 years and more.

Our survey emphasizes advanced economy ${ }^{3}$ debt problems and lessons from the eurozone crisis, not just because many recent influential contributions have this focus, but also because the damage from the default of a present-day rich, "financialized," and highly integrated economy can be far reaching and consequential. In terms of lost output, the eurozone crisis certainly ranks among the costliest debt crises that ever happened. In comparison, the recent debt crises of Ukraine, Venezuela, or Lebanon were less consequential, both from a global and possibly also from a domestic perspective. That said, many emerging markets are becoming richer, and their financial sectors are expanding. EMEs now account for more than half of global GDP and the amounts of "South-South" lending and investments are growing fast. In a postpandemic world, high sovereign debt burdens and potential repayment problems will likely remain a challenge for both advanced and emerging economies in the coming years or decades.

\footnotetext{
${ }^{1}$ Early research on sovereign debt and default includes Clarke (1878), Manes (1918), Feis (1930), Winkler (1933) and Borchard and Wynne (1951).

${ }^{2}$ For example, see Panizza, Sturzenegger, and Zettelmeyer (2009) and Aguiar and Amador (2014). Surveys have also taken a longer-run historical perspective on defaults (Oosterlinck 2013). For a recent broad-based theoretical treatment see Aguiar and Amador (2021).

${ }^{3}$ By “advanced economies,” in general, we mean high-income, high-productivity, industrialized countries, many of which also have developed financial markets (though the variation in financial development is greater the farther we go back in time). Since our analysis is retrospective, a better term might be "leading economies," since measures such as GDP per capita can change considerably over longer sweeps of history. For simplicity, in the empirical analysis, we focus on 20 of today's industrial economies: Australia, Austria, Belgium, Canada, Denmark, Finland, France, Germany, Greece, Ireland, Italy, Japan, the Netherlands, Norway, Portugal, Spain, Sweden, Switzerland, the United Kingdom, and the United States.
} 
With this in mind, we ask: What can governments and creditors around the world learn from the eurozone crisis? And was this episode a harbinger for other countries and regions?

We divide our survey into two parts. The first part discusses five features of the eurozone crisis, each of which receives its own section in the article:

- Debt problems return to advanced economies

- Debt crises without default

- The transmission of sovereign risk to firms and the macroeconomy

- Bank-sovereign linkages and the emergence of "doom loops"

- Roll-over risks: why multiple equilibria and bond maturity matter

In this part of the survey, we focus on advanced economies, and sometimes, more specifically, on the eurozone and debt issues arising from its political institutions. Our long-run perspective allows us to examine which of these features are "new," and which, if any, are unique to the eurozone or to advanced economies.

The second part of our survey, consisting of the final three sections of the article, takes a global perspective and looks forward, examining three issues that are likely to dominate sovereign debt research and policymaking in the coming decades of the $21^{\text {st }}$ century, including in the eurozone. Specifically, sections seven to nine focus on:

- The rise of domestic debt and default

- International bailouts and the return of official lending

- Growing legal risk in sovereign defaults and restructurings

Throughout, our goal is to highlight new insights from the literature and to place them in the context of both theory and history. The theoretical view helps us to discipline our reading of events and of empirical results. The long-run view, in turn, helps to understand whether the models developed in response to the eurozone debt crisis hold more generally. Where appropriate, we supplement the discussion of the recent research with empirical "mini tests" from history, so as to place the lessons learned in a broader perspective.

With hindsight, our review of the evidence suggests that the eurozone crisis was not that special after all. As the crisis unfolded, after 2009, much of it felt new and unique, as no major crisis before had taken place in a monetary union with a powerful central bank at its core. Zooming out, however, many features bear a striking resemblance to earlier crises in emerging-market and advanced economies. Simply put, the eurozone crisis was just another external debt crisis and sudden-stop episode, which so many emerging markets have experienced over the past 200 years. Most of the debt was held abroad in a hard currency, the euro, so that debt stocks could not be inflated away, and any debt restructuring had to be negotiated with foreign banks and investors. The parallels are particularly strong with Mexico's 1994-5 crisis. Both episodes featured roll-over problems and self-fulfilling crisis dynamics, severe debt distress without default, sudden stops in private capital flows that were followed by large-scale rescue lending 
(bailouts) from abroad, and contagion to other sovereign bond markets in the region. From today's perspective, there is therefore much truth to the statement of former IMF director Camdessus that the so-called Tequila crisis was "the first crisis of the 21st century." Indeed, these features will more than likely be part of future advanced and emerging-market crises as well.

Section 2 sets the stage of our survey by exploring the re-emergence of sovereign debt problems in advanced economies. The eurozone debt crisis reminds us of two recurrent features from history: (i) debt crises happen relatively frequently and (ii) they happen in high-income or "advanced economies" as well as in lower or middle-income economies (often referred to as emerging markets). Indeed, history is replete with examples of defaults in the leading economies of the time - England with Edward III's default on debts owed to Italian bankers (the Peruzzi and the Bardi), France in the wake of the Napoleonic wars, Argentina during the Belle Epoque, and the U.S. when it abrogated the gold clause in the 1930s. In the past decades, however, researchers focused almost exclusively on sovereign lending problems in developing countries. This changed after 2009, when sovereign risk and repayment problems suddenly became a central macroeconomic policy issue in Athens, Dublin, and Rome. To place the crisis in perspective, we review the historical cases of advanced-economy default, such as those during the Great Depression and WWII. The return of advanced economy debt problems in the eurozone has served as a reminder to policy makers that debt sustainability is a core concern, regardless of a country's level of economic development. We thus explore recent research on debt dynamics, the interest rate-growth rate differential, and debt overhang. We also draw attention to the heavy reliance on the European Central Bank (ECB) to alleviate debt distress and fiscal pressures and relate these issues to debt sustainability. We show that central banks have, again, become large-scale holders of sovereign debt, at levels not seen since WWII.

Section 3 characterizes the phenomenon of "debt crises without default." According to traditional metrics, such as the definitions used by Reinhart and Rogoff (2009) or rating agencies like Standard \& Poor's, the eurozone crisis would not be classified as a "debt crisis." The reason is that no eurozone country missed payments and only two countries, Greece and Cyprus, restructured their debt. They did so preemptively and without missing payments. Thus, despite a rapid surge in sovereign bond yields in the eurozone periphery, there was no payment default. Such an outcome is not without precedent. It is reminiscent of several historical episodes as well as recent emerging-market crises, in which governments avoided default and instead serviced their debt in full, despite rapidly increasing bond yields (e.g., Mexico in 1994/95, Brazil in 1998 and 2001, Turkey in 2001, and the Philippines in 1998). Using 150 years of data, we document that "debt crises without default" are not new, but have become the new normal since the 1990s. In the past two decades, only about $20 \%$ of episodes with severe debt distress ended up in a sovereign default.

Section 4 explores why sovereign debt crises are costly. Theoretical models typically assume that defaults give rise to "output costs," implying a decline in GDP during default. Until 
recently, however, the literature had been rather silent on the underlying microeconomic reasons for these output costs. Moreover, the literature had difficulty explaining why GDP declined so strongly in Greece, Portugal, or Spain in 2010-12 even though there was no payment default in these countries. Recent theoretical and empirical contributions address both issues by examining specific channels of how sovereign risk (a collapse in sovereign bond prices, rather than an outright default) is transmitted to banks, households, and firms, resulting in less investment and lower welfare.

The feedback between distressed banks and fiscally distressed governments is explored in more depth in Section 5. Sovereign-bank linkages during the crisis have become known as "doom loops," and these motivated an entirely new area of research. We first describe the literature that examines how "doom loops" emerge and how they can amplify economic downturns. We then draw on long-run data to explore the history of sovereign-bank "doom loops" over the past 200 years. We find that "doom loops" are by no means a new phenomenon, but they have become much more prevalent. We document nine “doom loops” prior to World War II, and a further 13 in emerging markets since the 1980s. We speculate that, in contrast to the past, policy makers today perceive them as critical, because recent crises have occurred in highly financialized economies, and because governments, banks, and their regulatory agencies have become more intertwined.

Another notable feature of the eurozone crisis was the debate about "self-fulfilling" crises and "multiple equilibria”. Ireland and Portugal, for example, experienced problems in refinancing existing debts, as bond yields surged rapidly. Some observers interpreted this as an expectations-driven panic. Section 6 explores the recent theoretical advances of modeling rollover risk, multiple equilibria, and self-fulfilling crises. We discuss how institutional constraints, such as Europe's monetary union, could have played a role in tipping countries into "bad equilibria" and whether self-fulfilling crises will be more prevalent the future.

Section 7 moves away from eurozone economies by taking a more global perspective. We describe what is possibly the most important shift in global sovereign debt markets: the boom in domestic debt issuance. Until the early 2000s, most emerging-market governments could not issue domestic debt at long maturities and low rates. Since then, however, local-currency and local-law bond issuances have grown substantially. We examine the rise of domestic-currency debt worldwide and the motives for issuing debt at home or abroad. We also discuss the issue of domestic defaults, which could gain relevance given the growing volumes of domestic debt.

Using the bailouts in the eurozone crisis as motivation, Section 8 examines the growth of official lending worldwide, meaning government-to-government loans and multilateral lending. We put the recent rise in official-to-official debt flows, including through China's Belt and Road initiative and central bank-to-central bank credit lines, into historical perspective and discuss the literature exploring the implications of official bailouts for private debt markets and the domestic economy. Overall, policy makers appear to have become more averse to defaulting 
compared to the past, perhaps due to the increased risk of doom-loops, cross-border crisis spillovers, and self-fulfilling crisis dynamics.

Section 9 then examines the legal environment under which global sovereign debt issuance now operates and why it has become more challenging to restructure sovereign debt and negotiate debt relief with private creditors in an ad hoc manner. We discuss research on the rise of creditor litigation in London and New York as an increasingly important "enforcement technology." We also focus on the "holdout problem" - when groups of creditors refuse to participate in a negotiated restructuring - as happened for the English-law bonds in Greece's 2012 debt exchange or after Argentina's 2001 default. These developments appear to have strengthened the hand of creditors and raised the cost of default for debtors.

\section{The return of debt problems in advanced economies}

The wave of defaults in the 1980s triggered a large body of work on sovereign lending in lowand middle-income economies and default involving international banks. ${ }^{4}$ In the wake of the Brady deals, countries such as Argentina, Mexico, Russia, and Ecuador returned to bond-based borrowing in the 1990s and 2000s, and research accordingly shifted its focus toward studying sovereign bond markets and default in emerging markets.

Research on advanced-country debt also flourished, but it largely abstracted from aspects of sovereign risk and default. ${ }^{5}$ Instead, the emphasis was on fiscal policy, optimal debt management, and deficit spending (see e.g., Barro 1979, Alesina and Tabellini 1990, Bohn 1998, Alesina and Passalacqua 2016). The outbreak of the 2007-8 global financial crisis and the subsequent sovereign debt crisis involving high-income countries in Europe was a striking development that, again, shifted research in important ways, notably toward studying default risk in advanced or high-income economies. Ang and Longstaff (2013) and Chernov, Schmid, and Schneider (forthcoming), for example, study default risk in the United States, a country whose bonds have been regarded as "riskless" for much of the $20^{\text {th }}$ century.

\section{1. "Advanced countries do not default"}

The fact that few studies examined default risk in advanced or "leading" economies is unsurprising. Since World War II, no advanced country had entered a debt crisis, in contrast to the large number of defaults in the developing world. The view that advanced countries "do not default” gained currency after World War II (as described in Reinhart, Reinhart, and Rogoff 2015), and the notion even survived in the midst of the eurozone crisis - when the IMF issued a policy paper entitled "Default in Today's Advanced Economies: Unnecessary, Undesirable, and Unlikely” (Cottarelli et al. 2010). Public debt levels in advanced economies declined during

\footnotetext{
${ }^{4}$ See Eaton and Fernandez (1995) and Tomz and Wright (2013) for an empirical survey.

${ }^{5}$ As stated in the introduction, by advanced countries we refer to industrialized economies. See Footnote 4.
} 
the 1960s and 1970s and, despite an increase in the 1980s and 1990s, were still in line with historical averages (see Figure 3).

Advanced countries, ceteris paribus, were regarded as more resilient, owing to their more diversified economies (e.g., less reliance on commodity exports), more developed institutions, more resources to tax, and greater "state capacity." In line with this, Reinhart, Rogoff, and Savastono (2003) showed that advanced countries can sustain higher levels of debt and are less likely to default in the wake of adverse shocks. Reinhart, Rogoff, and Savastono (2003) in part, attribute this higher "debt tolerance" to better institutions for economic and crisis management (in line with North and Weingast 1989 and Acemoglu et al 2003). ${ }^{6}$ For example, some have argued that powerful central banks, such as the ECB, are important pillars of crisis management (e.g. Martin and Philippon 2017). It has also been argued that advanced countries benefit from having traditionally issued most of their debt in domestic currency and under domestic law (see Section 8). ${ }^{7}$ Indeed, once domestic debt and default are accounted for, the advanced economies appear somewhat less “debt tolerant” (Reinhart and Rogoff 2011b).

Figure 1 puts recent experiences in a long-run perspective. Advanced-country default is not new, historically, as documented by Suter (1992), Reinhart and Rogoff (2009) and Meyer, Reinhart, and Trebesch (2019). For example, the kings of France were serial defaulters between 1500 and 1800 . In the $19^{\text {th }}$ century, the first wave of advanced-country defaults occurred during the Napoleonic wars, when Austria, France, the Netherlands, Prussia, and Sweden, among others, ceased payments on their external debts (see Figure 1). The remainder of the $19^{\text {th }}$ century was dominated by defaults in Latin America and other developing countries, even though Spain, Portugal, and Austria defaulted repeatedly as well.

Advanced economies once again became the epicenter of international sovereign debt problems after WWI, particularly in Europe, due to the large-scale bilateral official loans extended between governments during and after the war. The so-called "war debt question" dominated international headlines and international economic conferences throughout the 1920s and only came to an end in 1934. In that year, all main European debtor countries, except Finland, defaulted unilaterally on their US and the UK debt obligations (Moulton and Pasvolsky 1932, Lloyd 1934, Reinhart and Trebesch 2016a, Hall et al. 2019).

During the interwar era, several advanced countries also defaulted on their debt to private creditors (e.g., Eichengreen and Portes 1986, 1989). In particular, the United States' abrogation of the gold clause in 1933 and Germany's sovereign debt default have received renewed attention recently (Edwards, Longstaff, and Marin 2015, Edwards 2018, Galofré-Vilà, et al. 2019, Straumann 2019). Dozens of lesser-known restructurings and debt “conversions” were also arranged with domestic creditors during the 1930s (Reinhart and Rogoff 2015, Meyer

\footnotetext{
${ }^{6}$ On the importance of institutions for sovereign risk and default, see Schultz and Weingast (2003), Van Rijckeghem and Weder (2009), Kohlscheen (2007) and Trebesch (2019).

${ }^{7}$ Some also argue that advanced countries have more to lose from a default, mainly due to high costs to their reputation (e.g. Phan and Wright 2019), which serves to constrain their behavior.
} 
2021). In addition, the governments of Germany, Italy, and Japan were in default on their external debts during World War II. These defaults ended with a series of restructurings in the late 1940s and 1950s, most prominently in the London agreement of 1953, which settled Germany's debts to private and official creditors. After the war, defaults became a rarity in advanced economies.

Figure 1: Defaults in advanced and emerging economies, external private debt, 1800-2015

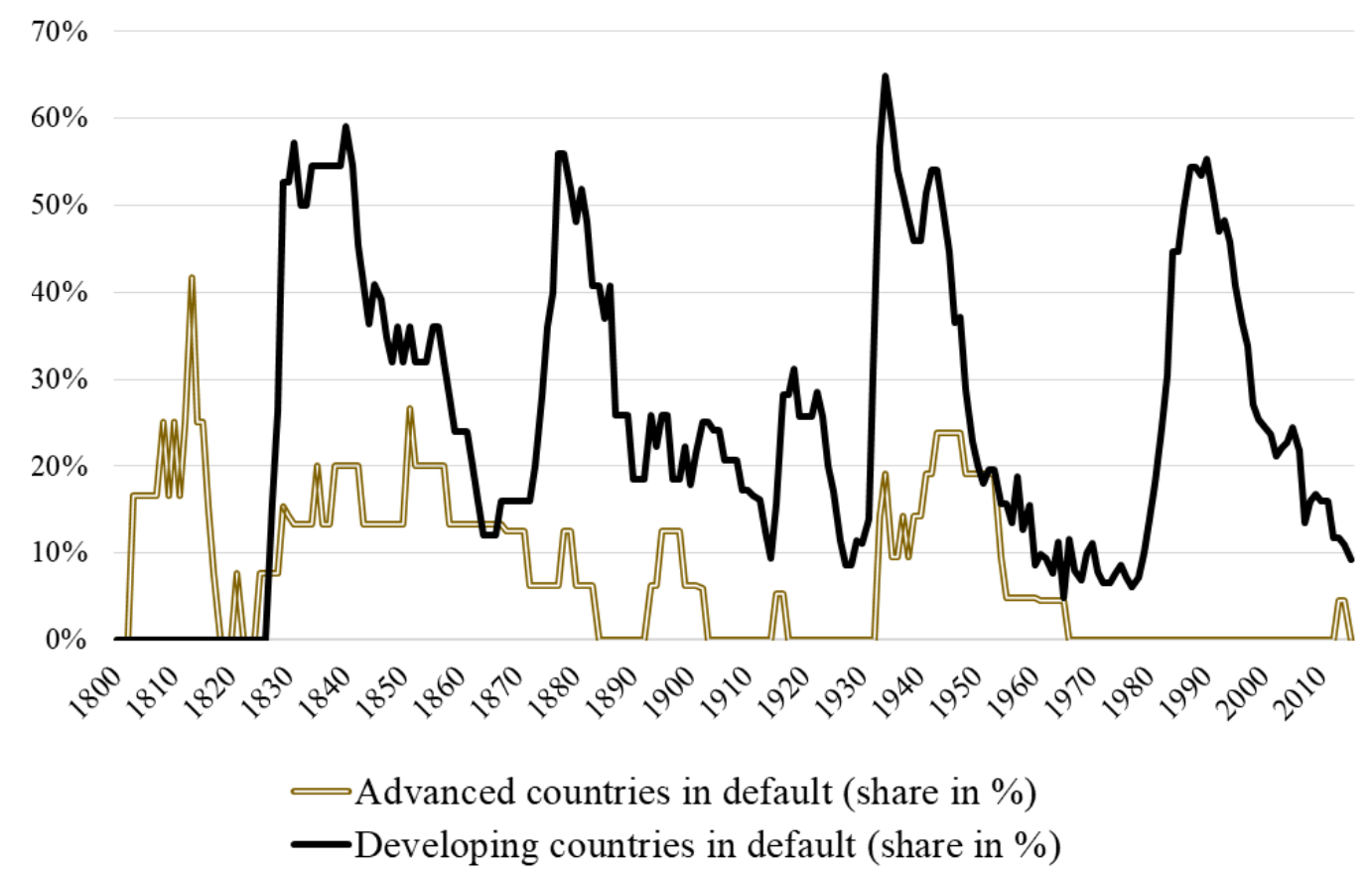

Note: Data and sample of independent countries from Reinhart and Rogoff (2009).

Greece's fiscal crisis brought concerns about advanced-country defaults back with a bang. Greek sovereign bond yields shot up in 2010 and, after several rounds of international bailouts and large-scale ECB bond buying on secondary markets, Greece eventually announced that it would restructure its debt in the summer of 2011 (see Lane 2012). The bond exchange was completed in April 2012 and broke a record in terms of the amount of debt involved. The size of the circle around Greece in Figure 2 displays that its default was the largest of the past 200 years, even surpassing Russia's 1917 external default. When examining countries of similar size and levels of development, it also ranks among the restructurings with the highest creditor losses, or "haircuts".

Despite the sizable haircut, the restructuring of Greek debt turned out to be insufficient to quickly restore debt sustainability. One reason is that the restructuring came too late, after tens of billions worth of its bonds had been paid in full and on time to private investors in 2010 and 2011. ${ }^{8}$ Moreover, the private debt stocks that Greece owed were almost entirely replaced by

\footnotetext{
${ }^{8}$ A stock-taking policy report by the IMF (2013) suggests that the Greek experience is part of a larger trend, stating that "debt restructurings have often been too little and too late, thus failing to reestablish debt sustainability and market access in a durable way.”
} 
official debt claims, turning Greece's creditor structure upside down (see Section 8 and Zettelmeyer, Trebesch and Gulati 2013). Between 2010 and 2012, the total amount of Greek public debt outstanding did not decrease by much, but it had largely shifted from private to official hands and onto the balance sheets of European governments and the IMF. In addition, Greece’s per capita GDP decreased by more than $20 \%$.

Looking back, the experience shows just how large the fallout of a debt crisis in an industrialized country can be, despite the fact that Greece was a comparatively small economy, accounting for less than 3\% of eurozone GDP. A default by Italy or Spain would have been much more consequential. This is one explanation why ECB President Draghi reacted to a renewed rise in Italian and Spanish government bond yields in the summer of 2012 by announcing to do "whatever it takes" to save the eurozone, thereby bringing the crisis to an end (Brunnermeier and Reis 2019).

Figure 2: Haircuts in sovereign debt restructurings with foreign private creditors since 1815

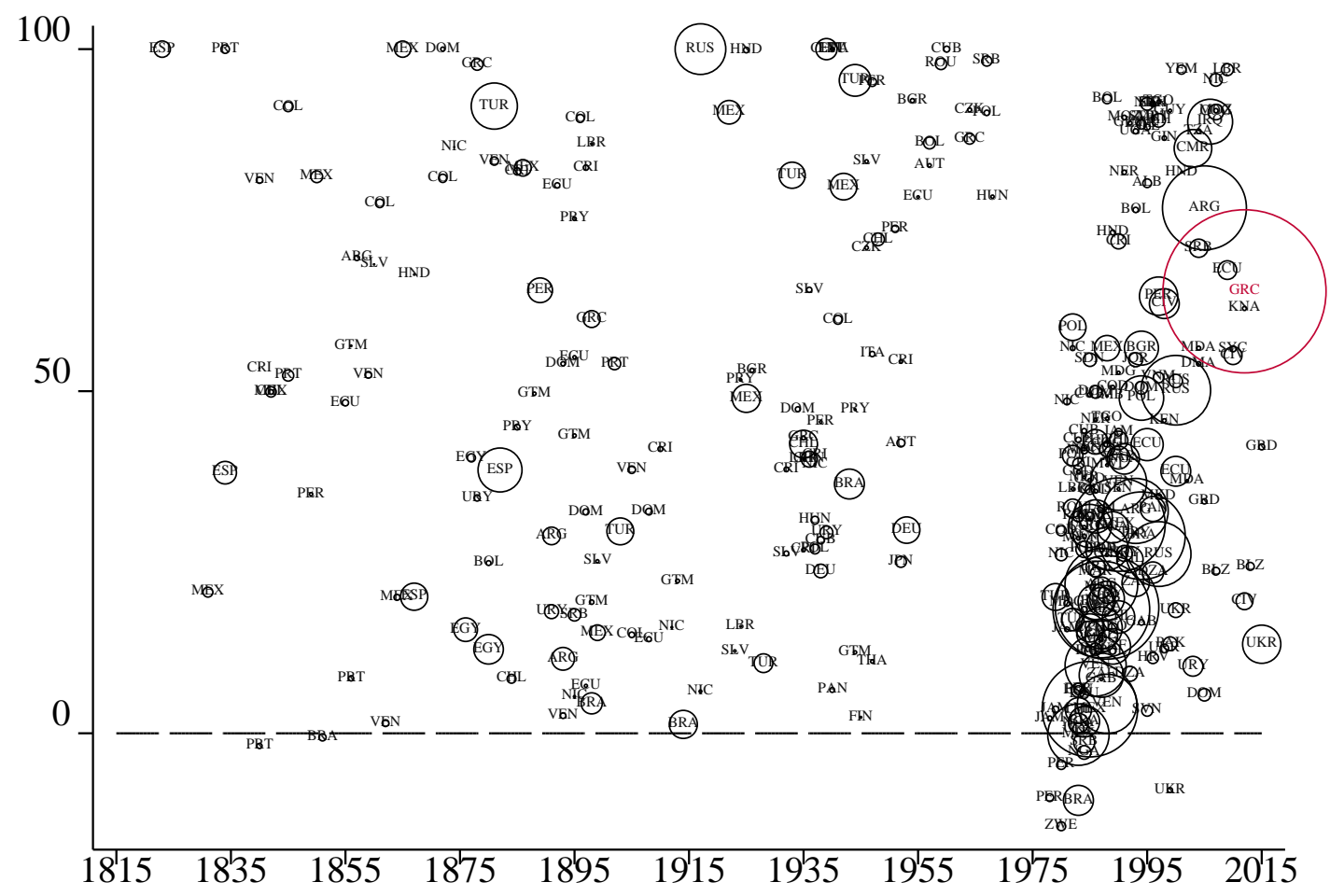

Note: Figure 2 from Meyer, Reinhart and Trebesch (2019). The figure shows the size of creditor losses or "haircuts" in sovereign debt restructurings with external banks and bondholders over the past 200 years (as a percent of debt affected). Haircut size is plotted on the vertical. The size of the circle captures the amount of debt involved, adjusted for inflation (based on constant 2009 USD). See Meyer, Reinhart and Trebesch (2019) and Cruces and Trebesch (2013) on data sources and on how haircuts are calculated, as well as for an explanation for why some haircuts are negative. The restructuring event marked in red is Greece 2012. 


\subsection{Always and ever: debt sustainability}

Greece's fiscal tragedy is just one in a long line of debt-sustainability crises. Long before the global financial crisis erupted, aging populations, low growth, and high levels of debt were leading to concerns about debt sustainability in advanced economies (Cecchetti, Mohanty, and Zampolli 2010, Yared 2019). For some policy makers, concern changed to worry when, between 2008 and 2018, debt-to-GDP ratios of advanced economies rose to levels not seen since World War II (Figure 3). And for some, worry has no doubt changed to alarm now that governments around the world have responded to the global pandemic of 2020-21 with massive fiscal support, leading to further increases in debt-to-GDP ratios. For example, the United States has seen its debt burden increase from about 60\% of GDP in 2005 to more than $120 \%$ of GDP in 2020.

Figure 3: Government debt to GDP: advanced vs. emerging economies, 1900-2020

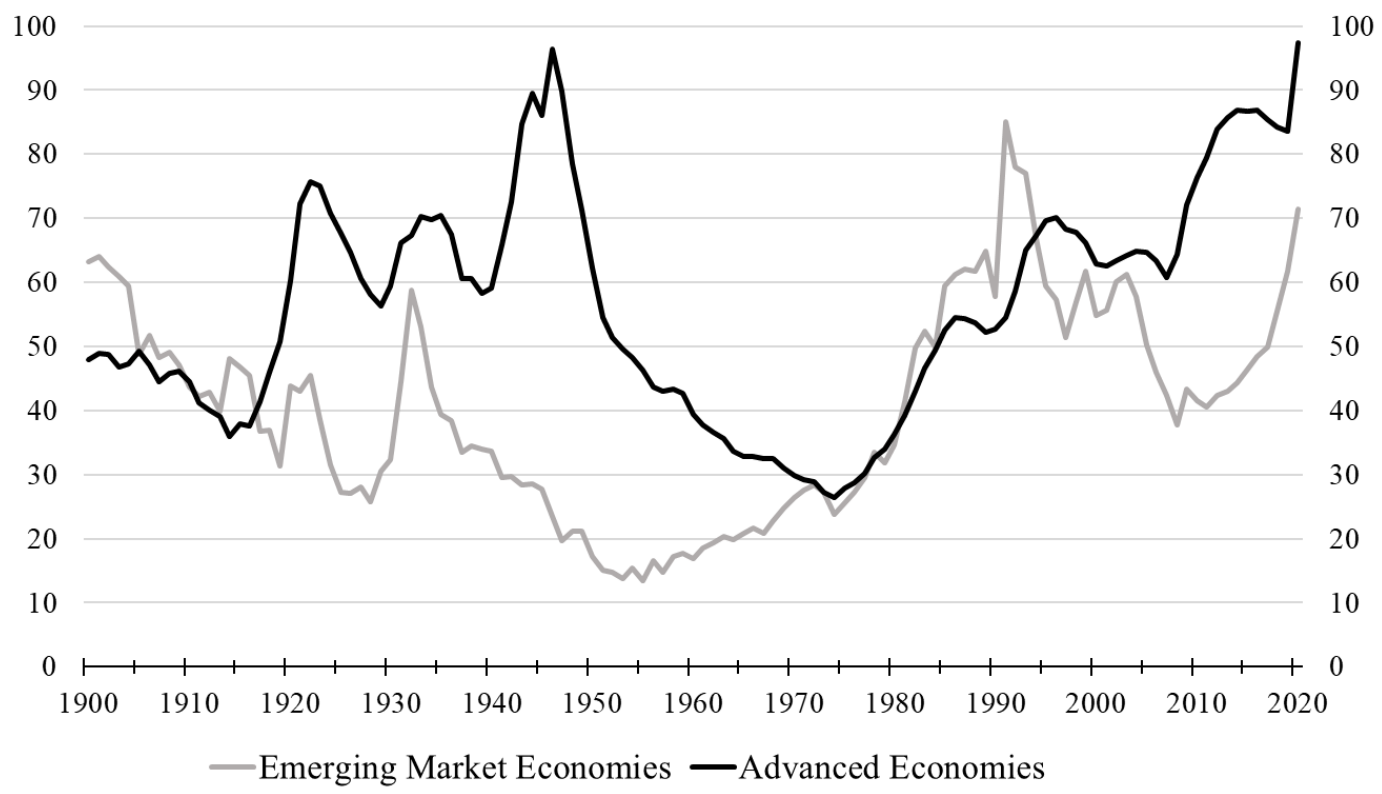

Note This graph shows the public debt/GDP ratio for 17 advanced economies and 43 emerging market economies since 1900 as unweighted country averages. The data for advanced economies is from Jordà, Schularick, and Taylor (2021) and that for emerging market economies from Reinhart and Rogoff (2009). For the 2010s, both series were updated using the IMF World Economic Outlook (WEO) database.

As debt sustainability issues have returned to vex advanced economies, it is not surprising that they have received renewed interest from researchers. One stream explores sovereign "debt overhang," or the implications of high debt levels for growth and investment. ${ }^{9}$ This work was sparked by an article of Reinhart and Rogoff (2010), which documented a negative correlation between debt levels and growth and argued that it was particularly problematic when public debt rose above $90 \%$ of GDP. More than two dozen papers have re-examined this issue, focusing on the choice of the debt thresholds, the potential endogeneity of debt, the role of

\footnotetext{
${ }^{9}$ Theory work on the topic goes back to Cohen and Sachs (1986) and Krugman (1988). More recently, see Aguiar, Amador, and Gopinath (2009).
} 
weighting and data coverage, and on heterogeneity across countries and time. ${ }^{10}$ Most of the follow-up studies also find a negative correlation between debt and growth. However, there is no consensus about the importance of a $90 \%$ threshold and on whether the relationship between these variables is causal (Checherita-Westphal and Rother 2012; Eberhardt and Presbitero 2015). A subsequent paper by Reinhart, Reinhart, and Rogoff (2012) expands their original dataset and finds that advanced countries that enter a high-debt spell (exceeding 90\% of GDP) typically stay above that threshold for two decades or more. At the same time, interest rates often remain low or decline during such spells, as demonstrated by the current situation in Japan or Southern Europe where high debt levels coincide with low sovereign bond yields.

A second area of research focuses on debt sustainability in advanced economies. In comparison to earlier approaches (e.g. Blanchard 1990), the new literature introduces uncertainty, examines non-linearities, and has a more quantitative focus. For example, Ghosh et al. (2013) build on the "fiscal reaction function" approach of Bohn (1998) to estimate "fiscal space," defined as the distance between a country's current debt level and its estimated "debt limit," when debt solvency and repayment are no longer assured. The estimated debt limits differ notably across 23 advanced economies, ranging between 150 and 250\% of GDP (see also Mendoza and Ostry 2008). Another example of work in this area is Collard, Habib, and Rochet (2015). They find a large variation in sustainable debt limits across the OECD, with some countries close to hitting their "maximum sustainable debt ratio." Another branch explores debt sustainability in the setting of dynamic general equilibrium models (e.g., D’Erasmo, Mendoza, and Zhang 2016, Bi 2012). Many recent analyses of debt sustainability share a commonality in that they have a nonlinear relationship between debt levels and sovereign risk premia. Once public debt passes a certain (country-specific) upper threshold, interest rates increase rapidly, so that debt suddenly becomes unsustainable. This relates to the literature on self-fulfilling debt crises, which we discuss in Section 6.

The low-interest-rate environment (with current rates hovering near zero) is a particularly salient aspect of the current discussion of fiscal sustainability in advanced economies. In his presidential lecture to the American Economic Association, Olivier Blanchard (2019) argued that "public debt may have no fiscal cost" if nominal interest rates (r) remain below the growth rate of nominal GDP (g), enabling governments to borrow and roll over their debts without needing to increase taxes in the future. Researchers are debating just how new and relevant the negative r-g is for debt sustainability. ${ }^{11}$ For example, Mehrotra and Sergeyev (2019) and Mauro and Zhou (2020) put the current situation in perspective, documenting that negative interestrate growth differentials are not unprecedented. Figure 4 confirms that, in historical perspective,

\footnotetext{
${ }^{10}$ For examples, see Kumar and Woo (2010), Herndon, Ash, and Pollin (2014), Cecchetti, Mohanty, and Zampolli (2011), and Panizza and Presbitero (2014).

${ }^{11}$ Cochrane (2021) concludes that $\mathrm{r}-\mathrm{g}$ is irrelevant for the current fiscal challenges faced by advanced countries such as the United States. He predicts that US debt/GDP dynamics in the next 20 years to be driven by the size of the primary surplus (deficit) rather than by variations in $r$-g. Relatedly, Reis (2021) emphasizes that the marginal product of capital (m) has stayed well above $g$ and $r$ and that this affects the way one should assess fiscal capacity.
} 
the current $r-g$ patterns are neither new nor particularly exceptional. Across advanced economies, $r-g$ was negative for most years since 1900 .

What makes today's situation unique is not the level of $r-g$, but rather the unusually low levels of $r$. For at least the last 150 years, nominal, sovereign bond yields have never fallen to zero or below zero in so many advanced economies simultaneously. Average interest rates and government bond yields are now at their lowest level in modern history, both in nominal and in real terms (Del Negro et al. 2019, Schmelzing 2019, Bauer and Rudebusch 2020). In recent years, the decline in sovereign bond yields accelerated further, despite the already high and rising public debt-to-GDP ratios. In the words of Reinhart, Reinhart, and Rogoff (2012), we are living in an era of high debts "without interest drama."

Figure 4: $\boldsymbol{r}-\boldsymbol{g}$ in advanced economies, 1900-2020

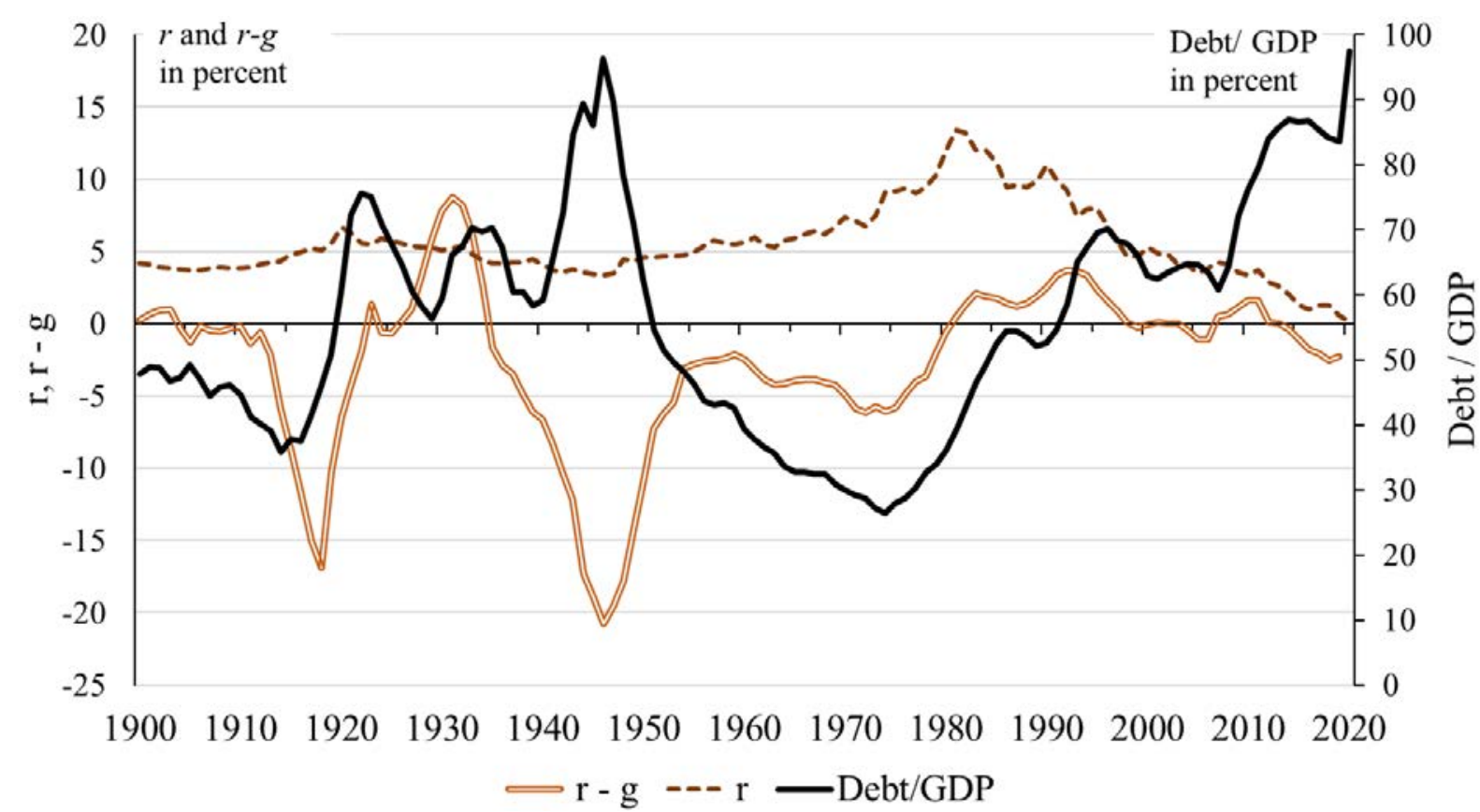

Notes: The figure plots the interest rate, $r$, the interest rate-growth differential $r$ - $g$, and the public debt-to-GDP ratio since 1900 as an unweighted average of 17 advanced economies. Data through 2017 are from Jordà, Schularick, and Taylor (2021), with $r$ being the nominal domestic long-term interest rate and $g$ the annual nominal growth rate of GDP. Because the $r-g$ differential is volatile, it is shown as five-year moving average. For 20172020, data on $r$ and $g$ are from OECD data and debt-GDP data are from IMF WEO.

Figure 5 shows that the decline in interest rates has helped to keep the fiscal costs of debt low. In the 2010s, the average fiscal cost for servicing the outstanding government debt stock fell well below 2\% of GDP annually in advanced economies. This contrasts starkly with the 1980s and 1990s, when debt servicing costs exceeded 4\% of GDP. In a long-run perspective, the high debt service burden and interest rates of the $80 \mathrm{~s}$ and $90 \mathrm{~s}$ look more like outliers than the historical norm. Given the unusually high interest burden, it is not surprise that this era saw a flurry of research and policy debates on debt and debt sustainability, with fiscal rules becoming a relevant policy tool (see Asatryan, Castellón, and Stratmann 2018). 
A more general insight from Figure 5 is that advanced-economy debt levels and debt-servicing costs have decoupled. Up until WWII, the debt level closely co-moved with the fiscal cost of debt, as measured by interest payments to GDP. Since the 1960s, however, the two times series no longer move in tandem. This decoupling of debt costs and debt levels makes it harder to predict the long-term consequences of today’s high and growing public debt stocks.

Figure 5: Debt servicing costs as a percent of GDP in advanced economies, 1900-2020

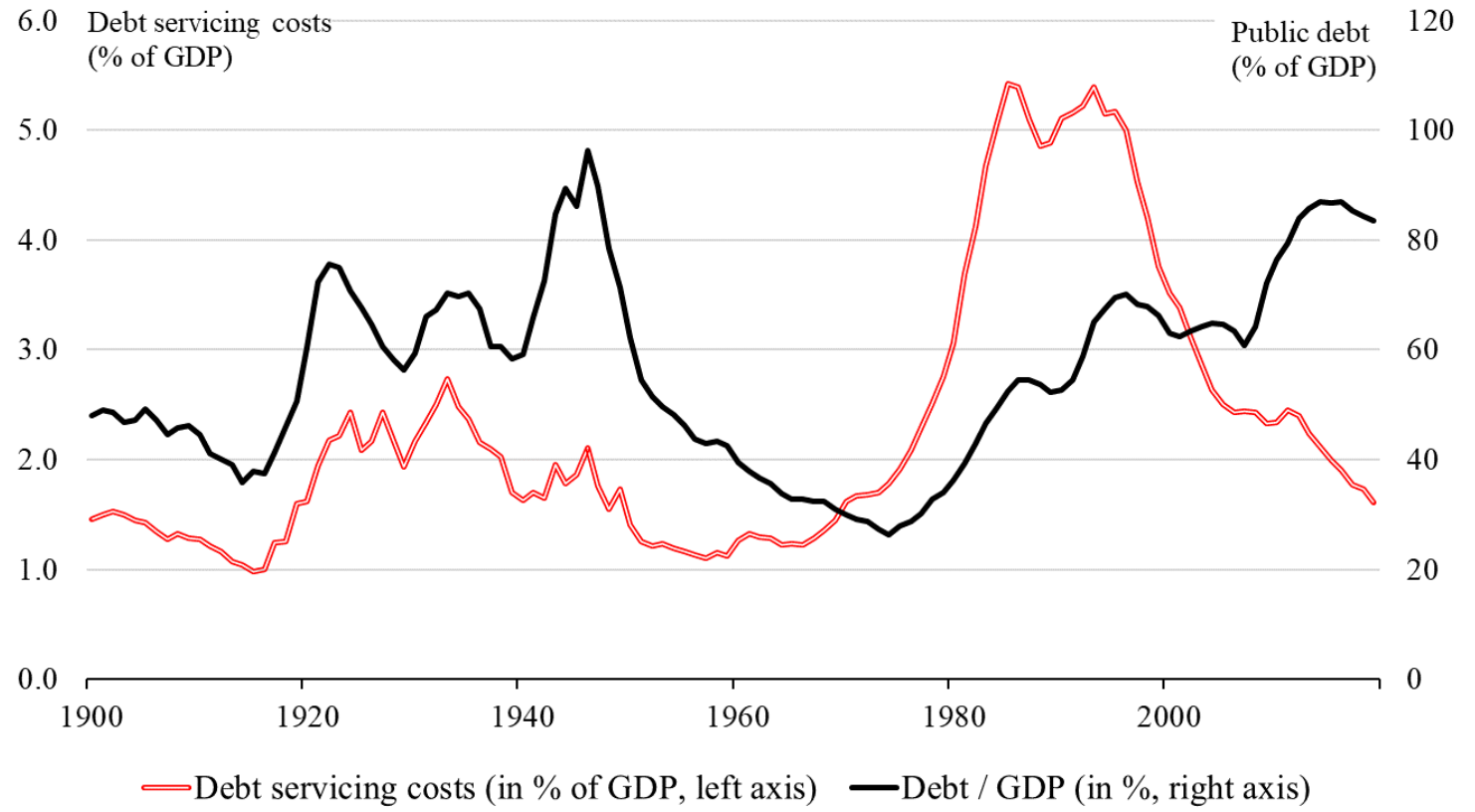

Notes: This graph shows the debt-servicing costs and public debt levels, both as ratio to GDP, for 17 advanced economies since 1900 as unweighted country averages. Debt servicing costs are from Mauro et al. (2013a) and calculated as the interest paid on public debt. The data for public debt/GDP are taken from Jordà, Schularick, and Taylor (2021). For the 2010s, debt/GDP is updated using the IMF WEO database and debt servicing costs using the World Bank IDS database.

Looking ahead, a central question is how interest rates and, consequently, debt service burdens will evolve. If interest rates in advanced economies stay low or even decline further, the next decades could look like the 2010s, with a combination of growing debt-to-GDP ratios, negative r-g, and comparatively low debt servicing costs. Indeed, one interpretation of Figures 4 and 5 is that we are moving back to the historical long-run equilibrium, with low and stable interest rates and yearly debt-servicing costs hovering around 2\% of GDP. The alternative scenario is a reversal of interest rates, such as in the 1970s, or a temporary yield spike as in the eurozone periphery in 2010-13. If that happens, the large, accumulated debt stocks could quickly morph into a new wave of debt distress and defaults. In that situation, much will depend on the behavior of central banks, as discussed in the next sub-section.

\subsection{Central banks have (again) become large holders of sovereign debt}

In the past three decades, central banks have become a dominant player in global sovereign debt. One reason for this development is the financial crisis of 2008 and the eurozone crisis that followed. Quantitative easing policies in the US, the UK, and Japan, as well as crisis-related 
bond purchase programs (e.g. by the ECB) meant that sovereign bonds worth trillions of US dollars moved from the balance sheets of private investors to those of central banks (see D’Amico et al. 2012 and Krishnamurthy, Nagel, and Vissing-Jorgensen 2018). On average, central-bank holdings of advanced-economy sovereign debt rose from just $10 \%$ in 2004 to more than $30 \%$ by the end of 2019, making central banks the single most important sovereign creditor (Arslanalp and Tsuda 2012). Another important driver for the growing creditor role of central banks has been reserve accumulation and large-scale bond purchases by emerging markets, a trend that accelerated after the Asian crisis of 1997-8 and that was further fueled by the rise of China as a capital exporter (see Gourinchas and Jeanne 2013 and Alfaro, Kalemli-Ozcan, and Volosovych 2014).

During the global pandemic, central banks have only become more influential for sovereign debt markets worldwide, with a further wave of bond buying since March 2020. In effect, during crises, central banks have turned into "the buyer of last resort", with large effects on bond yields, government market access, and debt sustainability (Acharya, Pierret and Steffen 2018).

Figure 6: Central bank holdings of governments debt (as \% of GDP, 1870-2016)

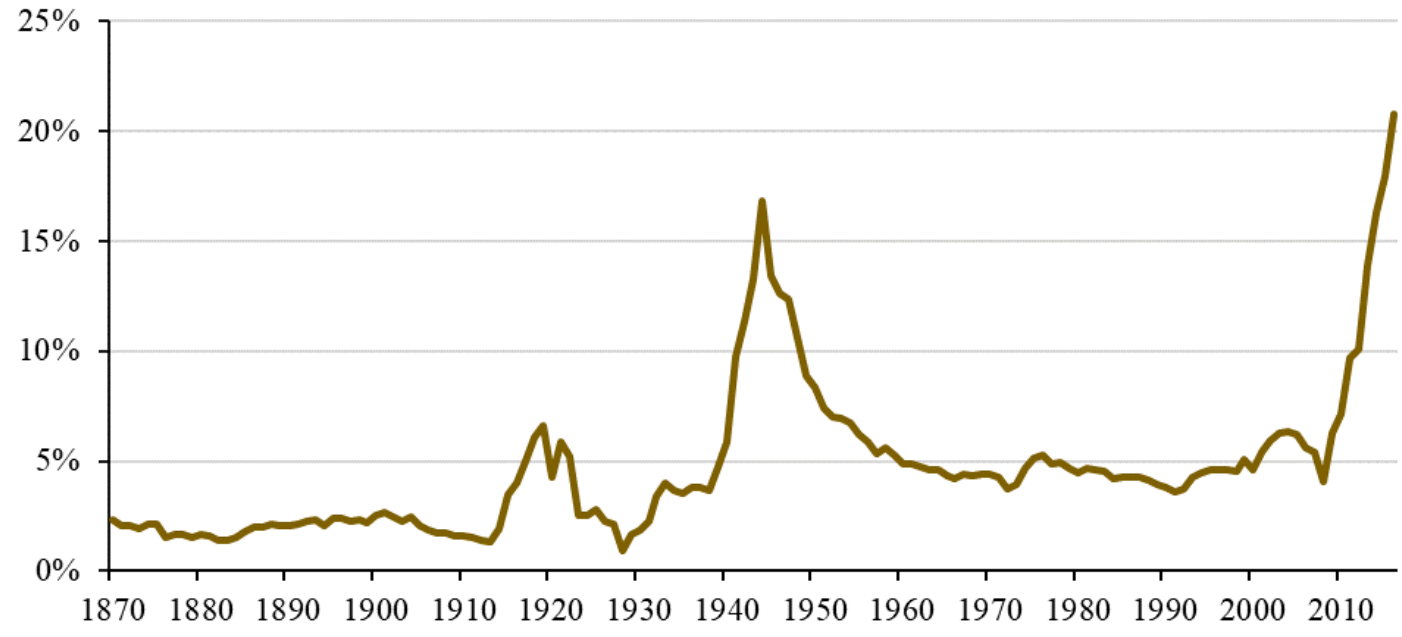

Note: Data on sovereign debt holdings by central banks by Ferguson, Schaab, and Schularick (2015, 2020). The 12 countries included in the sample are Australia, Canada, Finland, France, Germany, Italy, Japan, Norway, Sweden, Switzerland, UK, US.

Figure 6 shows that these developments are reminiscent of the second quarter of the 20th century. During the Great Depression, advanced-economy central banks already played the role of "buyer of last resort" - helping to finance the record sovereign debt issuance by Great Britain, France, the US and other countries (Ferguson, Schaab, and Schularick 2015). The share of advanced-economy government debt held by domestic central banks increased dramatically, reaching its apex around 1945. Today, after the 2008 crisis and the global pandemic shock, we have clearly surpassed this previous historical peak. In sum, central banks have again become a dominant financier of governments worldwide. Whether and when this trend will reverse again is a decisive question for sovereign debt markets in the coming decades. 


\section{Debt crises without default}

The eurozone crisis is widely regarded as a sovereign debt crisis (e.g., Lane 2012, Brunnermeier and Reis 2019). However, according to the prevalent definition of debt crises, it was not. As discussed by Ams et al. (2019), researchers and rating agencies typically identify a sovereign default as involving either (i) missed payments (a legal default) and/or (ii) a debt restructuring at terms that are worse than the original terms, implying creditor losses ("haircuts") and/or coercion imposed by the sovereign.

Defining defaults as either missed payments or distressed restructurings has the advantage of being easy to apply across countries and historical eras, including for crises in ancient times (see Reinhart and Rogoff 2009). It is also worth noting that many defaults are partial, meaning that they affect only some parts of the total public debt, and that many restructurings occur preemptively, without missing payments. This is true for recent decades (see Asonuma and Trebesch 2016, Arellano, Mateos-Planas, and Ríos-Rull 2019, Schlegl, Trebesch, and Wright 2019) as well as historically, e.g. the partial defaults under Philipp II (Conklin 1998, Drelichman and Voth 2014, Álvarez-Nogal and Chamley 2014).

The traditional way of defining default, however, fails to classify most eurozone crisis countries as being in crisis. Only Greece and Cyprus met the criteria, and only for a single year each, due to their debt restructurings in 2012 and 2013, respectively. ${ }^{12}$ No other European government defaulted, despite very high bond yields, very high credit default swap (CDS) premia, and a loss of market access, most notably in Portugal and Ireland. Put differently, Europe went through a deep debt crisis, but bondholders continued to receive payments in full and on time. In a similar vein, several prominent emerging market crises, such as in Mexico (1994/95), Thailand (1997/98), Brazil (1999 and 2002), Turkey (2001), or Russia (2015) did not result in a default or restructuring of external debt. ${ }^{13}$

We term these events as "sovereign debt crises without default." These are crises with high sovereign bond yields and debt rollover problems, but no missed payments or legal default. Pescatori and Sy (2007) argue that default events are no longer a reliable indicator of debtservicing difficulties. They therefore propose to broaden the definition of debt crises to include episodes with yield spreads above 1000 basis points, which they refer to as a "psychological barrier by market participants.” Broner, Lorenzoni, and Schmukler (2013) and Aguiar et al. (2016) follow a similar route, identifying debt crises as episodes with strong increases in bond

\footnotetext{
${ }^{12}$ Even these two countries did not miss a single payment because the debt exchanges were arranged preemptively (Asonuma and Trebesch 2016, Zettelmeyer, Trebesch, and Gulati 2013).

${ }^{13}$ Over the past 20 years, the share of countries in default have decreased notably, despite two waves of debt servicing problems in emerging markets (1998-2002 and around 2008), as well as in 2010-2012 in Europe. Roughly 25 sovereign defaults and restructuring episodes have occurred since the 2000s in comparison to approximately 100 such events in the 1980s alone (Meyer, Reinhart, and Trebesch 2019). In addition, about half of the recent sovereign bond restructurings were preemptive in nature, defined as debt exchanges before payments are missed (Asonuma and Trebesch 2016).
} 
yields quarter-on-quarter or what some have called "spread crises" or "spread spikes" (Krishnamurthy and Muir 2017).

How frequent are debt crises without default in advanced countries and emerging markets? And are they really a recent phenomenon? To address these questions, we use the dataset of Meyer, Reinhart, and Trebesch (2019), which covers historical foreign-currency bonds, and combine it with modern-era yield data from Thomson Reuters Eikon (domestic currency sovereign bonds from advanced countries) and from JP Morgan EMBIG (emerging market foreign-currency bonds). Spreads are computed by subtracting a proxy for "safe assets", i.e. the UK and US longterm bond yield until WWII (using the Meyer, Reinhart, and Trebesch 2019 data), and the US and German Bund bond yield in the modern (post-1995) period. ${ }^{14}$ We then classify periods with high and/or rapidly increasing bond yield spreads and match them with data on outright defaults and restructurings from Reinhart and Rogoff (2009) and Meyer et al. (2019). ${ }^{15}$ The sample starts in 1870, when bond yield spreads become available for more than 20 countries. ${ }^{16}$

"Spread crises" are identified by combining the methodology by Pescatori and Sy (2007), who focus on the widely used 1000 basis point threshold, and by Aguiar et al. (2016) and Krishnamurthy and Muir (2017), who focus on rapid spread increases. More specifically, we identify a crisis if either the spread surpasses 1000 basis points in a given quarter and/or if spreads increase very rapidly, defined as a spread increase that is at least in the 99th percentile of quarterly spread increases. ${ }^{17}$ The "spread crisis" ends if the spread falls below its pre-crisis average. ${ }^{18}$

With this approach we identify 97 "spread crises" between 1870 and 2014. Of these, 53 cases (55\%) coincide with an outright default, while 44 cases do not, and can thus be termed "debt crises without default”. Interestingly, however, the share of debt crises with default has been declining notably since 1870, both in advanced and emerging economies. This can be seen in

\footnotetext{
${ }^{14}$ In the post-1995 high-income sample, we use US yields to compute bond spreads for Australia, Canada, Japan, New Zealand, Norway, Singapore and Switzerland, and German Bund yields for EU members, namely Austria, Belgium, Czech Republic, Greece, Finland, France, Ireland, Italy, Portugal, Sweden and Spain.

${ }^{15}$ Specifically, our sample includes the following 45 countries. Argentina, Australia, Austria, Belgium, Bulgaria, Brazil, Canada, Switzerland, Chile, China, Colombia, Costa Rica, Czech Rep. (only modern), Germany (only historic), Denmark (only historic), Ecuador, Egypt, Spain, Estonia (only historic), Finland, France, Greece, Grenada (only historic), Hungary, India (only historic), Ireland, Italy, Japan, Mexico, Norway, New Zealand, Panama, Peru, Philippines (only modern), Poland, Portugal, Russia, Singapore, Sweden, Thailand, Turkey, Ukraine (only modern), Uruguay, Venezuela, South Africa.

${ }^{16}$ We include all sovereigns with at least 10 years of bond yield data (min 20 years in the historical sample). The years 1946-1994 are excluded, since there was no liquid market for emerging market sovereign bonds.

17 The resulting threshold in the historical period (pre-WWII) is a quarter-on-quarter spread increase of 451 basis points. In the modern (post-1995) period the threshold is 378 basis points. Of course, crisis definitions based on "thresholds" are ex post and ad hoc and require that the data are driven by an objective and invariant probability distribution - something that may not hold over long sweeps of history as pointed out by Oosterlinck et. al. (2015), which is one reason why we allow our threshold to vary.

${ }^{18}$ To avoid excessively long crisis spells we add a one quarter standard deviation to the pre-crisis spread (using country-specific standard deviations) and use that as the exit threshold. Spread spikes that occur in the same year (four or less quarters apart) are combined into one crisis spell.
} 
Figure 7, which plots the fraction of "spread spikes" with and without default across eras for all countries combined. Before WWI, more than $80 \%$ of debt crises involved a default. This share fell during the interwar years and even more so during WWII, when half of the "spread spikes" saw a default. In the modern era, only about $25 \%$ of debt crises involve an outright payment default. When looking at advanced and emerging markets separately, the declining time trends look very similar. Before WWII, more than 70\% of “spread crises" in both advanced and emerging economies involved a default. This share has dropped in both country groups to around just $30 \%$ since the 1990 s.

Figure 7: Sovereign debt crises with and without default (share of events in \%)

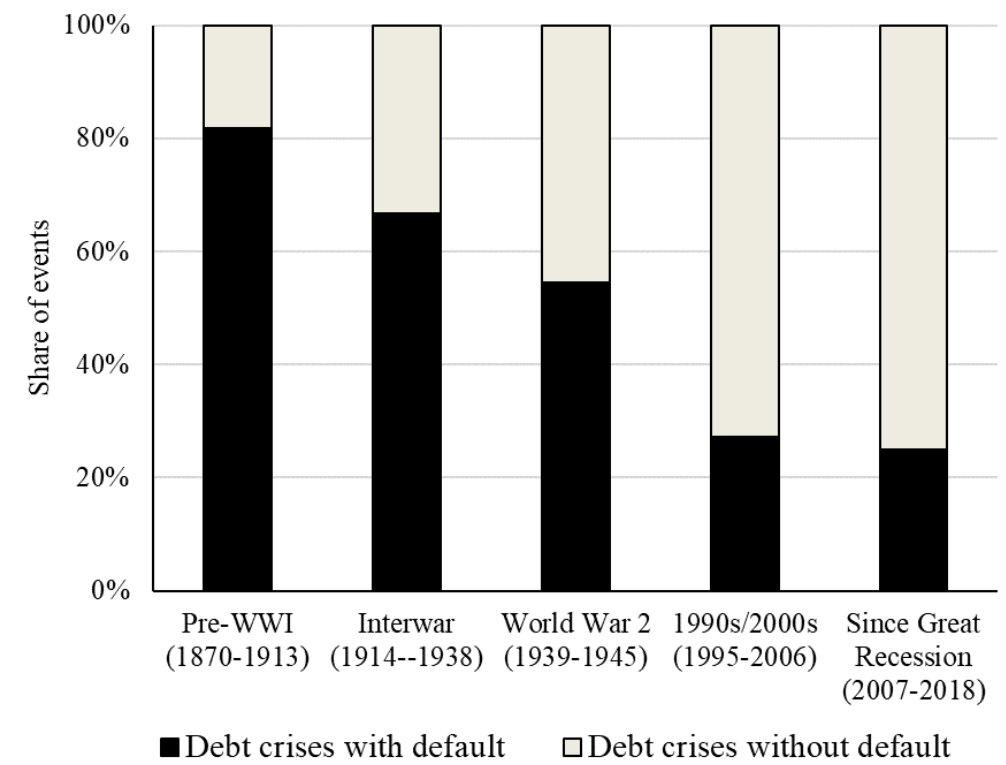

Note: Debt crises or "spread spikes" are measured by high or rapidly increasing sovereign bond yield spreads (see text for details). Defaults involve missed payments and/or restructuring with creditor losses. The time trend looks very similar when plotting advanced and emerging economies separately.

As our results show, "debt crises without default" are by no means new, but they have become increasingly common since the 1990s. Figure 8 illustrates this by plotting sovereign bond yield spreads for selected cases. Historically, one of the rare examples of "debt crises without default" is Argentina during the belle époque (fiscal crisis of 1876) as well as during the 1930s (Great Depression), shown in Panel A. In both episodes, the country avoided defaulting despite severe distress.

Similarly, Panel B shows that Brazil, Mexico, and Venezuela went through periods of severe debt distress without defaulting in the 1990s and early 2000s, while Panel C focuses on the eurozone crisis. Despite quickly increasing bond spreads in 2010 and 2011, neither Portugal nor Ireland ended up defaulting.

The historical evidence thus suggests that the nature of sovereign debt crises has changed over the past 200 years. The probability of outright default has decreased while yield spikes without 
missed payments have become more frequent. Today, the large majority of debt distress spells end benignly for creditors, in the sense that the bonds continue to be serviced in full. More generally, Mauro, Sussman, and Yafeh (2002) find that the probability of sharp increases in bond spreads has gone up compared to the $19^{\text {th }}$ century, as has the co-movement of bond yields across countries. Put differently, the "global factor" and contagion in sovereign risk pricing has become more important in recent decades, while country-specific fundamentals have become less so (see also González-Rozada and Yeyati 2008 and Longstaff et al. 2011).

Figure 8: Selected episodes of debt crises without default

Panel A: Argentina 1870-1945: three debt crises but only one default

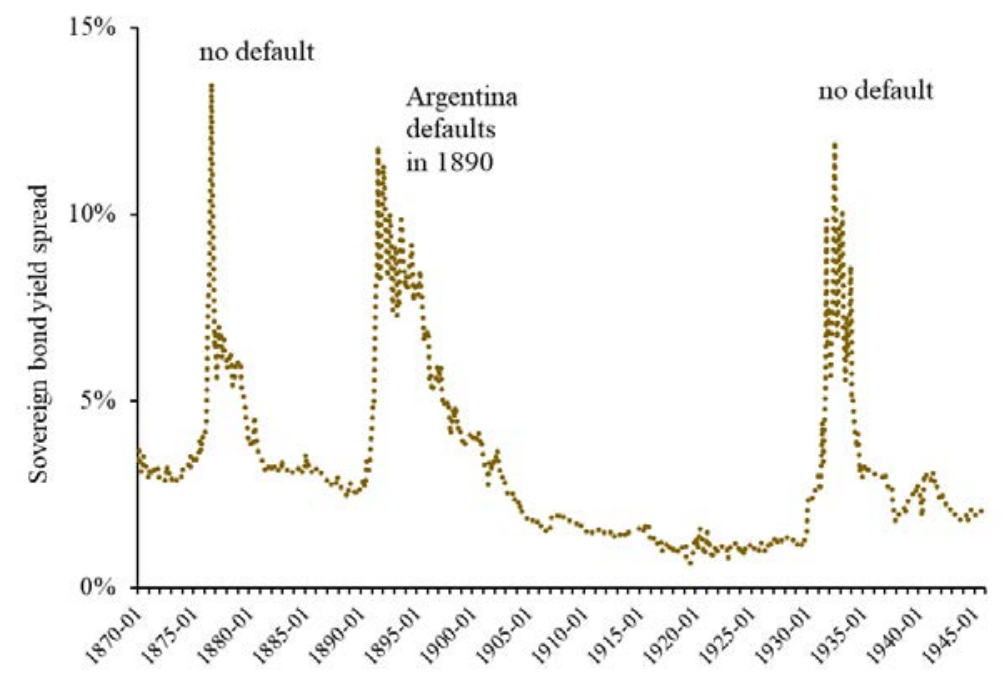

Panel B: Latin America in the 1990s: only Argentina defaults

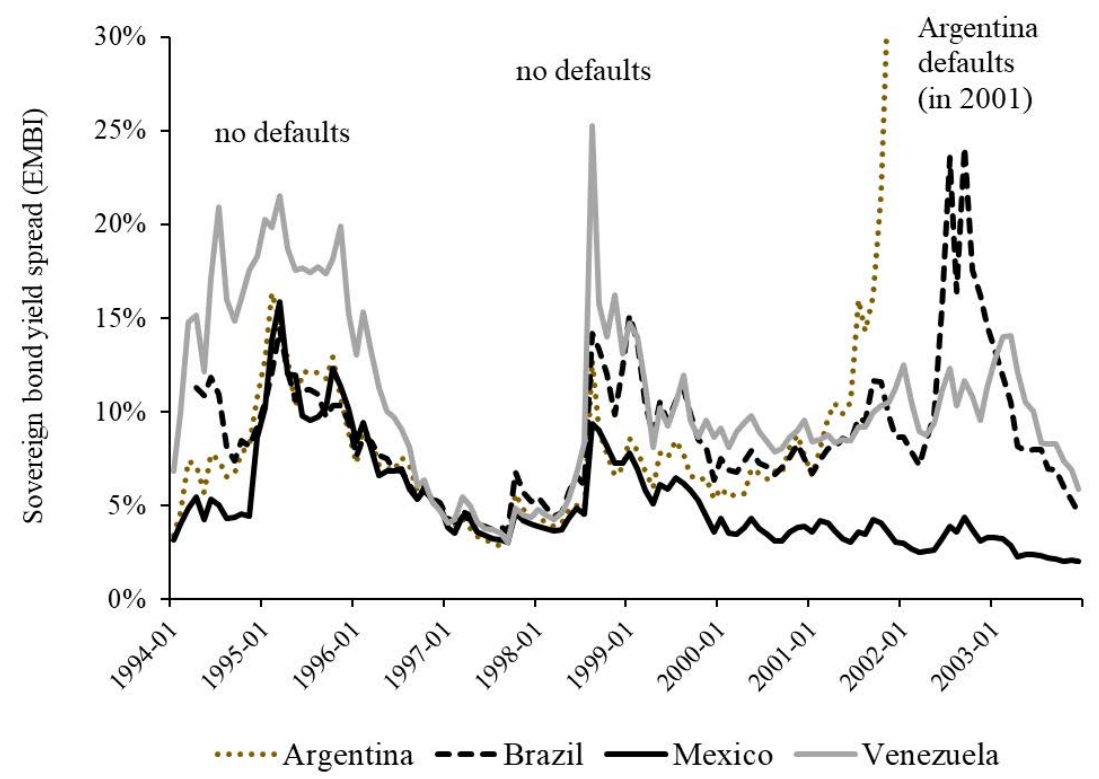


Panel C: Eurozone debt crisis: only Greece defaults

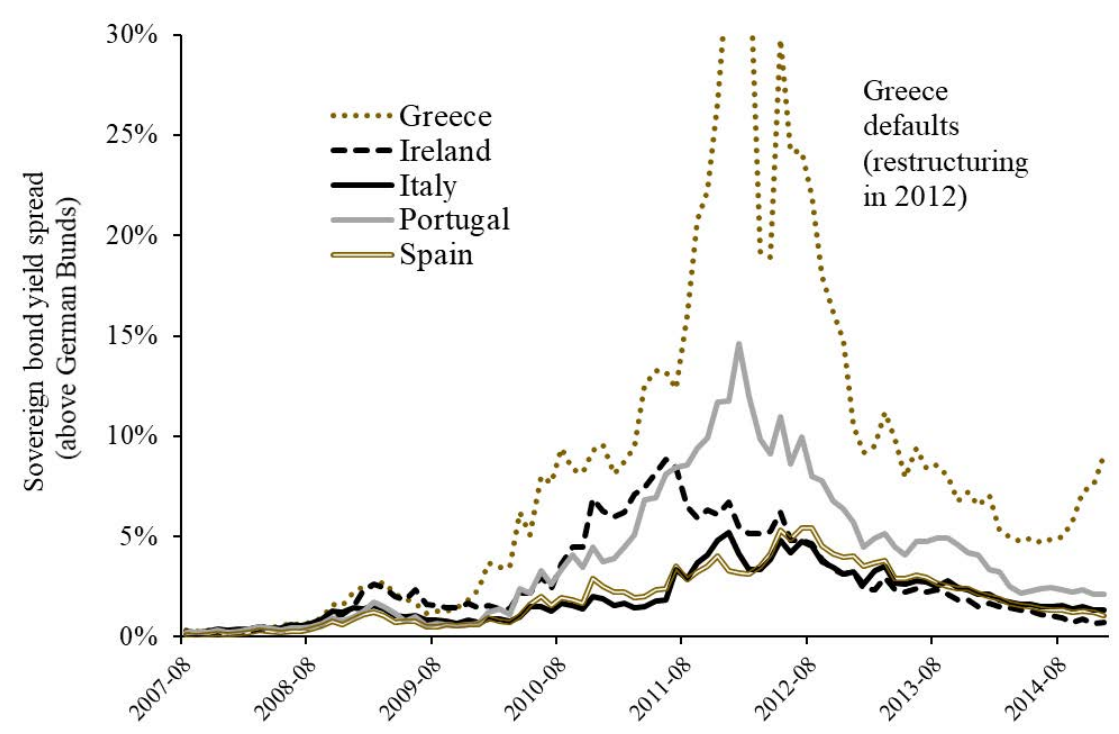

\section{The transmission of sovereign risk to firms and the macroeconomy}

The eurozone debt crisis also re-shaped how the field thinks about the consequences of sovereign risk and default. A new generation of sovereign debt models focuses on micro-level effects, in particular the costs borne by firms and households when sovereigns face debt distress. This body of work also draws attention to the central role of banks and financial markets for propagating sovereign default risk, including the feedback effect between sovereign credit and the financial sector, known as "doom loops." In this section, we focus on the propagation of sovereign risk to firms, households, and the macroeconomy. We then devote Section 5 to sovereign-bank linkages.

One of the oldest puzzles regarding sovereign debt is why countries ever bother to pay back their loans to foreign creditors, since, unlike for corporations, enforcement is cumbersome, and no insolvency regime exists. Over the past four decades, the two main explanations as to what motivates countries to service their debts are "reputation" and "sanctions." According to the first view, a default hurts the government's reputation and thus implies a loss of access to international capital markets as well as higher borrowing costs (as in Eaton and Gersovitz 1981, Cole, Dow, and English 1995). In addition, defaults can trigger sanctions of diplomatic, legal, or military nature, thereby impairing a country's ability to trade in international goods and capital markets (as in Bulow and Rogoff 1989a). There is some historical evidence for the operation of both channels. However, the fact that sovereigns can typically borrow again after a default, often at comparatively low rates, casts doubt on the notion that observed penalties or "pure reputational effects" are sufficient to discipline borrowers.

Starting with Aguiar and Gopinath (2006) and Arellano (2008), a new strand of literature developed quantitative models that could match a set of "stylized facts" on sovereign debt and 
default (see Aguiar and Amador 2014 for a survey). Many of these models feature two types of exogenous default costs that help to generate equilibrium levels of debt that are more in line with what is observed in the data. First, the classic "market exclusion" assumption in the tradition of Eaton and Gersovitz (1981), according to which sovereigns cannot access international credit markets when they are in default. This assumption is backed by a large empirical literature (summarized in Panizza et al. 2009), although the exclusion effect appears to fade quickly after defaults are settled (e.g., Gelos, Sahay, and Sandleris 2011, Cruces and Trebesch 2013).

A second widespread assumption in modern theoretical work on sovereign debt is that there is an exogenous "output cost" to default. Empirical research provides support for the notion that sovereign defaults cause sizable output losses, estimated in the range of 1-4 percentage points of real GDP per capita growth in the first few years post-default (e.g. Borenzstein and Panizza 2009, Furceri and Zdzienicka 2012, Trebesch and Zabel 2017, Kuvshinov and Zimmermann 2019). ${ }^{19}$ Moreover, there is growing evidence that the cost of default depends on the characteristics of the debt crisis. Defaults involving high haircuts, long negotiation delays, and "coercive” government measures (such as a unilateral payment suspension) are associated with higher output losses and increased subsequent borrowing costs. ${ }^{20}$

However, this literature does not explore the underlying reasons why sovereign defaults lead to a decline in output, nor does it try to model the cost of sovereign risk in the absence of default, as observed during the eurozone debt crisis. To grapple with these features, researchers have been examining the microeconomic channels through which sovereign default risk can lead to macroeconomic effects. For example, Mendoza and Yue (2012) develop a general equilibrium default model in which firms rely on external finance to purchase imported production inputs from abroad. Building on Eaton and Gersovitz (1981), both the government and domestic firms are excluded from international capital markets after a sovereign default. In each period, the sovereign weighs the cost of this market exclusion and lost output versus the benefit of not servicing the debt. In equilibrium, if the sovereign chooses to default, firms cannot finance their working capital from abroad, forcing them to shift to domestic inputs and other imperfect substitutes, and resulting in efficiency losses and a decline in output. This transmission mechanism, from sovereign risk to corporate financing, explains why defaults are associated with deep recessions in the model.

More recent studies draw on the eurozone debt crisis to unearth the mechanisms explaining the decline in output. Corsetti et al. (2012) use a New-Keynesian model to show that sovereign risk affects corporate borrowing conditions through a fiscal channel, as higher sovereign bond yields

\footnotetext{
${ }^{19}$ Levy Yeyati and Panizza (2011) show that most of the output contraction occurs in the quarters prior to a sovereign credit event, suggesting that it is mostly the expectation of a default that drives the output losses and not the actual breach of contracts.

${ }^{20}$ See Cruces and Trebesch (2013), Trebesch and Zabel (2017), and Asonuma et al. (2019). For historical evidence see Catão and Mano (2017) and Esteves, Kenny, and Lennard (2021). These results have also motivated theory, such as the recent analysis of "hard” and "soft” defaults by Gordon and Guerron-Quintana (2019).
} 
result in a pessimistic shift in expectations about future tax hikes, social unrest, or tariff increases. The increased corporate funding costs then contribute to lower output and macroeconomic instability. ${ }^{21}$ Focusing on the case of Greece, Gourinchas, Philippon, and Vayanos (2017) similarly show that a sovereign-bond yield shock leads to contractionary fiscal policy, increasing the likelihood of loan defaults in the private sector and thereby resulting in higher corporate borrowing costs, less productive investment, and, in turn, lower output. In a similar vein, Arellano, Bai and Bocola (2019) combine a micro-founded general equilibrium model with a detailed firm- and bank-level empirical analysis. The model features heterogeneous firms and banks, and shows that a large increase in sovereign bond yields also affects corporate interest rates because banks that suffer losses on their government bond holdings tighten lending standards and ration credit. ${ }^{22}$ This pass-through of sovereign risk is larger for firms with large borrowing needs and for those more exposed to banks that hold many government bonds. These mechanisms are tested in a large cross-section of Italian banks and firms, with evidence for both channels. The empirical results are then used to estimate the model. They find that a 100-basis-point increase in sovereign bond yields increases corporate borrowing rates by 70 basis points, and results in a $0.7 \%$ decline in output, mostly due to the direct (firm borrowing) effect.

In the empirical literature, a large new body of work has emerged using novel datasets and methods to identify causal effects of sovereign-default risk on firms and the aggregate economy. The analysis by Hébert and Schreger (2017) is noteworthy since it is the first to make use of a natural experiment to identify the cost of sovereign default risk. They use data from Argentina to show that higher sovereign bond yields cause a decline in the stock price of Argentine firms. ${ }^{23}$ Specifically, the analysis exploits plausibly exogenous variation in Argentina's sovereign risk due to a series of New York court rulings in NML vs Argentina, which the media coined the "sovereign debt trial of the century" (see Section 9). The key identification assumption is that the judge's rulings contained relevant news that changed the probability of a sovereign default but did not affect domestic firms directly. They find that a 10-percentage point increase in default probability reduces the market value of Argentine firms by six percentage points, on average, with larger effects for exporters, financial firms, and foreign-owned corporations. A related natural experiment from the legal sphere is the bankruptcy of the city of Detroit, which is used as an instrument by Chari, Leary, and Phan (2018) to estimate the impact of bond yield shocks on the domestic economy of Puerto Rico. They find that higher (quasi-sovereign) default risk mostly affects employment in industries that are dependent on government demand.

\footnotetext{
${ }^{21}$ This relates to an earlier literature, which shows that sovereign bond spreads influence business cycles and domestic borrowing costs in emerging markets (Neumeyer and Perri 2005 and Uribe and Yue 2006).

22 Their mechanism is similar to Gennaioli, Martin, and Rossi (2014), Bocola (2016) and others, which are presented in greater detail in the next section.

${ }^{23}$ In earlier work, Arteta and Hale (2008) and Das, Papaioannou, and Trebesch (2010) find that sovereign debt crises are accompanied by a sizable drop in external borrowing by domestic firms. Esteves and Jalles (2016) come to the same conclusion using historical data on emerging markets prior to WWI.
} 
Other recent papers study the impact of sovereign rating changes and/or declines in sovereign bond prices on domestic corporations. Almeida et al. (forthcoming) exploit exogenous variation in the link between sovereign ratings and bank ratings, which arises from rating agencies' sovereign ceiling policies, and show that sovereign downgrades reduce firm investment and financial leverage. Ferrando, Popov, and Udell (2017) use a unique ECB database of survey information of more than 28,000 small and medium size enterprises (SMEs) in Europe to examine the effects of sovereign distress on the provision of credit. Based on a difference-indifferences methodology, they find that SMEs in countries experiencing sovereign distress face quantity and price rationing by banks. Brutti and Sauré (2015) and Bahaj (2020) use narrative approaches and high-frequency CDS data during the eurozone crisis to show how sovereign risk propagated across borders, thus raising borrowing costs for the domestic private sector.

What these theoretical and empirical contributions have in common is that sovereign risks and corporate risks are closely intertwined. Moreover, these studies focus on the transmission (or "pass through") of sovereign risk, measured by an increase in sovereign bond yield spreads or CDS premia. This, in turn, is closely linked to the channel of financial intermediation. In the next section, we will therefore delve into the role of banks and the financial system as a link between the public and the private sectors in episodes of sovereign distress.

\section{Sovereign bank linkages: the (Re?)-emergence of doom loops}

\subsection{Defaults and their effects on the financial sector}

The feedback between distressed banks and sovereigns featured prominently in the 2008 crisis and the European debt crisis, so much so, that commentators coined several terms to describe this interaction, including "doom loops," “diabolic loops," and "vicious cycles” (see e.g. Brunnermeier et al. 2016). Fears of the consequences of a Greek default in 2011-2012 were centered on sovereign-bank linkages, particularly as to whether the balance-sheet exposure to Greek bonds could trigger bank failures and worsen the economic downturn in Greece and Europe. In addition, the sovereign debt crises in Russia (1998) and Argentina (2001) suggested that government defaults directly affect bank balance sheets. Using country-level data, Borensztein and Panizza (2009) and Reinhart and Rogoff (2011a) were among the first to show that sovereign defaults help to predict banking crises. In the wake of the eurozone crisis, new strands of empirical and theoretical research built on these insights to better understand the mechanism behind the feedback loops as well as their economic costs.

Early theoretical contributions on the sovereign-bank nexus include Brutti (2011), Bolton and Jeanne (2011), and Gennaioli, Martin, and Rossi (2014) (GMR). What these three models have in common is that bank holdings of sovereign bonds generate contagious spillovers when default takes place. This creates costs akin to the default-induced output losses in Arellano (2008), and reduces the incentives for sovereigns to default, even in the absence of direct sanctions or reputational penalties. 
Brutti (2011) proposed a model that explains the coincidence in timing of defaults and banking crises in emerging market economies. A default can induce a liquidity crisis that reduces domestic production and investment, especially if the private sector has incomplete access to credit markets and is forced into holding government bonds directly (or indirectly through the banking sector). Bolton and Jeanne (2011) focus, instead, on financially integrated economies, such as in the eurozone. In their model, financial integration creates incentives for domestic banks to diversify their holdings of government bonds across countries. This generates risk diversification benefits ex ante, but results in costly spillovers in case a foreign-government defaults.

GMR (2014) show that lending by the banking sector can sharply decline in case of a sovereign default, especially if banks hold large amounts of sovereign bonds. In the model, unlike in earlier theoretical work, the central cost of default is the damage done to bank balance sheets. This results in a decline in bank lending and, consequently, a drop in investment and output. GMR apply their model to panel data between 1980 and 2005 and find that debt crises tended to be followed by a decline in private credit, especially in financially developed economies and when banks have significant government debt on their books. In follow-up research, GMR (2018) expand their empirical analysis using bank-level data across 191 countries and until 2012. They find that, on average, banks hold roughly 9\% of their assets as government bonds. In 20 instances of default, the lending drop is larger for banks heavily exposed to government bonds. Sosa-Padilla (2018) builds a closely related model in which a government's decision to default triggers a banking crisis through non-performing sovereign bonds, which in turn leads to a decline in the provision of credit to the private sector and output losses. His theoretical contribution is to endogenize the output cost of default. ${ }^{24}$

These models help to rationalize the concerns about a sovereign payment default in highly financialized economies like Spain or Italy. What this literature does not explain, however, are the potential sovereign-risk spillovers in countries that did not default. More recent work therefore considers whether beliefs about the potential default are sufficient to disrupt financial intermediation and stunt growth.

Bocola (2016) develops a model along these lines, where news that the government may default in the future can have adverse effects for bank lending and economic growth. When the price of the debt falls on secondary markets, the bank's net worth declines and bank funding costs rise. Banks respond by reducing lending to the private sector, which results in less capital expenditure and investment, which, in turn, can generate a recession. Bocola calls this the conventional liquidity channel, but he also models a second channel, which he terms the risk

\footnotetext{
${ }^{24}$ Perez (2015) proposes a second channel through which a sovereign default can create output costs via the banking system. In addition to the spillovers arising from banks' balance sheet exposure, his model contains a "liquidity channel." When governments default, less public debt is issued and bonds have low returns. As a result, banks shift from holding public debt to investing in lower productivity projects than they otherwise would, which ties up capital and will, all else being equal, lead to a lower aggregate output. See also Engler and Grosse Steffen (2016).
} 
channel. The belief that a default will occur in the future can alter a bank's willingness to lend to non-financial firms today. As banks become more cautious, they pass this along to their private sector customers by raising rates on loans. Banks also perceive private sector lending as riskier, resulting in sales of private-sector assets and lower bank net worth. The combination of precaution and perceived greater risk thus induces banks to reduce their exposure to the private sector, leading to a decline in lending and capital expenditure, and ultimately, to lower output. To understand the relative contributions of these channels, Bocola (2016) structurally estimates the model using data on the Italian debt crisis and shows that the risk channel accounted for $45 \%$ of the "pass through" of sovereign risk to firms' borrowing costs. He also finds that Italian output would have also been about 1\% higher annually without this sovereign distress effect. The paper thus provides an explanation as to why "debt crises without default" matter for the real economy.

A closely related empirical literature reinforces this point by showing how distress in European sovereign bond markets spilled over into the domestic banking sector, ultimately causing a credit crunch and higher firm borrowing costs. Acharya, Eisert, Eufinger, and Hirsch (2018), for example, find that poorly capitalized banks holding sovereign bonds reduced their syndicated lending by up to $50 \%$ at the height of the debt crisis. Similar results are reported by Altavilla, Pagano, and Simonelli (2017) and Popov and van Horen (2014) using data for euroarea banks, as well as by Bofondi, Carpinelli, and Sette (2018) and Bottero, Lenzu, and Mezzanotti (2020) using granular Italian data at the loan-, bank- and firm-level.

\subsection{Bank distress and spillovers to sovereigns}

Given their interconnected nature, doom loops could also arise from problems in the banking sector. If market participants expect distress in the banking sector and subsequent bank bailouts by the government, they will price that risk into sovereign spreads, triggering a decline in bond prices and, possibly, a rollover crisis. ${ }^{25}$ This, in turn, will affect bank balance sheets, further increasing the likelihood of a banking crises.

Acharya, Drechsler, and Schnabl (2014) develop a three-sector model to explore these feedback loops. The model features a financial sector with high leverage and exposure to systematic risk in the corporate sector. Financial firms face the possibility of bank runs, giving rise to government bailouts. Specifically, governments will respond by issuing new sovereign bonds and transfer the proceeds to banks so that their supply of credit does not fall. The new bond issuances, in turn, lead to debt dilution and higher sovereign credit risk, which then feeds back to the financial sector by reducing the value of its holdings of government bonds as well as the value of its government guarantees. Several testable predictions arise from this model, which are confirmed in their empirical analysis with sovereign and bank CDS premia. First, the announcement of a bailout initially reduces credit risk in the financial sector, but also increases

\footnotetext{
${ }^{25}$ Historically, costly rescue packages have taken many forms, including bank nationalizations, capital injections, guarantees for bank liabilities, toxic asset purchases, liquidity support from the central bank, deposit freezes, and bank holidays (Laeven and Valencia 2013).
} 
sovereign credit risk. Second, after the bailout, there is significantly more co-movement between sovereign and bank credit risk, even after controlling for banks' own equity returns. In sum, the paper shows that the bank bailouts where a "pyrrhic victory," with short-term beneficial effects that ultimately haunted sovereigns across Europe. ${ }^{26}$

Several other papers corroborate these findings. Mody and Sandri (2012), for example, trace the origins of the European debt crisis to the bailout of Bear Stearns in early 2008, which raised market expectations of costly government bank bailouts. The sovereign-bank feedback loop intensified after the nationalization of Anglo Irish Bank in January 2009 and, in particular, with the skyrocketing Greek bond yields in 2010. Relatedly, Acharya and Steffen (2015) show that banks in the periphery of Europe increased their holdings of domestic sovereign bonds, rather than decreasing them, as the eurozone crisis escalated, leading to a stronger feedback loop. Moreover, Ang and Longstaff (2013) use CDS spread data from US states and eurozone countries, finding that a significant portion of sovereign risk is linked to financial market conditions rather than driven by macroeconomic fundamentals. This is in line with the paper by Morelli, Ottonello, and Perez (2019), which shows that, in 2008, after the Lehman collapse, emerging market bonds held by more-distressed global banks were subjected to larger price declines.

\subsection{Are sovereign-bank doom loops becoming more severe? A historical perspective}

This subsection moves beyond the recent experience and explores historical precedents. Have sovereign-bank linkages intensified in recent years, perhaps because the economy has become more financialized as a whole (Jordà, Schularick and Taylor 2017)? Or has the issue of sovereign-bank contagion merely resurfaced in recent years? Shedding light on this question has implications for policy as well as for the external validity of the newer generation of sovereign debt models with financial intermediation. In addition, the theoretical discussion above raises an empirical question that history can help to answer: which typically comes first, banking crises or sovereign debt crises? Here we provide additional evidence on these questions.

There are good reasons to believe that banks and sovereigns have maintained close ties over the past centuries. Many of the initial banks owed their very existence to sovereigns. States, meanwhile, were often given privileged access to banking services. Indeed, before secondary markets emerged, private bankers often lent to sovereigns to finance wars and secure borders. There is also a long history of mutual assistance between banks and sovereigns. In wartime, banks aid sovereigns by absorbing new domestic debt issues. In turn, banks often receive emergency funding (e.g., liquidity support by a central bank) or direct capital infusions from states when in need (e.g. Reinhart and Rogoff, 2009). ${ }^{27}$ And in peacetime, banks can aid

\footnotetext{
${ }^{26}$ For a related model, see Farhi and Tirole (2018).

${ }^{27}$ An alternative view suggests that quickly backstopping and recapitalizing banks (as was done in the EMS crisis of the early 1990s) may limit losses to tax revenue and output and thus short-circuit the doom loop (Corsetti et.al. 2020).
} 
sovereigns by holding large amounts of bonds in their portfolios - to guarantee a market for the sovereign bonds and to allow nations to rollover their debt - a form of financial repression that was practiced after World War II (Reinhart and Sbrancia 2015).

Against this backdrop, we look for evidence of diabolic loops before the eurozone debt crisis. ${ }^{28}$ Since financial crises are rare events, and because banking crises cum sovereign crises occur even less frequently, we take a 200-year perspective. Our data and approach for identifying doom loops draws on Mitchener (2014) and Maerean and Mitchener (2016a), and uses existing databases of historical crises to pinpoint twin sovereign-bank crises that were coincident in timing - a necessary condition for the crises to be causally related. ${ }^{29}$ Maerean and Mitchener (2016a) define a "twin crisis" episode in year t when a banking crisis overlaps with a default during the period [ $t-3 ; t+3]$. By their definition, twin crises are thus a maximum of two years apart. $^{30}$ The data span 70 countries from 1800-2008 - with the sample's start date determined by the approximate date sovereign bonds became widely traded on secondary markets. ${ }^{31}$

With a view to Section 3 on "debt crises without default", we also want to analyze cases where sovereign bond "spread spikes" coincide with banking crisis events. That is, we consider debt crises even if there was no payment default, but merely debt distress as captured by rapidly rising bond yields. To identify "spread spikes," monthly sovereign bond yields for all countries that had banking crises during the sample period are employed and for which one can gather sovereign bond yield data. The Maerean and Mitchener pre-WWI sample contains 53 countries; thereafter, it consists of 42 countries. ${ }^{32}$ To compute spreads, we subtract a proxy of the riskfree rate, using the current yield on the UK consol for the period through 1913 and the U.S. long-term bond thereafter. To allow for comparability of spreads across countries, normalized spreads are constructed following Krishnamurthy and Muir (2017), i.e., the bond spread is divided by the sample average spread for a given country. Specifically, a spread crisis in year $\mathrm{t}$ exists if the annual change in the normalized spread is higher than the threshold $\bar{\Delta}$. Spread $_{i, t}$ Spread $_{i, t-1}>\bar{\Delta}$. The cutoff was selected after examining the distribution of spread changes and is equal to the 90th percentile. ${ }^{33}$ Using this approach, 177 spread crises can be found during

\footnotetext{
${ }^{28}$ This subsection draws extensively on Maerean and Mitchener (2016a).

${ }^{29}$ Crisis dates and frequencies are based on Reinhart and Rogoff (2009), Annual Reports of the Corporation of Foreign Bondholders, the Annual Reports of the Foreign Bondholders Protective Council, Mitchener and Weidenmier (2008), Mitchener and Weidenmier (2010), and Bordo et al. (2001).

${ }^{30}$ While sovereign debt crises can persist, most banking crises generally last for one to two years. Hence, given we are looking for correspondence, we chose the definition of twin crises to reflect the shorter duration of banking crises. Kaminsky and Reinhart (1999) use a similar range of 48 months two define balance-of-payment and banking crises as "twin crises."

${ }^{31}$ At the beginning of the 19th century, wealthy households held the bulk of sovereign bonds, but banks became increasingly important investors subsequently (Ferguson 2006). By 1883, the bonds of foreign governments accounted for 23\% of all securities quoted on the London Stock Exchange (Michie 1999, p.89, table 3), with large investment houses dominating the issuance of these bonds (Michie, 1999; Fishlow 1985).

32 The main data source for constructing pre-World War I bond spreads is the Investor's Monthly Manuel (IMM). Additional bond quotations were hand collected from the newspaper Berliner Börsen-Zeitung (BBZ) and consist of monthly prices of government securities quoted and traded on the Berlin stock exchange from 1870-1913. We use the Global Financial Database for data thereafter.

${ }^{33}$ The $90^{\text {th }}$ percentile is 0.18 for the first sample and 0.99 for the second sample period.
} 
1870-1913 and 57 spread crises during 1920-1935 (Maerean and Mitchener, 2016a). ${ }^{34}$ Note that the threshold is much less strict than in Section 3 on "debt crises without default," where we use the $99^{\text {th }}$ percentile, because the aim here is to capture as many potential events as possible within the two-year window of correspondence. ${ }^{35}$

Using the sample of spread crises, the data are then examined for overlapping banking crises, in a two-year window before or after. Since coincidence in timing is insufficient for identifying linkages between sovereigns and banks (i.e., yields may rise and banks may fail if economic shocks are simply large), we follow Friedman and Schwartz (1963), Jalil (2015), Richardson (2007), Wicker (1996) and other scholars who have used a "narrative approach" to identify financial crises historically. A narrative approach to explore whether spread crises were characterized by an interplay between the banking system and debt markets is employed. That is, we draw on articles in newspapers and periodicals, memoirs of bankers, businessmen, and policy makers, and reports of regulatory agencies to examine what was said by contemporaries and to rule out spread spikes that were coincident in timing but driven by unrelated events (and as discussed further below). The result is a taxonomy of historical sovereign-bank feedback events that can be compared to recent experience.

Evidence from realized defaults: The first two rows of Table 1 show the number of banking and sovereign debt crises identified for five different periods: pre-1870, the first era of globalization (1870-1913), the interwar period, the Bretton Woods era, and post-Bretton Woods. There were 59 banking crises and 36 sovereign debt crises in the first era of globalization, but only six were twin crises. Before 1870, the number of twin episodes was even smaller, just two, while in the interwar period, there were 10 twin crises. The total number of banking crises was quite small in the Bretton Woods period, leading to only one twin crisis episode. The largest number of twin crises (23 events) is in the modern period until 2008.

Table 1 further reports information on the sequencing of the crises for the twin episodes. The table distinguishes between simultaneous twin crises when: (i) the banking and debt distress occurred in the same year (row 4); (ii) the debt crisis occurred prior to the banking crisis (debtbank twin crises shown in row 5); and when the financial turmoil started prior to the public default (bank-debt crises shown in row 6). Across all sub-periods, banking crises have generally preceded debt crises. This remains true in the most recent period: of the 23 twin crises since Bretton Woods, 15 were characterized by the banking crisis occurring first. This historical analysis is consistent with Reinhart and Rogoff (2011a) and Laeven and Valencia (2013), who

\footnotetext{
${ }^{34}$ During default, countries experienced more spread crises as spreads were more volatile and suffered larger increases. For example, 78\% of the spread crisis episodes take place in defaulting countries during 1870-1913.

35 The country coverage and time periods in the two data sets also differ slightly. When using definitions and data from Section 3, we find a slightly different set of twin crises based on "spread spikes," but no additional cases of "doom loops" once the narrative evidence is also considered.
} 
show that, in general, banking crises are significant predictors of debt crises. Other studies show mixed results on this point. ${ }^{36}$

Table 1: Twin crises (bank \& debt) since 1800

\begin{tabular}{lccccc}
\hline Crisis type & $\begin{array}{c}\text { 19th century } \\
\text { (pre-1870) }\end{array}$ & $\begin{array}{c}\text { Pre-WWI } \\
(1870-1913)\end{array}$ & $\begin{array}{c}\text { Interwar } \\
(1919-1939)\end{array}$ & $\begin{array}{c}\text { Bretton Woods } \\
(1945-1973)\end{array}$ & $\begin{array}{c}\text { Post-BW } \\
(1974-2008)\end{array}$ \\
\hline $\begin{array}{l}\text { Total banking crises } \\
\text { Total sovereign debt crises }\end{array}$ & 37 & 59 & 51 & 3 & 117 \\
$\begin{array}{l}\text { Twin crises (bank \& debt) } \\
\text {.....of these: }\end{array}$ & 2 & 36 & 30 & 20 & 60 \\
simulatenous (same year) & 1 & 1 & 10 & 1 & 24 \\
debt crisis first & 0 & 1 & 2 & 0 & 7 \\
bank crisis first & 1 & 5 & 6 & 1 & 2 \\
\hline
\end{tabular}

Note: The period covered is 1800-2010, where WWI and WWII are excluded. Data are from Maerean and Mitchener (2016b, Table 4.1), with the following additions and corrections made by the authors: Peru (1875) was recoded as a twin crisis, where the banking crisis preceded the debt crisis, based on the date of its default listed in Borchard and Wynne (1951). Russia was not included in the original sample of countries; its 1988 crisis was added to the last column's figures.

Table 2 reports on the subset of twin crises with elements of a doom loop at work - meaning a banking crisis that spilled over to the sovereign or vice versa (i.e., we rule out episodes that are simply coincident in timing, but show no historical narrative evidence of a "connection.”). ${ }^{37}$

Based on our data and methodology, Peru, in 1875, is our first documented case of a doom loop. The income obtained from guano, a fertilizer and major export of the country, was central for servicing the external debt. In the early 1870s, exports of guano began to decline and fiscal deficits grew; further, the income from nitrate sales, another important and growing export of the country, was insufficient to fill the gap. Debt-servicing costs continued to grow faster than revenues. After the Banco Nacional del Peru failed in 1875, the government allowed noteissuing banks to increase emission if they in turn lent these paper notes to the government (primarily to meet debt obligations) in order to prevent a widespread banking panic. Further, the government intended to employ these banks as local consignees of nitrate production in a drive to nationalize the nitrate industry and use the nationalization proceeds for debt repayment. The nitrate producers balked at the government's nationalization program, which included land

\footnotetext{
${ }^{36}$ Borensztein and Panizza (2009) indicate the opposite pattern for approximately the same period, 1975-2000. Using data from the 1980-2005 period, Gennaioli, Martin, and Rossi (2014) find more episodes where the banking crisis started after the default. A comparable result is found in Balteanu and Erce (2018) for a similar period. The differences in findings may partly be explained by differences in methods, samples, and crisis dating. For example, Bordo and Meissner (2016) document different crisis chronologies among leading authors. ${ }^{37}$ From the perspective of timing, Germany might also seem like a candidate during the interwar period. It had a banking crisis in 1931 and defaulted on sovereign debt, beginning in 1932. However, its banking crisis appears unrelated (Doerr, Gissler, Peydro, and Voth 2019), and its sovereign debt presents a unique challenge in terms of analysis: it is reparations debt form WWI, the political dynamics of which may be entirely different from what is discussed in this survey. For detailed accounts of individual episodes and more information on the precise linkages between banks and sovereigns or vice versa, see Maerean and Mitchener (2016a).
} 
for government-bond swaps. Facing insufficient revenues, the government then suspended interest payments on its external debt in December $1875 .^{38}$

Table 2: "Doom Loops" prior to the eurozone crisis

\begin{tabular}{lll}
\hline \hline $\begin{array}{c}\text { Pre-WWI } \\
(1870-1913)\end{array}$ & $\begin{array}{c}\text { Interwar } \\
(1920-1939)\end{array}$ & $\begin{array}{l}\text { Post-Bretton Woods } \\
(1974-2008)\end{array}$ \\
\hline Peru (1875) & Austria (1931) & Argentina (1980) \\
France (1882) & Greece (1931) & Mexico (1981) \\
Portugal (1890) & Romania (1931) & Philipppines (1981) \\
Argentina (1890) & Poland (1931) & Chile (1982) \\
Norway (1899) & & Algeria (1990) \\
& & Venezuela (1993) \\
& & Indonesia (1997) \\
& & Ecuador (1998) \\
& & Russia (1998) \\
& & Turkey (2000) \\
& & Argentina (2001) \\
& & Druguay (2002) \\
\end{tabular}

Note: "Doom loops" are events where debt and banking crises overlap and in which historical narratives point toward close linkages between sovereign and banking sector distress. The two cases in italics are banking crises that overlapped with "spread crises," but in which there was no payment default. Data are from Maerean and Mitchener (2016b, Table 4.4), with the following additions and corrections made by the authors. As per Table 1, Peru was reclassified as a twin crisis, and classified as a doom loop based on the narrative evidence and sources cited below. We also classify Portugal as a doom loop based on Esteves (2011).

A second twin crisis with elements of a doom loop arose during the well-known Baring Crisis of 1890, which culminated in Argentina's default. In short, debt sustainability issues became apparent when the Argentine government started violating its legal obligations and began paying off gold liabilities with massively depreciated domestic currency. Shortly thereafter, the investment house of Baring failed in floating a 25 million gold peso loan in London on Argentina's behalf, and runs on the banks of issue, Banco Nacional and the Banco de la Provincia de Buenos Aires, followed. Panicky depositors feared a "sudden stop" in the supply of foreign capital, a situation that would put the government and banks (tacitly linked to the government) at risk. Fearing a meltdown of its banking system, the government authorized new paper notes to meet the heavy withdrawals of panicky depositors. But this intervention spooked investors: sovereign bond yields spiked and foreign capital fled Latin America (Marichal, 1989). Argentina's fiscal position worsened, and the country defaulted on its external debt in the same year.

\footnotetext{
${ }^{38}$ See Marichal (1989), Marichal (2014), and Vizcarra (2009).
} 
In the spring of the same year, 1890, a third pre-WWI "doom loop" had begun in Portugal, when the country had trouble placing new debt in Paris. A banking crisis followed in the fall of 1890, with the central bank providing critical support to the bank Montepio Geral. Despite guarantees by the central bank to other banks and railways, capital quickly flowed out of Portugal - even prior to the shock of the Baring Crisis, which only accelerated this trend. Continuing problems in the banking system and current account deficits led the country to abandon the gold standard and eventually to a partial default on its debt in the summer of 1892 .

Four more twin crises with “doom loop” elements develop in the interwar years. These are Austria, Greece, Poland, and Romania in 1931. In each of them, there was large-scale government support of the banking sector - whether it was through a direct bailout, through liability guarantees, or through bank nationalizations.

After World War II ended, we identify another 13 cases with “doom loop” features prior to the Great Recession of 2008, all of which occurred in developing and emerging-market economies. These cases can be grouped in two clusters and are well documented in the recent literature, in particular in Caprio and Klingebiel (2003) and Laeven and Valencia (2013, 2018), as well as in Das, Papaioannou and Trebesch (2012). The first cluster is during the debt crises of the 1980s and early 1990s (see Cline 1995). The second occurs in the late 1990s and early 2000s, when emerging markets were rattled by the Asian financial crisis, the Russian financial crisis, and the defaults in Argentina, Uruguay, and the Dominican Republic (see Sturzenegger and Zettelmeyer 2006 for detailed accounts).

Additional evidence from "spread crises": Thus far, the methodology for identifying doom loops only considers realized defaults. We now turn to examining the banking crises that coincide with "spread crises", i.e. rapid yield spread increases, using the data and methodology from Maerean and Mitchener (2016a) and described above. We find seven cases before WWI and 10 cases between 1920-1935. Since many factors besides banking crises drive risk premia, we again rely on the narrative approach to discern whether there is a connection between financial sector distress and sovereign debt distress. As it turns out, mapping historical spread spikes onto the timing of banking crises reveals a number of "false positives" - corresponding spread spikes that appear detached or unrelated to banking distress. For example, political factors (wars, coups d'tat, and border tensions) rather than banking troubles drove spread spikes in Brazil (1890), Russia (1875), Chile (1898), Uruguay (1898), and Italy (1935). In other instances, financial problems were mild, the dates of banking crises did not align, or the historical record simply did not show any connection between government debt policy and the banks. ${ }^{39}$

\footnotetext{
${ }^{39}$ For example, Australia (1931) is an episode where the financial troubles were very mild (Fisher and Kent 1999), Bordo et al (2001), Taylor (2015). For the case of South Africa (1877) and Germany (1925), there seem to be some dating errors by those who have previously classified them as banking crises. In India (1921), the narrative evidence suggests that there was no feedback loop between the banks and the state.
} 
For example, the Netherlands (1921), Argentina (1931), Belgium (1931), Finland (1931), Sweden (1931), and Switzerland (1931) appear to be more promising candidates for doom loops, but the narrative records reveal only weak evidence of a connection between banks and sovereigns. ${ }^{40}$ In several of the European cases, government rescue operations appear to have brought about stability to weak commercial banking systems and led to a faster recovery from the global depression of the 1930s (Eichengreen, 1992). ${ }^{41}$ Moreover, markets do not seem to have punished sovereigns for these bailouts: debt was rolled over and yields did not increase appreciably after governments intervened to support banking systems. As a result, and in contrast to the dynamics described in Acharya, Drechsler, and Schnabl (2014), no doom loop emerged as a result of bank assistance programs.

Despite the many false positives, we nevertheless identify two additional doom loops during "spread crises," namely France in 1882 and in Norway in 1899. In France, banks had lent heavily to private entities in the Austro-Hungarian empire in the late 1870s and early 1880s, but when that government refused to allow the Banque de Lyon to establish a new lending bank in Trieste, the lending bubble burst. In response, investors dumped bank stock and commenced a run on the Banque de Lyon. A panic at the Lyon Bourse soon ensued - leading to the collapse of both the bank and the exchange. Fear spread to the Paris Bourse, where another prominent investment bank, Société de l'Union Générale, had also set up multiple lending facilities in the Austro-Hungarian empire. An emergency loan of roughly 80 million francs, authorized by the government and initiated by the Banque de France, kept the Paris Bourse from collapsing as well. (The Banque de France in turn had to borrow from the Bank of England to provide liquidity to the commercial banking market). Government bond spreads reacted negatively to these events.

In Norway in the late 19th century, rapid population growth in the capital Christiania (modernday Oslo), fueled a lending boom by the commercial banking sector. Six new banks were established from 1897-1898, in addition to the eight already lending to fuel the real estate boom. In June 1899, Discontobanken, a newly established bank, saw a large borrower default on loans, leading to a run on the bank. The central bank of Norway provided direct support to the distressed lender, but the loan proved to be insufficient and the central bank assumed the bank's

\footnotetext{
${ }^{40}$ Hungary and Poland had banking crises in 1931 and defaulted on war loans in 1932, making them possibilities as well. However, like the candidate spread-crisis countries listed here, scholars interpret the twin crises as only loosely connected, with the banking crises emanating from the global shock of the failure of the Credit Anstalt in Austria in 1931 (Eichengreen, 1992). And, unlike the countries listed in Table 2, for this period, there is little evidence of a government bailout of banks.

${ }^{41}$ During the Netherlands (1921) episode, Nederlandsche Bank offered assistance to the financial sector which was considered successful and averted general runs on banks. In particular, the Netherlands Bank intervened in favor of the mid-sized Bank-Associatie and Marx \& Co. banks in 1922, and it also saved the extremely large Rotterdamsche Bankvereenig later in 1924. In Argentina (1931), the state bank, Banco de Nacion aided the private banks through rediscounts. In Belgium (1931), the National Bank offered support to several banks in 1932 and 1933 and, after some bank failures, the government stepped in and set up a company to mobilize banks' frozen loans. In Finland (1931), the Bank of Finland aided four banks with credits on special terms. In Sweden (1931), the Skandinaviska Kredit bank had to be supported by the Swedish National Debt Office. The support loan totaled 200 million SEK. In the last episode from our list, Switzerland (1931), the Swiss Volksbank and the Swiss Diskontbank were bailed out directly by the government.
} 
entire balance sheet. Norges Bank then found itself providing liquidity support to other struggling banks with significant exposures to the real estate market, but also began rediscounting bills more broadly to the entire banking sector. To backstop the central bank, the government turned over nine million kroner to the Norges Bank. Sovereign spreads rose dramatically during the crisis and the period of emergency lending, consistent with the theoretical literature discussed above.

When we sum the cases based on realized defaults with the spread-spike cases of Norway and France, we find nine instances of bank-sovereign “doom loops” prior to WWII and 13 episodes in emerging markets prior to 2008. It is possible that alternative methodologies may reveal additional cases; however, our reading of the long lens of history suggests that doom loops were relatively rare events until more recently.

Why might that be the case? It could be that, in the past, banks had more limited exposure to sovereign bonds on their balance sheets or that regulators today have unintentionally encouraged banks to "bulk up" on sovereigns. It could also be that market participants reacted differently to bailout announcements, or that expectations about their occurrence have changed. The higher frequency more recently could also reflect rising "financialization" (i.e., the increasing dependence on the financial sector for well-being and economic growth), making government bailouts in crises more likely. Additional empirical and theoretical research will no doubt help shed light on these potential explanations.

\section{Rollover crises and multiple equilibria}

As the eurozone crisis unfolded, it became increasingly apparent that solvency risk and liquidity risk were interacting. By the late 2000s, several eurozone economies faced challenges in refinancing existing stocks of public debt or placing new issuances, either because the offered rates were exceptionally high relative to previous borrowing or investors were unwilling to purchase more debt when governments turned to public markets. Shocks to "fundamentals," such as rapidly rising budget deficits in Ireland and Spain and large upward debt revisions in Greece in 2009, induced credit market participants to re-evaluate the ability of some governments to repay their obligations in the future. This heightened credit risk changed their willingness to refinance maturing debt and to demand greater compensation in the form of higher rates. However, the higher rates created a dangerous feedback effect, pushing eurozone economies closer to default. Commentators refer to these debt management problems as "rollover" or refinancing risk.

What drives rollover crises? And why did debt distress and rollover problems hit sovereigns in the eurozone while other advanced countries that also experienced weakening fundamentals and growing debt burdens (such as the U.S., Japan, and England) were spared? This section draws on a large volume of new theoretical research, in particular models emphasizing the self- 
fulfilling nature of debt crises, to address these questions and related issues. ${ }^{42}$ Since maturity is a central factor in these models and for default-risk modeling, in general, we also briefly discuss the growing theoretical literature that features long-maturity sovereign bonds.

Understanding whether crises are driven by investor expectations and beliefs has a long history, with important contributions by Obstfeld (1996), Calvo (1988) and Cole and Kehoe (1996, 2000). Models with self-fulfilling crises formalize some version of the following intuition: if markets come to believe that a crisis or default is more likely, they will price that into the interest rates of the sovereign, which in turn increases the likelihood that a country will default. ${ }^{43}$ Unlike earlier generations of sovereign debt models, Cole and Kehoe and Calvo show how the selffulfilling nature of debt crises can give rise to multiple equilibria. Recent theoretical advances build on their pioneering work by examining the elements of sentiment-driven crises that produce multiple equilibria, such as whether commitments to "good behavior" are rewarded by markets and whether the maturity of the debt matters.

Several new papers in this genre, use the eurozone debt crisis as motivation for modeling selffulfilling crises. ${ }^{44}$ For example, Conesa and Kehoe (2015) argue that rising debt-to-GDP ratios in the GIIPS countries were inconsistent with earlier-generation models, which showed that a rational response to the possibility of a self-fulfilling debt crisis was to pay down debt. To reconcile theory with recent events, Conesas and Kehoe (2015) develop a model showing that a government can rationally risk a self-fulfilling debt crisis and "gamble for redemption" when the economy is in a recession and recovery is uncertain. In such a situation, the government weighs the benefits of issuing more debt (more consumption smoothing, less painful adjustment) against the costs (that market participants will be more likely to engage in a speculative attack). Lenders and the government both hope for a recovery so that the government chooses not to cut spending and debt grows further. While rational, this "gamble for redemption" can sow the seeds of an eventual default and for the crisis to be self-fulfilling. The model helps to rationalize why crisis countries in the eurozone opted for debt accumulation rather than a more painful adjustment. It also contrasts from Reinhart and Rogoff's (2009) view (based on eight centuries of historical observations) that governments and lenders often delude themselves to lend and borrow more because they believe that "this time is different."

A related view is that the crisis countries were trapped in a "debt spiral," with increasing debt levels pushing up interest rates and vice versa. Lorenzoni and Werning (2019) follow this line of inquiry and construct a model with multiple-equilibria and limited commitment that

\footnotetext{
${ }^{42}$ Rollover risk in corporate debt markets received renewed theoretical attention in the wake of the crisis (e.g. He and Xiong 2012). Disruptions in the financial sector compounded debt overhang and the rollover risk of firms, and reduced corporate investment during the eurozone debt crisis (Kalemli-Özcan, Laeven, and Moreno, 2018).

43 Empirically, it is difficult to identify "bail out" expectations from other influences that simultaneously affect bond prices or yields. Bernal, Oosterlinck, Szafarz (2010) use quasi-natural experimental evidence from the 1918 Bolshevik repudiation of Russian bonds and segmented trading markets of these bonds to demonstrate that markets price bailout expectations.

${ }^{44}$ Aguiar et al. (2016) review the literature on quantitative models of default and study the role of investor's expectations in generating rollover crises. They find that a large fraction of the defaults are driven by beliefs.
} 
illustrates how debt dynamics were at the center of the observed rapid increase in interest rates during the eurozone crisis. They define "slow moving" debt crises as a situation characterized by rising interest rates that lead to greater debt accumulation which, in turn, induces a higher probability of default. They also explore policy options to reduce the vulnerability to these types of crises. When a fiscal rule is actively followed to combat rising deficits, the government's commitment to repay can be sufficient to prevent a self-fulfilling crisis. However, debt dynamics turn out to be quite sensitive to the stock of debt and other fundamentals: even when the equilibrium is unique, their model delivers a tipping point at which debt, interest rates, and default probabilities will rise over time and eventually lead to default. Initial debt levels are therefore crucial, pointing to the importance of keeping deficits in check. A further interesting feature of their model is that a large share of short-term debt exposes governments to greater refinancing risk, which can potentially amplify feedback effects. ${ }^{45}$

Bocola and Dovis (2019) also focus on multiplicity and the role that debt maturity plays in selffulfilling crises. Their model seeks to understand whether the eurozone bond spread crisis was driven by "fundamental risks," defined as growing default risk due to low output and high debt, or by "non-fundamental risks," meaning lenders believe that debt will not be rolled over, resulting in a self-fulfilling crisis. In their model, government decisions about debt maturity are critical for understanding the nature of default risk. If rollover risk is important, then a government has an incentive to lengthen the maturity of its bonds to reduce the payments that are coming due. The alternative is to choose shorter maturities as a way to raise more resources (the same trade-off features in other models with long maturity bonds discussed below). Thus, in this framework, the observed maturity choice of governments reveals the nature of the crisis. Going short suggests that fundamental risks are at work, while going long point towards rollover risks. Based on this idea, they calibrate their model using Italian data and find that rollover risk accounts for no more than 20 percent of Italy's spread spike during the eurozone crisis. Most of the increase in interest rates appears to be explained, instead, by economic fundamentals.

The models discussed thus far help to rationalize how the crisis could escalate so quickly in peripheral Europe, yet they do not help to explain why it hit the eurozone, specifically. Several authors make contributions along those lines by focusing on the institutional constraints of monetary unions and political unions. De Grauwe (2012) argues that entering into a monetary union (MU) and issuing debt is analogous to emerging-market economies issuing debt in foreign currency: in both situations, it can lead to self-fulfilling debt crises. A country joining a MU loses control over the currency in which it issues debt, so that it becomes more susceptible to investors losing confidence in the country's bonds. Once in the "bad equilibrium" and facing a recession, markets re-assess the prospects of default, potentially triggering both a liquidity and solvency crisis. Relatedly, Aguiar et al. (2015) explore the interaction between fiscal and

\footnotetext{
${ }^{45}$ Gros's (2012) multiple equilibria model also has a "slow moving” component, where the government's decision on the amount to pay to creditors emerges over time and is dependent on the cost creditors can impose on the debtor as well as the cost of additional revenue.
} 
monetary institutions in a monetary union and its implications for rollover crises. In their model, countries joining a MU are incentivized to issue too much debt because monetary and fiscal authorities can only imperfectly commit to inflation targets and repayment of debt, respectively. This can give rise to coordination problems and rollover crises. Monetary unions naturally respond to this externality by imposing institutional constraints on borrowing, i.e. debt limits.

Bianchi and Mondragon (2018) similarly focus on whether EMU membership increases the likelihood that an economy is subjected to a rollover crisis. The paper adds downward nominal wage rigidities and foreign currency debt to a Cole and Kehoe type model, and shows that, in countries lacking monetary independence, a sudden change in investors' desire to rollover debt can induce a recession. Due to the rollover crisis, the member state would need to tighten its fiscal belt to meet its debt payments, making default a more attractive option - an outcome that would rationalize investors' initial belief that the country would default. The authors calibrate their model and find that, with fixed exchanges rates, rollover crises are seven times more likely to happen. Using Spanish data from the 2000s, they find that Spain would have been insulated from a rollover crisis, if it had exited the eurozone and had the ability to pursue monetary policy for macroeconomic stabilization. In line with these findings, Corsetti et. al. (2014) demonstrate how currency unions can spread distress among its constituent members. Using a new Keynesian model, they demonstrate that the combination of a debt distressed member and procyclical fiscal policy throughout the union raises the likelihood that the entire MU experiences a belief-driven deflationary downturn.

If debt crises are self-fulfilling, what are the implications for policy? Corsetti and Dedola (2016) suggest that unconventional monetary policy can be an effective way to reduce the likelihood of a self-fulfilling crisis. In their model, central banks can purchase a sufficient quantity of sovereign debt (it can "turn on the printing press") such that it is not optimal for a government to default on its debt. ${ }^{46}$ A similar channel is explored in Roch and Uhlig (2016), who consider the role of a "bailout agency" in reducing the likelihood of a debt crisis, more specifically those crises driven by sunspots as in Cole and Kehoe (2000). They model an institution similar to the ECB's outright monetary transactions (OMT) program, which was announced in 2012 with potentially unlimited purchases of distressed members' government bonds. A key result from the model is that their bailout agency would need to be willing to potentially purchase (nearly) the entire amount of newly-issued debt to prevent a default.

A growing body of theoretical research thus points to rollover problems as an important element in the eurozone debt crisis. That said, it is unclear whether the dynamics in Europe represent a historical anomaly - possibly due to the institutional straight-jacket of the single currency area -- or whether self-fulfilling crises have become more prevalent, in general. An informed assessment is complicated by the fact that, compared to the thriving work in theory, very little

\footnotetext{
${ }^{46}$ Between May 2010 and November 2011, the ECB purchased roughly 200 billion euros of sovereign bonds (4 percent of eurozone GDP), although it offset the potential for monetizing with sterilization policies (Lane, 2012). See Bacchetta, Perazzi, and Can Wincoop (2018) for another study exploring whether monetary policy can be used to ward off a self-fulfilling debt crisis.
} 
empirical research on rollover crises or sentiment-driven defaults has emerged. ${ }^{47} \mathrm{~A}$ first, yet unsolved challenge is to measure rollover risk and tabulate rollover crises over long sample periods, and to distinguish these from solvency crises or "fundamental-driven" defaults. ${ }^{48}$ Further, there is scant evidence on the costs of rollover crises and little analysis of which policies are most effective at reducing rollover risks, such as debt maturity management or liquidity buffers (IMF, 2011). There is thus considerable scope for future research using both modern and historical data.

This discussion alludes to the importance of debt maturity in driving default risk, yield spreads, and rollover crises. The theoretical literature of the past decade has recognized this and moved away from models with one-period bonds towards models that incorporated longer maturities instead. Accounting for long-term debt is an important step forward for matching models to data, in particular with respect to bond spreads and default frequency. For example, models incorporating long-term debt allow researchers to examine the risk of debt dilution, to show how maturity choice is endogenous and procyclical, and to explain why bond maturity shortens in crisis periods and why the yield curve inverts as countries approach default. We refer the interested reader to the survey by Aguiar and Amador (2014), which describes the recent advances in this strand of the literature.

Several open issues remain in this literature, including how to measure rollover crises empirically and how to match theory and data convincingly. Taking a longer-run empirical perspective, the relative frequency of rollover crises in earlier eras has yet to be thoroughly investigated. The same is true for the impact of maturity choice on rollover risk. Indeed, there are several related questions concerning government bond maturity choice that deserve more research. For instance, what factors account for the decline in the average maturity of bonds from 40 or 50 years in the $19^{\text {th }}$ and early $20^{\text {th }}$ century to less than 10 years today (see Meyer, Reinhart and Trebesch 2019 or Ellison and Scott 2020), and what explains the observed cycles in maturity choice beyond default risk and crises? For example, why has the average maturity in OECD countries recently increased again, from around five years in the late 1990s to more than 8 years in $2019 ?^{49}$

\section{A global phenomenon: the rise of domestic debt and default}

The previous sections focused mostly on advanced economies, in particular on lessons from the eurozone crisis. In the next three sections, we take a more global perspective by considering

\footnotetext{
${ }^{47}$ Among the few exceptions is De Grauwe and Ji (2013). They identify structural breaks and periods when market sentiment diverged from fundamentals during the eurozone crisis, as captured by variables such as the current account, the real effective exchange rate, debt-to-GDP, and debt-to-government revenue. Based on their results, they argue that much of the rise in sovereign debt spreads in 2010-11 was unrelated to economic fundamentals, consistent with self-fulfilling crisis dynamics.

${ }^{48}$ As a first step along these lines, Cohen and Villemot (2015) examine 97 countries from 1970-2004 and find that roughly a tenth of all debt crises can be described as a self-fulfilling crisis, defined as an endogenous weakening of a country's fundamentals.

${ }^{49}$ See OECD Sovereign Borrowing Outlook 2020.
} 
sovereign debt market developments that also or mainly apply to developing and emerging economies. One such trend is the growing dominance of debt issued in domestic currency and under local law. ${ }^{50}$ In the 1990s, Eichengreen, Hausmann, and Panizza (2005) found only few developing countries that borrowed long-term debt in their own currency, a phenomenon they termed "original sin." According to this concept, many countries had no choice but to issue long-term debt in foreign currency, exposing them to global shocks and exchange-rate risk. Since then, however, many countries seem to have overcome this hurdle, with domestic debt issuance hitting new records, especially in the 2010s. ${ }^{51}$

Figure 9: The domestic bond boom - data on 100+ EME and developing country sovereigns

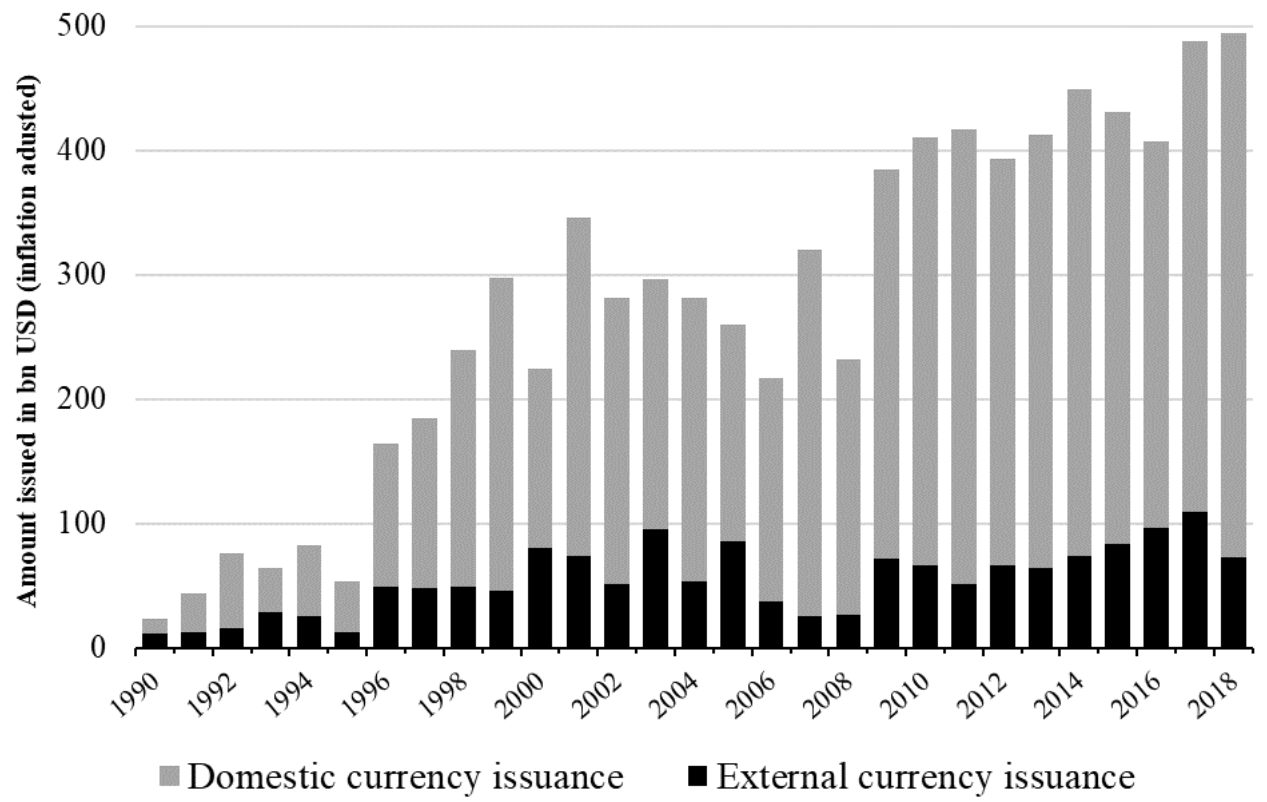

Note: Figure and data from Stoppok and Trebesch (2022). The graph sums the amounts of sovereign bond issued in external currency and domestic currency for more than 100 developing and emerging market countries 1990-2018.

Figure 9 shows a strong increase in the share of domestic currency debt in total public debt issuance for emerging market sovereigns over the past 40 years. Foreign currency borrowing has not disappeared, but now most emerging markets issue a significant amount of their government debt in local currency. ${ }^{52}$ From a longer-run perspective, the global boom in

\footnotetext{
${ }^{50}$ See Erce, Mallucci and Picarelli (2021) for an overview on how domestic debt and default has been measured and defined in the literature. The three main options are to classify domestic debt by: (i) the jurisdiction applicable to the debt instrument (local or foreign law); (ii) by currency of issuance; or (iii) the residency of the holder. In practice, the latter is particularly hard to measure.

${ }^{51}$ Eichengreen and Hausmann (1999) defined "original sin" as a situation in which "the domestic currency is not used to borrow abroad or to borrow long-term even domestically." Subsequent research has defined it as the inability to borrow in domestic currency abroad. Here, we interpret the concept simply as limits to domestic borrowing.

${ }^{52} \mathrm{Du}$ and Schreger (2016) collect data for 14 developing countries and show that the average share of external government debt issued in local currency is now roughly 60\%. Ottonello and Perez (2019) sample of 18 countries suggests a somewhat lower figure, but still has the share of local currency debt growing from 10 to $39 \%$ over the past decade or so.
} 
domestic bond issuance is reminiscent of history, as many emerging markets issued debt domestically in the $19^{\text {th }}$ century and during the interwar years, with similar maturities as external debt (Reinhart and Rogoff 2009, Mitchener and Weidenmier 2015). Advanced economies have long issued most of their debt in domestic currency, with only little external bond issuance (see Meyer, Reinhart, and Trebesch 2019). This is also true for countries in the eurozone periphery before the crisis, as Greece, Ireland, Italy or Spain had issued debt under domestic law and in the common, domestic currency, the euro.

In response to these changing trends, researchers have started to examine contractual features of sovereign debt issuance more closely, including the currency denomination (as mentioned, local or hard currency), but also where the bond was issued (marketplace and governing law), and who holds the debt (investor residence and senior claimants).

One branch in this new literature explores the phenomenon of domestic default and restructurings in advanced and emerging economies, which had received little attention earlier. ${ }^{53}$ Reinhart and Rogoff (2011b) present the "forgotten history of domestic debt" showing that, over a long sweep of history, domestic borrowing and defaults are more common than previously known. They document what they call de jure defaults, defined as missed payments or restructurings of domestic debt, as well as de facto ones, e.g. arising from surprise inflation that erodes the value of outstanding domestic debt. ${ }^{54}$ They also show that many domestic defaults occur in tandem with external ones, but far from all.

The boom in domestic debt issuance and the increasing number of domestic defaults also raises thorny issues about the relative seniority of domestic versus external creditors during crises, as examined in theory papers such as Guembel and Sussman (2009), Broner, Martin, and Ventura (2010), Broner and Ventura (2016), or D’Erasmo and Mendoza (2018). Broner et al. (2014), for example, suggest that domestic creditors are senior to external ones (meaning domestic debt is less likely to be defaulted on), possibly because governments care more about the welfare of domestic investors. Over the past 30 years, evidence on the claim that domestic creditors are senior in debt crises situations is mixed, also because researchers have used different definitions of what constitutes domestic debt, namely by currency, holder, and jurisdiction. Sturzenegger and Zettelmeyer (2006), Jeanneret and Souissi (2016), Erce and Mallucci (2018) and Erce, Mallucci and Picarelli (2021) show that, in some emerging-market crises, domestic creditors were favored, while in other crises no significant differences were detected. During the euro crisis, Brutti and Saure (2016) document large-scale “debt repatriation,” meaning that foreign investors sold their sovereign bonds to residents, which they interpret as evidence that domestic holders were perceived as senior. Historically, the picture is clearer: Meyer (2021) documents that domestic currency bonds faced a significantly higher probability of default and higher haircuts than foreign currency bonds. More work is needed to understand the determinants and

\footnotetext{
${ }^{53}$ As discussed above, related research explores domestic default in currency unions (Aguiar et al. 2015), and their associated redenomination risks (e.g. De Santis 2019, Kriwoluzky, Müller, and Wolf 2019).

${ }^{54}$ Whether and how public debt can be inflated away is further studied by Aizenman and Marion (2011), Hilscher, Raviy, and Reis (2014) and Krause and Moyen (2016).
} 
consequences of domestic default and the role that seniority and the political economy plays in this context.

Another strand of research explores the costs and benefits of domestic versus external sovereign debt issuance. One potential benefit is that domestic debt allows more hedging against shocks because there is no currency-mismatch between government revenue and debt repayment and because monetary and exchange-rate policy can be adjusted to reduce the debt's real value, i.e., through inflation. In line with this, recent empirical evidence on historical episodes (Bordo, Meissner, and Stuckler 2010) as well as on more recent periods (Dell'Erba, Hausmann, and Panizza 2013, Catão and Milesi-Ferretti 2014) shows that a higher ratio of external indebtedness is associated with a higher likelihood of debt distress and defaults. Moreover, Du and Schreger (2016) show that local currency sovereign bonds are less risky than commonly thought. Using a dataset of domestic sovereign bonds in 14 emerging markets, they develop a methodology to measure local currency bond risks by benchmarking against a synthetic domestic risk-free rate, yielding two important insights. First, domestic-currency bonds are more insulated against global shocks than foreign-currency bonds, meaning that they exhibit lower cross-country correlations and are less driven by global risk factors and global crises. Second, average risk premia on domestic bonds for EMEs are sizeable, but in comparison, they are lower (not higher) than on external bonds. Both findings help to explain the growing appeal of borrowing in local currency.

The resolution of debt distress and defaults is another reason why issuing domestic debt can be advantageous for sovereigns. Legal scholars have long emphasized that domestic defaults are easier to resolve, mainly because bonds issued under local law can be amended by an act of parliament, as happened in Greece 2012 (Buchheit and Gulati 2018). ${ }^{55}$ There is no such "local law advantage" for debt issued in foreign jurisdictions, where creditors are protected by the rule of law abroad and have more options for legal enforcement via courts (see Section 9 as well as Chamon, Schumacher, and Trebesch et al. 2018 and Schumacher, Trebesch, and Enderlein 2021). Beyond the legal realm, governments can also exert "moral suasion" on their domestically regulated banks and institutions, meaning they can pressure them into purchasing domestic sovereign debt or into accepting a debt exchange offer. Recent research documents that such "moral suasion" played an important role in the eurozone crisis and in earlier crises involving domestic debt (Acharya and Rajan 2013, De Marco and Macchiavelli 2016, Ongena, Popov, and Van Horen 2019). This is consistent with Reinhart and Sbrancia (2015) and Reinhart and Rogoff (2015), which suggest that debt conversions and other tools of "financial repression" were used to resolve debt overhangs in advanced countries in the $19^{\text {th }}$ and $20^{\text {th }}$ century (see also Chari, Dovis, and Kehoe 2020). Compared to domestic banks, it is much more difficult for sovereigns to exert pressure on external creditors who have less skin in the game and whose incentives often are unaligned (Reinhart and Trebesch 2015a). This may be one of

\footnotetext{
${ }^{55}$ Prior to the debt exchange of 2012, the Greek parliament passed a law that retroactively inserted collective action clauses (CACs) into outstanding domestic law bonds, so that a majority of bondholders could vote on the exchange of all outstanding Greek bonds, at a haircut above 50\% (Zettelmeyer, Trebesch, and Gulati 2013).
} 
the reasons why external debt crises tend to take much longer to resolve than domestic ones, dragging on for years or even decades (Reinhart and Rogoff 2009). Further, in the case of the eurozone, the Greek debt restructuring was complicated by the fact that most Greek government bonds were held by foreign banks and investors, who strongly opposed a deep haircut to bring Greece back to debt sustainability. The restructuring with a deep haircut took place only after investors were promised additional, taxpayer-financed cash transfers (Zettelmeyer, Trebesch, and Gulati 2013). In sum, "home bias” in sovereign debt issuance can help when your home is in distress since domestic creditors may be more prone to roll over debt and to share the burden of crisis resolution.

If domestic debt has obvious benefits, why, then, do countries continue to issue debt in foreign currency and in foreign markets? A series of recent theory papers explores this question, focusing on two potential explanations: inflation risk and policy credibility. The research emphasizes that governments are unable to commit to monetary policy, exchange-rate policy, and debt policy, making it hard for them to issue domestic bonds. Such commitments prove particularly problematic for emerging market borrowers and commodity exporters that face frequent, negative terms-of-trade shocks (Drechsel and Tenreyro 2018). Indeed, maintaining credible commitments has proven difficult for EMEs since at least the $19^{\text {th }}$ century. Even when developing countries committed to hard pegs during the classical gold standard era, frequent commodity-price shocks led investors to price expected depreciation into domestically-issued bonds of EMEs (Mitchener and Pina 2020).

An example of this line of research is Du, Pflueger, and Schreger (forthcoming), which uses a New-Keynesian model to examine how the credibility of monetary policy and risk-averse borrowers affects the currency composition of sovereign debt. They provide empirical evidence that countries with more credible monetary policies are able to issue more domestic debt. Their model offers an explanation: governments lacking credible commitments will pursue “excessively countercyclical” inflation policies ex post, resulting in higher risk premia on local currency debt and, thus, less domestic issuance. Ottonello and Perez (2019) also study the currency composition of sovereign debt. In their model, domestic currency issuance provides a means for governments to hedge against income shocks. Since exchange rates depreciate during recessions, a greater share of debt issued in domestic currency will reduce the real debt burden and attenuate some of the real shock. However, as in other models of this type, the perverse incentives to inflate or depreciate away the debt are constrained by investors who bake it into bond prices and yields ex ante. In equilibrium, the government must take this into account in choosing the amount of home-currency debt it issues. Relatedly, Engel and Park (2018) show in a model of a small, open economy that governments with more discipline in their monetary policy are able to borrow more in local currency and thus can hedge shocks better. These theoretical results are consistent with the evidence in Burger and Warnock (2006), which finds that local currency bond markets are more developed in countries where institutions are stronger, and inflation is stable. This may also relate to events in Europe after 1999. Aguiar et al. (2015) show that countries can gain inflation credibility by joining a currency union: this 
may have fostered the domestic borrowing boom in the eurozone after 1999. Further, recent research suggests that the issuance of domestic-currency debt has increased in the last 20 years, especially for advanced economies with good fundamentals (including stable inflation and low debt-GDP ratios). Interestingly, this trend appears to have been accelerated by the 2008 crisis (Hale, Jones, and Spiegel 2020).

The findings in this literature suggest that, with financial development, emerging market countries will issue a significant amount of debt in their home currency and under local law going forward. Consequently, it would not be surprising if we witness more domestic sovereign defaults in the $21^{\text {st }}$ century.

\section{International bailouts and the return of official sovereign lending}

A second major trend of global relevance is the growing role of official rather than private creditors in sovereign debt markets. As we have shown, recent advances in the literature have focused largely on lending via sovereign bonds, typically contracted with commercial banks or investment banks. This section considers another type of lending that has, once again, become an important source of financing for governments worldwide, namely official international lending. Official lending includes sovereign-to-sovereign loans (those between governments), central bank-to-central bank lending as well as lending by international and regional financial institutions. Compared to private lending, considerably less is known about official loans and defaults, both empirically and theoretically. Here, we summarize the small emerging literature on the topic.

Official international lending has resurged for at least three reasons. First, international bailout lending to advanced and emerging market governments reached new heights during the tumultuous years between 2008 and 2012. Second, new sovereign lenders have emerged, partly filling the gap left by the traditional $20^{\text {th }}$-century bilateral lenders, such as the US government. Most notably, the government of China has become a major global creditor, extending largescale loans to developing countries around the world, often with strings attached (such as preferential access to raw materials). Third, due to reserve accumulation by EMEs and domestic bond purchase programs in advanced countries, central banks have become major holders of sovereign debt (see Section 2). Here we show that lending flows between central banks of different countries have also returned on a large scale, today in the form of short-term central bank "swap lines."

\subsection{Bailouts and international rescue lending: patterns, determinants, and consequences}

Over the past decades, the likelihood and size of sovereign bailouts has grown substantially as shown by Roubini and Setser (2004) and Barkbu, Eichengreen and Mody (2012). This development has further accelerated since the crash of 2008 and the subsequent European crisis. The rescue packages arranged by the IMF and regional institutions, such as the European Stability Mechanism (ESM), were larger than anything we had seen since World War II, and 
easily surpassed the scale of rescue lending during the 1980s debt crisis, the Asian crisis of 1997/98, the Mexican peso crisis of 1994, and the Russian crisis of 1998. At the same time, the reliance on debt restructurings with private creditors ("bail-ins") has declined. Ireland, Portugal, and Spain received record amounts of official support in 2010-2012; however, with the exception of Greece, private bondholders were paid in full and on time and did not face a debt restructuring or "haircut." 56

Figure 10 documents the trend toward larger international bailouts. IMF program size has increased notably over time, in particular in advanced countries and large emerging markets. Of the 20 largest IMF lending programs since WWII, almost all (17) occurred since 1998 (Reinhart and Trebesch 2016b). Adding to this trend, the IMF recently arranged the largest program in history, Argentina's 2018 USD 57 billion program. Moreover, since the start of the global pandemic, more than 100 member countries signed up for IMF emergency financing.

Figure 10: Sovereign bailouts: IMF programs, 1960-2013

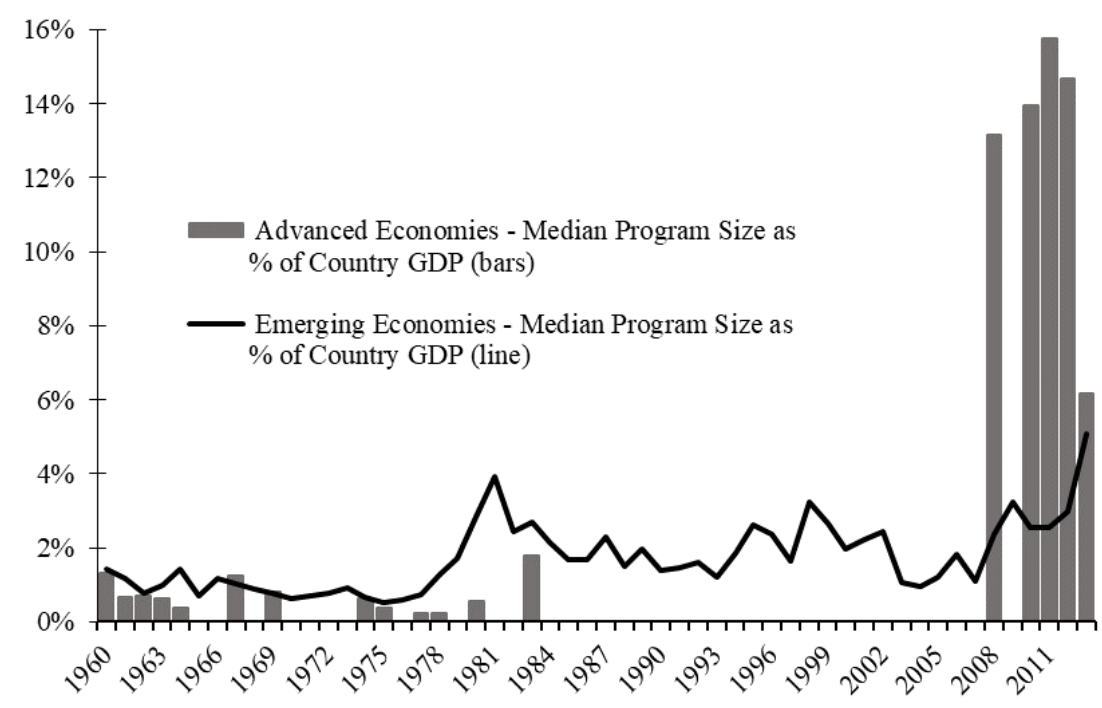

Source: Reinhart and Trebesch (2015b, Figure 6 of WP Version) based on IMF MONA WDI

Cross-border lending by sovereigns and other official creditors, such as central banks, is also an important feature of historical debt markets. Bordo and Schwartz (1999) show that "country rescues," as they call them, occurred regularly since the 19th century, albeit they were smaller and more ad hoc than today. In line with this, Horn, Reinhart, and Trebesch (2020) find dozens of events of international rescue-lending in response to financial crises, e.g. during the Baring crisis of the early 1890s and the Panic of 1907. More generally, building on a newly assembled database, they find that total sovereign-to-sovereign lending is large, often exceeding total private lending to sovereigns, particularly during disasters and wars, such as WWI and WWII. Figure 11 shows that the record bailouts between 2008 and 2012 pale in comparison to the huge cross-border official transfers during and after the world wars. The 1950s and 1960s also stand

\footnotetext{
${ }^{56}$ There was also a minor debt restructuring in Cyprus involving a subset of the debt and a low haircut.
} 
out as an era of large-scale official flows, while private cross-border investments were impeded by widespread capital controls and tight regulation of financial markets.

Why are governments willing to extend international rescue loans to other governments and what explains their size and direction? Relatedly, why do some of the largest bailouts occur between neighboring countries, e.g. by the US towards Mexico or within a monetary union? Tirole (2015) addresses these questions with a model of "country solidarity," in which the main driver of rescue lending is the fear of adverse, cross-border spillovers. Rescue lending is largely a function of economic self-interest, since assisting a crisis country reduces the potential for collateral damage to the rescuer's economy. The existence of negative spillovers to nearby economies has been well documented in historical debt crises (e.g. Mitchener and Weidenmier, 2008). By that same rationale, rescue lending will increase with the scale of economic and financial integration between two countries. This helps to explain the large and spontaneous “ex-post” bailouts arranged between the highly integrated eurozone economies in 2010-12. The same basic mechanisms also influence the optimal "ex-ante” insurance contract. Tirole (2015) shows that, in case of large asymmetries between countries, healthy economies have no incentives to enter a join-and-several liability contract ex-ante, e.g. via eurobonds. Instead, in a setting like the eurozone, the optimal contract relies on market financing and a borrowing cap.

Figure 11: Official international lending, 1790-2015 (bilateral and multilateral)

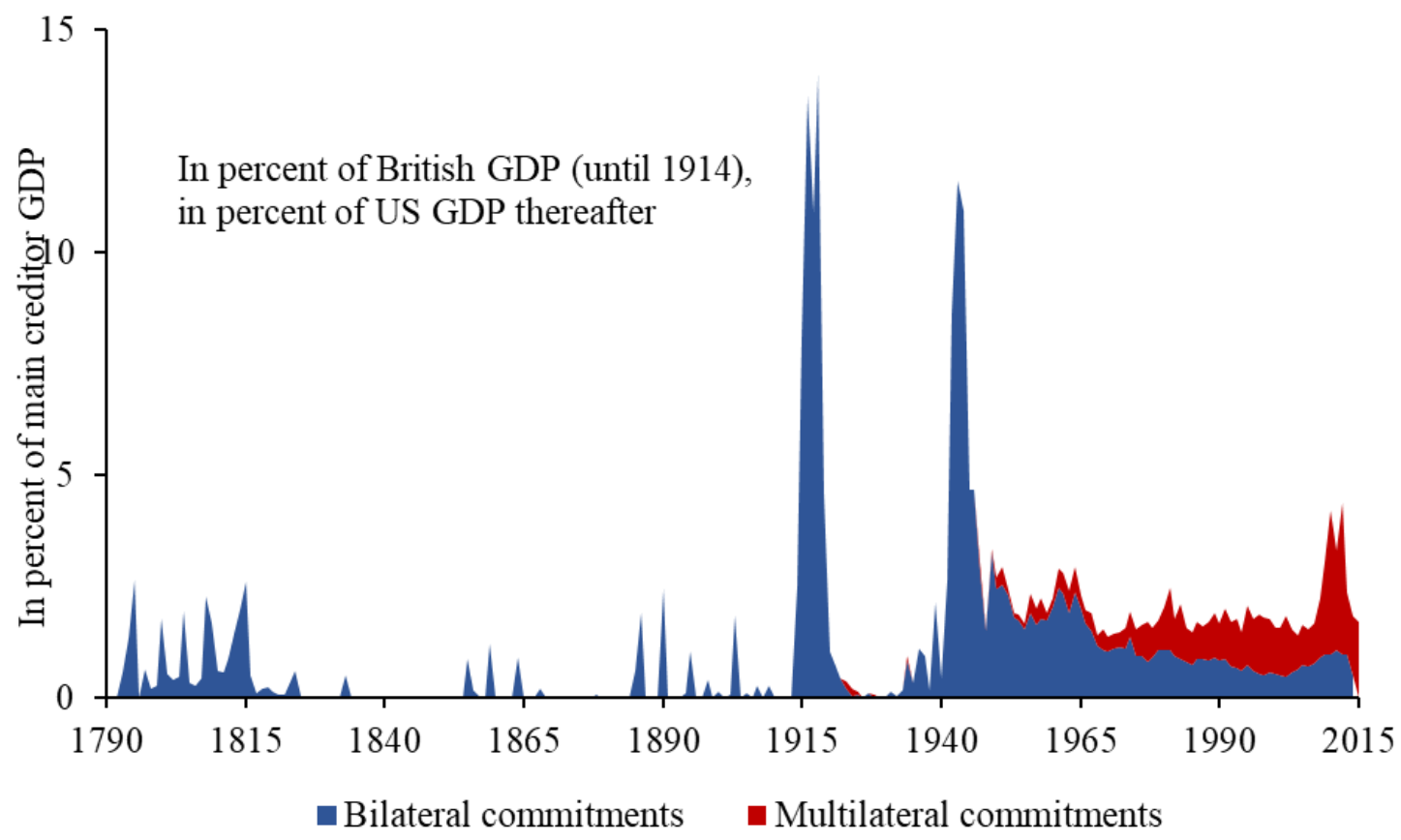

Note: Figure 3 from Horn, Reinhart, and Trebesch (2020). Gross aggregate official lending commitments by multilateral and bilateral creditors in percent of the main creditor's GDP. The data includes commitments through grants and loans, but excludes official portfolio investments and central bank swap credit.

Gourinchas, Martin, and Messer (2020) and Azzimotti and Quadrini (2018) also find that international bailouts between integrated economies are "ex-post" efficient and welfare improving since they reduce the crisis costs of both creditor and recipient country. The driving 
force is the same: governments are willing to extend rescue loans to other governments in order to reduce the economic externality caused by a default or "euro exit". Gourinchas, Martin, and Messer (2020) further show that the entire surplus of such bailouts goes to the fiscally strong "northern" countries. This is because the creditor government has no incentive to give more than the bare minimum transfer that keeps the debtor country from defaulting. As a result, in equilibrium, the bailed-out country is indifferent between a default and a bailout and is not made better off by rescue lending. This result is consistent with Jeanne and Zettelmeyer (2001), who find that the cost of international bailouts is largely borne by domestic taxpayers rather than by the taxpayers from abroad.

Using newly collected data, Horn, Reinhart, and Trebesch (2020) and Schneider and Tobin (2020) study the determinants of bilateral rescue lending empirically. Both papers confirm theoretical priors: official lending during crises is significantly larger between countries that have close trade and financial linkages, measured by trade and banking exposure. This finding holds both in historical and modern data and suggests that "country solidarity" is largely a function of economic self-interest of the creditor government.

Having discussed why international bailouts occur, what are their consequences? Besides reducing costly, cross-border spillovers, one potential effect of international bailouts is to lower the likelihood of default and debt restructurings on private debts (Dellas and Niepelt 2016). This may be one reason for the increasing prevalence of "debt crises without default" (Section 3), such as in Portugal in 2011/12, which avoided default largely due to the large-scale and concessional ESM and IMF loans.

In line with this, Schlegl, Trebesch, and Wright (2019) find that private creditors have become increasingly senior compared to bilateral government-to-government creditors. Building on a newly constructed database of haircuts and arrears towards official and private creditors, they show that sovereigns favor foreign banks and bondholders when it comes to repayments. The default probability is significantly higher for bilateral creditors, i.e. on debts owed to other sovereigns. In addition, the size of haircuts suffered by bilateral official creditors is significantly higher than that on private (bank and bond) debt.

International bailouts thus lower the expected losses of private creditors, which reduces sovereign bond yields, as emphasized in Dell'Ariccia, Schnabel, and Zettelmeyer (2006), Roch and Uhlig (2018), and Gourinchas, Martin, and Messer (2020). ${ }^{57}$ The reduced borrowing costs may, however, have the unintended effect of inducing overborrowing, especially by countries with weak fundamentals. This, in turn, raises the probability of default in equilibrium, with destabilizing effects on political and economic unions (Fink and Scholl 2016, Roch and Uhlig 2018). One possibility for addressing this type of debtor moral hazard is to agree to fiscal rules (Dovis and Kirpalani 2020), or alternatively, to demand that the debtor country implement

\footnotetext{
${ }^{57}$ An alternative view is discussed in Steinkamp and Westermann (2014).
} 
reforms (Müller, Storesletten, and Zilibotti 2019) and adhere to policy conditionality (Jeanne, Ostry, and Zettelmeyer 2008). ${ }^{58}$

It may also matter how bailouts are implemented as suggested in the case of bank rescues by Bianchi (2016). Broad-based or "systemic" bailouts are likely to cause fewer distortions in comparison to "idiosyncratic bailouts," which are the result of country-specific decisions. The optimal bailout strategy, however, has not been studied sufficiently in the case of sovereigns, leaving a number of questions for researchers to explore in the future including: how many policy conditions and reforms should be demanded as part of a bailout; whether long-term rescue loans are preferable to short- and medium-term credits, such as the typical three-year IMF programs (e.g. Corsetti, Erce, and Uy 2018); and, the risk sharing benefits of rescue lending (multilateral, regional, or bilateral, see, e.g. Horn 2020).

\subsection{New creditor powers and institutions}

In contrast to research on the IMF or the ESM, there is little work analyzing official lending and international bailouts initiated by emerging market governments, such as China, Saudi Arabia, India, or Russia, despite the fact that these nations play an increasingly important role in today's global financial safety net. "South-to-south” lending flows have been steadily increasing (Broner et al. 2021), including lending between emerging market governments or via new regional financial arrangements, such as the Arab Monetary Fund and the Asian Infrastructure Investment Bank (Scheubel and Stracca 2016).

China, in particular, has emerged as the largest official creditor to developing countries over the past 20 years - even surpassing the total lending portfolio of the World Bank (Figure 12). As discussed by Horn, Reinhart, and Trebesch (2021), almost all of this lending is statecontrolled, meaning that the loans are extended by state-owned banks and other public entities. Moreover, the usual push and pull drivers of international capital flows do not apply in the same way, as China's lending is partly driven by non-commercial motives, such as access to raw materials abroad or by (geo-)political aims.

The rise of China as an international lender is reminiscent of Britain during the $19^{\text {th }}$ century, when London became the "banker to the world", comingling foreign policy and foreign investment objectives (Feis 1930). It also parallels the rise of the United States as a global creditor power in the first half of the $20^{\text {th }}$ century, most famously via its "lend and lease"

\footnotetext{
58 The perverse incentive benefits of international financial bailouts and cooperation also matter in the context of banking crises, which create increasingly large financial spillovers across borders. Fahri and Tirole (2018) find that a government that expects to be bailed out by a foreign country may not sufficiently supervise its domestic banking sector and will tolerate excessive holdings of its sovereign bonds in local banks. These distortions can be reduced by combining a commitment for "solidarity" in cases of crisis with a strong centralized banking supervision. Similarly, Niepmann and Schmidt-Eisenlohr (2013) find that the anticipation of rescue lending from abroad creates incentives to free-ride, resulting in insufficient domestic bank bailouts. It is therefore welfareenhancing for countries to cooperate, either ex-ante or ex-post.
} 
programs and the Marshall plan during and after WWII, which involved large sums of bilateral US lending around the world (Mikesell 1962).

Figure 12: China has become the largest official creditor to developing countries

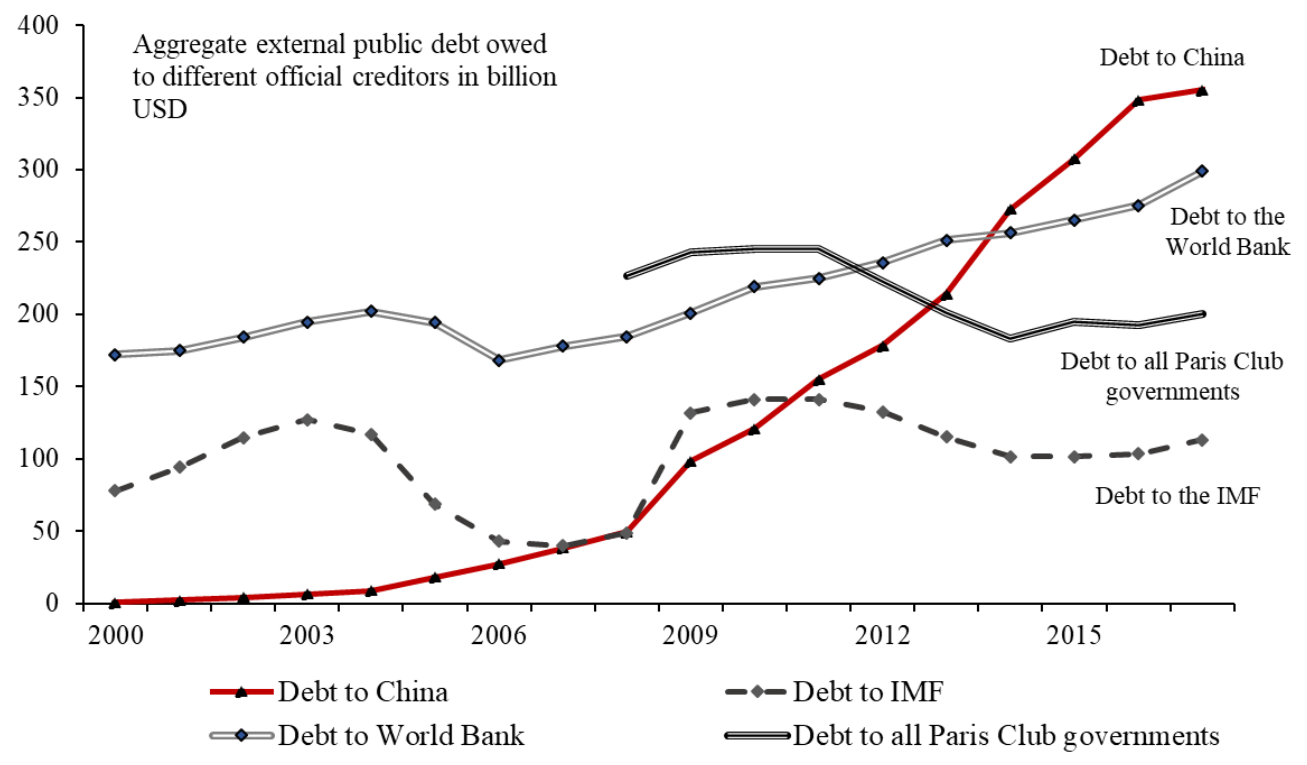

Note: Figure 9 from Horn, Reinhart, and Trebesch (2021). It shows aggregate public debt to different official creditors for all 122 developing and emerging market countries contained in the World Bank International Debt Statistics (excluding China). Debt to all 22 Paris Club governments is taken from the Paris Club website (available since 2008). Debt to China is estimated by Horn, Reinhart, and Trebesch (2021). Debt to the IMF and the World Bank Group (IBRD plus IDA) is from the World Bank's International Debt Statistics.

Alongside the growing volumes of international official lending and cross-border bailouts from treasuries and multilateral organizations, we are also witnessing a return of central bank lending beyond domestic borders in the form of central-bank swap lines. In particular, since 2008, the US Federal Reserve has developed a swap-line network with more than a dozen foreign central banks, allowing participants to obtain short-term (dollar) liquidity. Tooze (2018) and Bahaj and Reis (2018) show that the swap line drawings in 2008 and 2020 played a decisive role in reducing financial market distress and in lowering the cost of dollar funding for banks and firms in recipient countries.

A little-known fact is that the volume of these cross-border emergency dollar loans was substantial, surpassing USD 500 billion in 2008 and USD 400 billion in March 2020. Even less well known is the increasing role of China's central bank as a creditor to foreign countries. As of 2018, the People's Bank of China has signed swap agreements with more than 40 foreign central banks and for drawing rights amounting to USD 550 billion in total (Horn, Reinhart, and Trebesch 2021, Bahaj and Reis 2020). ${ }^{59}$

\footnotetext{
${ }^{59}$ According to Horn, Reinhart and Trebesch (2021), Pakistan, Argentina, Mongolia, Russia, and Turkey have all made use of their standing lines with the PBOC since 2013. For example, as of end-2018 China had extended USD 18.9 billion to Argentina (3 \% of GDP) and USD 1.75 billion to Mongolia (around $15 \%$ of GDP).
} 
Figure 13: Central bank lending across borders, 1815-2015

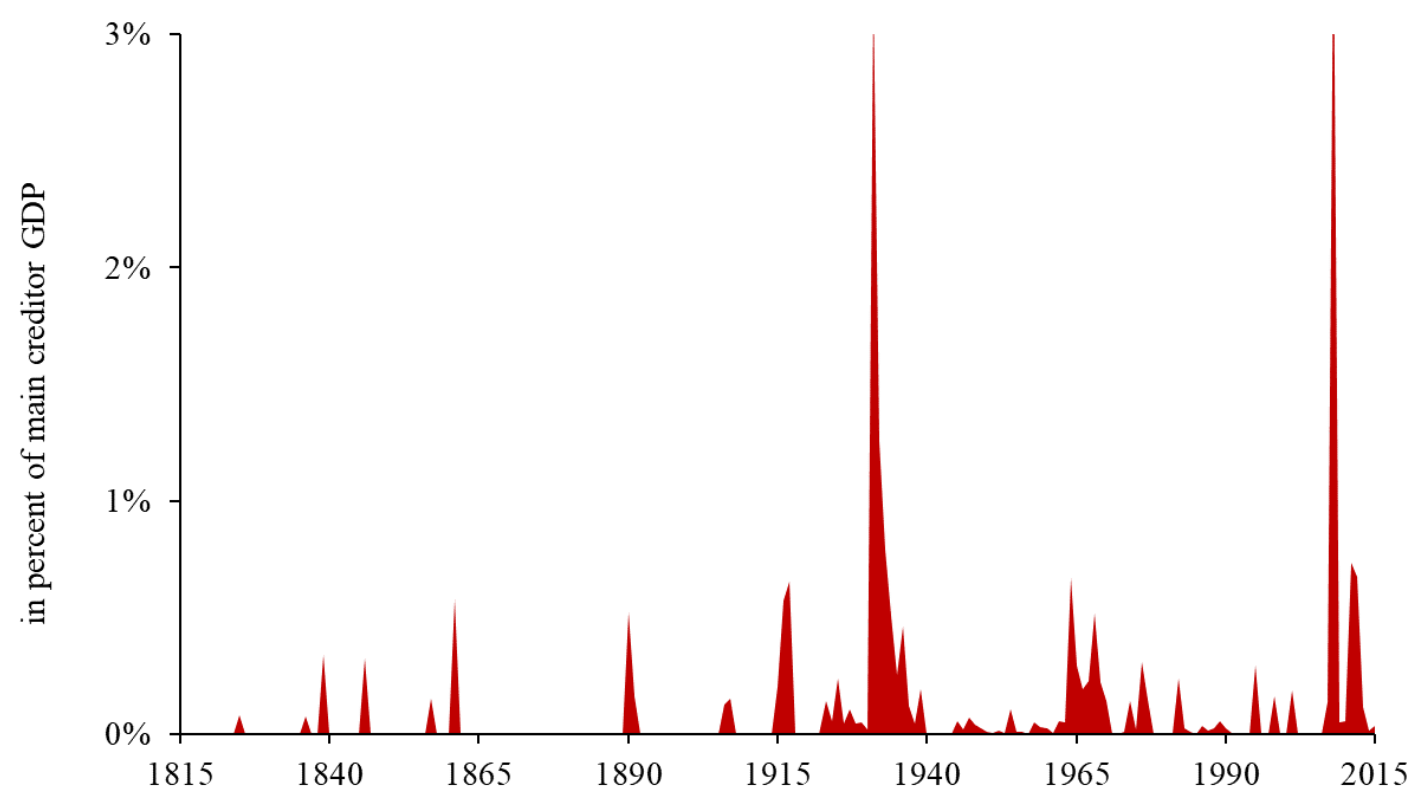

Note: Figure 13 from Horn, Reinhart, and Trebesch (2020) based on ongoing research on cross-border central bank lending since 1815. The data includes central bank short-term credits to foreign central banks as well as bilateral swap line drawings (after WWII), shown in percent of UK GDP until 1914 and in percent of US GDP thereafter.

This type of central bank coordination, however, is nothing new. On the contrary, credit lines and short-term loans between central banks were widespread in the 19th century as well as during the interwar gold standard system and after WWII (Eichengreen 1992, Flandreau 1997, Eichengreen 2008). Moreover, swap lines by the US Federal Reserve were first extended on an ad hoc basis in 1936 and became increasingly institutionalized beginning in the 1960s (Bordo, Humpage, and Schwartz, 2015). And yet, the scale of cross-border central bank lending in 2008 exceeded those periods. This is visible in Figure 13, which shows a time series of overseas central bank lending in percent of British GDP (until 1914) and US GDP thereafter. The 2008 peak exceeds the previous one in 1930-31, when the central banks of Austria, Hungary, Germany, and Britain received large-scale rescue credits in the wake of a sudden stop in private capital flows, domestic bank runs, and increasing pressure on the gold standard system.

In summary, the evidence suggests that we are entering a new era in which official creditors fundamentally shape sovereign debt markets worldwide. The growing influence of official creditors is a partial reversal to the era of official finance and financial repression of the 1950s and 1960s. We are only starting to understand the implications of these developments for governments and private investors alike.

\section{Holdouts and legal risk in sovereign debt markets}

A further global trend in sovereign debt markets with far-reaching consequences is the proliferation of legal risks. The fundamental question of why governments repay is intimately related to the "enforcement technology" available to creditors in the event of a default, which 
ranges from legal sanctions, to "reputational sanctions," and to punishments outside of the debt contracts (Bulow and Rogoff 1989ab; Shleifer 2003; Bolton and Jeanne 2007; Aguiar and Amador 2014). Questions of debt enforcement are critical because, unlike corporations, there is no established bankruptcy regime for sovereigns and because governments have long been protected by the doctrine of "sovereign immunity," which helped to shield public assets from seizure and liquidation.

In this section, we show that sovereign immunity has eroded. We start with a brief discussion on the evolution and characteristics of sovereign debt enforcement over a long horizon. ${ }^{60} \mathrm{We}$ then highlight the increasing risks of disruptive holdouts and litigation strategies in situations of default, which have strengthened creditor bargaining power in the past decade. We conclude by highlighting China's use of new types loan contracts, which appear to have more "teeth" than the sovereign bonds issued in Western capital markets.

\subsection{Enforcement in history: banker collusion, market exclusion, and military threats}

Enforcement technologies have taken different forms throughout history. Their exact form has depended on the relative power of creditors versus debtors, the sources of lending (bankers, markets, other states), and the likelihood of third-party involvement (e.g., international agencies, such as the IMF). In early modern Europe, direct lenders, not markets, financed sovereigns. In this era, the literature has focused particularly on debt enforcement in $16^{\text {th }}$ century Spain under King Philip II. According to Conklin (1998) and Drelichman and Voth (2014) Philip II was a serial defaulter. In their view, the Genoese bankers he defaulted upon so regularly formed a cartel and used collusion and lending moratoria to enforce repayment. Social and monetary sanctions ensured that the merchant-bankers did not lend when the sovereign defaulted, and this mechanism helped to sustain lending to Philip II over many decades. Álvarez-Nogal and Chamley $(2014,2016)$ oppose the view that Philip II was a "borrower from hell” that had to be disciplined through creditor cartels and sanctions. They emphasize, instead, that the King halted payments only on parts of the outstanding debts and that he was cooperative towards his bankers and offered them attractive debt settlements. In this view, Philip II was a partial defaulter who successfully arranged a series of debt renegotiations that opened the door to new lending - reminiscent of the experience with serial debt restructurings of recent decades. $^{61}$

In the $19^{\text {th }}$ century, a variety of sanctions were employed, often resulting in market exclusion, i.e., a "financial embargo" of defaulting countries. First, market conventions at the time prohibited sovereign defaulters to issue bonds on the London Stock Exchange (LSE). This was an important deterrent to defaulting, since the LSE was the primary market for raising funds until the end of the $19^{\text {th }}$ century (Flandreau and Flores 2009, 2012). In addition, Flandreau, Gaillard, and Panizza (2010) show evidence on reputational sanctions via "gatekeeping.” That

\footnotetext{
${ }^{60}$ See Panizza, Sturzenegger, and Zettelmeyer (2009) for an earlier survey on the topic.

${ }^{61}$ See Section 3 on partial default as well as Asonuma (2016) and Graf von Luckner et al. (2021) on serial restructurings.
} 
is, the most reputed investment banks that placed sovereign debt in the $19^{\text {th }}$ century would only deal with sovereigns with a good repayment record, thus punishing defaulters. Military and diplomatic threats were another main enforcement tool in sovereign debt markets of the $19^{\text {th }}$ century, such as the occupation of France after their defeat at Waterloo. ${ }^{62}$ Mitchener and Weidenmier (2010) argue that such "supersanctions" were a credible and powerful enforcement device from the mid- $19^{\text {th }}$ through the early $20^{\text {th }}$ century. ${ }^{63}$ Specifically, they show that the threat of sending gunboats or placing countries under "fiscal house arrest" played a substantial role for government decisions to repay, for crisis resolution, and for the evolution of bond yields. ${ }^{64}$ They find that $64 \%$ of sovereign defaulters experienced supersanctions. Like the story for the French after Waterloo, Mitchener and Weidenmier (2005) find that the threat of military intervention reassured bondholders and lowered the sovereign bond yields, especially of Central American and Caribbean countries. This was due to a notable shift in US foreign policy following the 1904 Roosevelt corollary to the Monroe doctrine, which implied that the US government may intervene militarily in case of default. To show that the threat was credible, the US intervened in Santo Domingo in 1905. Tomz (2007) focuses on understanding the role of reputation and reputational sanctions throughout history, arguing this could have been an additional way of regulating debt during this period.

In the interwar years and in the decades following World War II, the ability of private creditors to impose direct or indirect sanctions weakened. Eichengreen and Portes $(1989,1990)$ and Eichengreen (1991) explain that no effective mechanism existed to exclude defaulting countries from the main international bond market at the time: the New York Stock Exchange. They also show that the involvement of creditor governments in sovereign-debt renegotiation became less frequent and did not yield substantial benefits for private bondholders. Moreover, "the use of military force for debt collection was basically a thing of the past” (Eichengreen and Portes 1989, p. 232). Since the 1990s, rating agencies took over the original role of issuing houses as gatekeepers, but with less teeth (Flandreau, Gaillard, and Packer 2011), while other direct enforcement devices such as legal sanctions and creditor litigation played a limited role, at least until the 1980s (Waibel 2011, Sturzenegger, and Zettelmeyer 2006).

\footnotetext{
${ }^{62}$ In the wake of Waterloo and the signing of the Second Treaty of Paris in November 1815, France's public finances were in shambles. Yet allies were demanding that France pay the costs of the Napoleonic War. In the following ten years, France managed to triple its sovereign borrowing, borrowing at low interest rates that were comparable to the British consol. How did it do so? According to Oosterlinck, Ureche-Rangau, and Vaslin (2014), the threat of military intervention initially guaranteed repayment. Later on, France benefited from reforms it enacted to improve the state of public finance, which reassured markets.

${ }^{63}$ Military sanctions had long been viewed as rare and isolated incidents although probabilities of intervention, conditional on default, were not computed (Lindert and Morton 1989; Lipson 1985).

${ }^{64}$ See, also, the results in Esteves (2013), which emphasizes the role that committees of bondholders can potentially play in regulating debt. A number of follow-up studies provide detailed accounts of the applications of supersanctions during the $19^{\text {th }}$ century. See, for example, Tuncer (2015) on Turkey and Maerean and Sharp (2018) on Southeast Europe.
} 


\subsection{Enforcement today: the erosion of sovereign immunity and the rise of creditor litigation}

In the past 20 years, with the rise of holdout litigation, the threat of market exclusion and creditor sanctions has once again gained prominence. Schumacher, Trebesch, and Enderlein (2015, 2021) document the gradual erosion of sovereign immunity, which was set in motion by the passage of the Foreign Sovereign Immunities Act of 1976 in the U.S. The act adopted a stricter doctrine of immunity for sovereigns, meaning that defaulting sovereigns were no longer shielded against lawsuits in New York. A series of subsequent court decisions in London and New York strengthened the hand of creditors and weakened the available legal defense options of sovereigns. The result was more lawsuits and legal threats, especially since the early 2000s, when specialized distressed debt funds entered the market.

Legal disputes are now a regular consequence of defaults, changing the nature of debt resolution. In the 2000s, half of all sovereign debt restructurings involved legal disputes with creditors, with the cases often stretching on for many years. A typical strategy deployed by distressed debt funds (sometimes called "vulture funds") is to buy up defaulted debt at a deep discount, reject the government's debt restructuring offer, and litigate for full repayment via a lawsuit in London or New York. In addition, litigious creditors often attempt to seize government assets abroad, including commodity exports, central bank assets held in the US, or even presidential airplanes and dinosaur fossils on exhibition. Ultimately, the aim is to force the sovereign into an out-of-court settlement with a handsome payout. Of course, the side effect of this creditor activity can be deadweight losses for the debtor economy, disruption of international trade, and delays in crisis resolution (Benjamin and Wright 2009, Pitchford and Wright 2012).

The recent success of holdout and litigation strategies was apparent after Argentina's 2005 restructuring, which resulted in large-scale holdouts and dozens of lawsuits filed in New York and elsewhere. Most importantly, creditors to Argentina threatened to attach debt repayments to other, non-litigious creditors, by invoking pari passu. According to New York courts, the pari-passu clause implies that sovereign borrowers must pay all creditors "equally and without preference," meaning that holdout creditors must be paid at the same rate as those creditors that participated in a restructuring and accepted a haircut (for details see Gulati and Scott 2012, Cruces and Samples 2016, Buchheit and Gulati 2017). The use of parri passu in sovereign debt contracts dates back to the 1800s, although a minority of bonds issued then contained the clause, and it took until the Elliot vs. Peru judgment in Brussels and the New York decision in 2012 regarding Argentine debt for courts to recognize the clause as meaning differential settlements were not permissible (Chabot and Gulati, 2014). As a consequence of the legal dispute, Argentina has been barred from issuing new external debt for almost 15 years. In 2016, a newly elected government reached a $\$ 10$ billion settlement with creditors holding out, many of whom ended up making double-digit returns on their investment.

A further notable success of holdout creditors was Greece 2012, where almost half of the holders of foreign-law Greek bonds refused to participate in the debt restructuring and were 
fully repaid instead. But Argentina and Greece are not outliers, as shown in Schumacher, Trebesch, and Enderlein (2018) and Fang, Schumacher, and Trebesch (2020). Legal threats and holdout tactics played a significant role in almost all recent debt crises, including in Ukraine 2015 and in the ongoing defaults of Lebanon and Venezuela (see also Buchheit and Gulati 2017).

Moreover, recent research shows that creditor litigation is costly ex-post. For example, creditorfriendly judgments in the Argentina lawsuit caused a significant decline of Argentine bond and stock prices (Ahmed and Alfaro 2017, Hebert and Schreger 2017). In addition, Schumacher, Trebesch, and Enderlein (2021) show that litigation is associated with a loss of market access for debtor countries. Since the early 2000s, no sovereign was able to tap international bond markets while at the same time facing the legal threat of asset seizures through foreign courts. Relatedly, Buchheit, Gulati, and Tirado (2013) argue that, during the euro crisis, concerns about holdouts and litigation (the risk of "ending up like Argentina") increased the willingness of policy makers to pay bondholders in full and instead arrange large-scale sovereign bailouts, e.g., in Portugal or Ireland.

These trends suggest that sovereign debt is becoming more enforceable and that litigation is a relevant cost of default. Foreign courts increasingly act as a third-party enforcement mechanism, in the spirit of classic sovereign debt theory (e.g., Bulow and Rogoff, 1989b). They can explicitly or implicitly impose an embargo on new borrowing or block debt repayments on performing bonds. This interpretation helps to bridge two strands of the sovereign debt literature, namely the "reputation view," suggesting that governments repay because of the threat of exclusion from credit markets and output losses, and the "sanctions view," according to which repayment occurs due to the threat of sanctions. The risk of litigation combines both elements - a legal sanction resulting in lost market access.

Broner, Martin, and Ventura (2010) add an additional perspective on enforcement power in recent decades. Since foreign creditors can sell their bonds to domestic creditors, who have electoral leeway over their governments, they argue that secondary markets act as an enforcement device in modern democracies. Arguably, this political-economy channel worked less well in the $19^{\text {th }}$ century, with limited enfranchisement and relatively less sovereign debt issued in domestic capital markets (in part due to less developed financial institutions).

How do the developments fit in a longer historical perspective? One way to interpret recent trends is that enforcement technologies are returning to their long-run equilibrium after a few decades of decline and stagnation. On the one hand, if the shift towards stronger creditor rights persists, it could be beneficial for sovereign debt markets, as it may act as a disciplining device that limits overborrowing and facilitates quicker restructurings (e.g., Shleifer 2003, Pitchford and Wright 2012). That said, it is far from clear whether the recent creditor successes will prove long-lasting and robust, given UK and US court systems are based on case-law traditions and continuously evolve. This puts creditors' most effective weapon, pari passu, at risk. In addition, new policy initiatives will help to reduce the likelihood of holdouts and litigation, in particular 
the introduction of enhanced collective action clauses in newly-issued sovereign bonds (e.g. Carletti et al. 2020), the G20 Debt Service Suspension Initiative and its possible successors (e.g. Lang, Mihaliy and Presibtero 2020), and the IMF and World Bank's "Common Framework," which is designed to foster burden sharing between private and official creditors (Bolton et al. 2020, IMF 2021). Despite these measures, in the short and medium run, holdout risks in sovereign bond restructurings are likely to remain elevated, making the resolution of debt crises more difficult (Bolton and Jeanne 2007).

Looking ahead, the most important legal developments for international sovereign lending and its enforcement may not arise in New York, but in rising creditor powers such as China, India or Russia. For example, Gelpern et al. (2021) show that Chinese state-owned banks that lend to developing countries use "hybrid" contracts that combine elements of private and official finance. The contracts contain "No Paris Club" clauses to achieve seniority over other official creditors, novel collateral arrangements (such as lender-controlled cash accounts), and cancellation and cross-default clauses that give the Chinese lenders considerable discretion to ask for immediate repayment, e.g., in case of diplomatic disagreement.

\section{Conclusion}

The Great Recession and the eurozone debt crisis inspired a wave of empirical and theoretical research on sovereign debt, rivaling the volume of scholarship after the Latin American debt crisis of the 1980s. It reinvigorated work on classic questions, such as the reasons for sovereign lending and default, the costs of default, on debt workouts and on debt sustainability. Scholars have poured these "old wines" into new bottles, often looking for underappreciated or overlooked elements, such as the transmission of sovereign risk to firms and how that, in turn, affects investment and output. It also spurred work on "new wines” or features of crises, perhaps most importantly sovereign-bank "doom loops" and the increasing financialization of the global economy. Our survey has highlighted features that are idiosyncratic to the eurozone debt crisis, such as the role of monetary unions for borrowing and default decisions, but also emerging trends that happened to coincide in timing with it.

In both advanced and emerging economies, debt sustainability will remain a major concern that is intimately linked to the level of interest rates. Should yields on government bonds remain close to their current historic lows, we may enter an extended period of "debt without drama," meaning high and rising debt-to-GDP ratios but manageable debt servicing costs that are close to their historical long-run average. However, if interest rates were to reverse again, as in the 1960s and 1970s or as in the Eurozone periphery after 2009, widespread sovereign debt distress is a more likely scenario.

Sovereign debt markets in the $21^{\text {st }}$ century will also be shaped by the renewed importance of official creditors and by the rise of "South to South" lending. Since 2008, central banks have again become the largest holders of government bonds in many countries; cross-border sovereign bailout lending have reached new records; and international central bank "swap lines” 
have become a proven crisis response tool. Official finance also plays a big role for rising creditor powers such as China. These "Southern" creditors are lending large sums to foreign governments via state-owned banks and using new types of debt contracts that blend elements of official and private finance.

Another important trend is the rise of domestic debt issuance. As more EME governments place their debt domestically, and the debt is often sold to domestic banks, the challenge of banksovereign linkages will likely matter to emerging markets as well in the coming decades. It also appears that the risk of holdouts and increased litigation will not be subsiding, as enforcement options for creditors are stronger than they have been in a very long time, in both advanced and emerging economies. In sum, many of the features of developing-country debt markets and crises also apply to advanced countries. The same is also true for the lessons of the eurozone crisis, which have relevance for an emerging-market world that is becoming richer, more financialized, and endowed with increasingly powerful central banks.

In terms of research methods, the literature of the past decade demonstrates that, in addition to important theoretical advances, empirical methods have improved, drawing from applied microeconomics and increasingly relying on state-of-the art research design for causal identification. There are promising developments that combine micro-based sovereign debt models with heterogeneous creditors and firms that can be tested using large-scale, micro-level data. Looking ahead, opportunities will emerge from the development of rich new datasets with tens of thousands of bonds and banks or from going back far in time. The field of international finance could witness an "empirical revolution" similar to that in international trade.

More generally, we show that a historical perspective offers valuable lessons for present and future challenges in the sovereign debt market. During the past 200 years, there were major shifts in the institutions governing this market as well as in the types of lenders participating in it (official versus private, domestic versus foreign, or bank versus bond debt). While the shapes and colors have changed, many of the fundamental issues are still the same - in particular, the "eternal” government trade-off between repaying and defaulting, the uncertainty over what happens when countries default, and the repeated boom and bust cycles in lending by creditors.

Many questions and puzzles remain, suggesting some directions for future research. How will advanced and developing country governments deal with the large public debt burdens going forward? How much more debt can the market absorb given that the level of public indebtedness is already at historic highs? What are the implications of the expanding central bank holdings and growing sovereign bailouts by official creditors? In case of future turmoil, will selffulfilling panics, rollover crises and bank-sovereign "doom loops” become more pertinent? And, last but not least, what are the consequences of the rise of China and other emerging powers for global debt markets in the decades to come? 


\section{References}

Acemoglu, Daron, Simon Johnson, James Robinson, and Yunyong Thaicharoen. 2003. "Institutional Causes, Macroeconomic Symptoms: Volatility, Crises and Growth.” Journal of Monetary Economics 50 (1): 49-123.

Acharya, Viral V., and Raghuram G. Rajan. 2013. "Sovereign Debt, Government Myopia, and the Financial Sector.” Review of Financial Studies 26 (6): 1526-60.

Acharya, Viral V., and Sascha Steffen. 2015. “The 'Greatest' Carry Trade Ever? Understanding Eurozone Bank Risks.” Journal of Financial Economics 115 (2): 215-36.

Acharya, Viral V., Diane Pierret, and Sascha Steffen. 2018. "Lender of Last Resort versus Buyer of Last Resort - Evidence from the European Sovereign Debt Crisis." Swiss Finance Institute Research Paper 18-35.

Acharya, Viral V., Tim Eisert, Christian Eufinger, and Christian Hirsch. 2018. "Real Effects of the Sovereign Debt Crisis in Europe: Evidence from Syndicated Loans.” Review of Financial Studies 31 (8): 2855-96.

Acharya, Viral V., Itamar Drechsler, and Philipp Schnabl. 2014. “A Pyrrhic Victory? Bank Bailouts and Sovereign Credit Risk.” Journal of Finance 69 (6): 2689-2739.

Aguiar, Mark, and Gita Gopinath. 2006. "Defaultable debt, interest rates and the current account," Journal of International Economics 69 (1): 64-83.

Aguiar, Mark, and Manuel Amador. 2014. "Sovereign Debt." In Handbook of International Economics, edited by Gita Gopinath, Elhanan Helpman, and Kenneth Rogoff, 4:647-87. New York and North-Holland: Elsevier.

Aguiar, Mark, and Manuel Amador. 2021. The Economics of Sovereign Debt and Default. Princeton University Press.

Aguiar, Mark, Manuel Amador, and Gita Gopinath. 2009. “Investment Cycles and Sovereign Debt Overhang.” Review of Economic Studies 76 (1): 1-31.

Aguiar, Mark, Manuel Amador, Emmanuel Farhi, and Gita Gopinath. 2015. "Coordination and Crisis in Monetary Unions.” Quarterly Journal of Economics 130 (4): 1727-79.

Aguiar, Mark, Satyajit Chatterjee, Harold L. Cole, and Zachary Stangebye. 2016. "Quantitative Models of Sovereign Debt Crises.” In Handbook of Macroeconomics, edited by John B. Taylor and Harald Uhlig, 2:1697-1755. New York and North-Holland: Elsevier.

Ahmed, Faisal Z., and Laura Alfaro. 2017. "Market Reactions to Sovereign Litigation.” Capital Markets Law Journal 12 (2): 141-63.

Aizenman, Joshua, and Nancy Marion. 2011. “Using Inflation to Erode the US Public Debt.” Journal of Macroeconomics 33 (4): 524-41.

Alesina, Alberto, and Andrea Passalacqua. 2016. “The Political Economy of Government Debt.” In Handbook of Macroeconomics, edited by John B. Taylor and Harald Uhlig, 2599-2651. New York and North-Holland: Elsevier.

Alesina, Alberto, and Guido Tabellini. 1990. "A Positive Theory of Fiscal Deficits and Government Debt.” Review of Economic Studies 57 (3): 403-14.

Alfaro, Laura, Sebnem Kalemli-Ozcan, and Vadym Volosovych. 2014. "Sovereigns, Upstream Capital Flows, and Global Imbalances.” Journal of the European Economic Association 12 (5): 1240-84.

Almeida, Heitor, Igor Cunha, Miguel Ferreira, and Felipe Restrepo. "The Real Effects of Credit Ratings: The Sovereign Ceiling Channel”. The Journal of Finance 72(1): 249-290.

Altavilla, Carlo, Marco Pagano, and Saverio Simonelli. 2017. "Bank Exposures and Sovereign Stress Transmission.” Review of Finance 21 (6): 2103-39.

Álvarez-Nogal, Carlos, and Christophe Chamley. 2014. "Debt Policy under Constraints: Philip II, the Cortes, and Genoese Bankers.” Economic History Review 67 (1): 192-213. 
Álvarez-Nogal, Carlos, and Christophe Chamley. 2016. "Philip II Against the Cortes and the Credit Freeze of 1575-1577.” Journal of Iberian and Latin American Economic History 34 (3): 35182.

Ams, Julianne, Reza Baqir, Anna Gelpern, and Christoph Trebesch. 2019. "Sovereign Default.” In Sovereign Debt: A Guide for Economists and Practitioners, edited by S. Ali Abbas, Alex Pienkowski, and Kenneth Rogoff, Oxford: Oxford University Press.

Ang, Andrew, and Francis A. Longstaff. 2013. "Systemic Sovereign Credit Risk: Lessons from the U.S. and Europe.” Journal of Monetary Economics 60 (5): 493-510.

Arellano, Cristina. 2008. "Default Risk and Income Fluctuations in Emerging Economies." American Economic Review 98 (3): 690-712.

Arellano, Cristina, Yan Bai, and Luigi Bocola. 2019. "Sovereign Default Risk and Firm Heterogeneity.” NBER Working Paper 23314.

Arellano, Cristina, Xavier Mateos-Planas, and José-Víctor Ríos-Rull. 2019. "Partial Default," NBER Working Paper 26076.

Arslanalp, Serkan, and Takahiro Tsuda. 2014. "Tracking Global Demand for Advanced Economy Sovereign Debt.” IMF Economic Review 62 (3): 430-64.

Arteta, Carlos, and Galina Hale. 2008. "Sovereign Debt Crises and Credit to the Private Sector." Journal of International Economics 74 (1): 53-69.

Asatryan, Zareh, César Castellón, and Thomas Stratmann. 2018. "Balanced budget rules and fiscal outcomes: Evidence from historical constitutions," Journal of Public Economics, 167: 105-119.

Asonuma, Tamon. 2016. "Serial Sovereign Defaults and Debt Restructurings." IMF Working Paper 2016/066.

Asonuma, Tamon, and Christoph Trebesch. 2016. "Sovereign Debt Restructurings: Preemptive or Post-Default.” Journal of the European Economic Association 14 (1): 175-214.

Asonuma, Tamon, Marcos d Chamon, Aitor Erce, and Akira Sasahara. 2019. "Costs of Sovereign Defaults: Restructuring Strategies, Bank Distress and the Capital Inflow-Credit Channel.” IMF Working Paper 19/69.

Bacchetta, Philippe, Elena Perazzi, and Eric van Wincoop. 2018. "Self-Fulfilling Debt Crises: What Can Monetary Policy Do?” Journal of International Economics 110: 119-34.

Bahaj, Saleem. 2020. "Sovereign Spreads in the Euro Area: Cross Border Transmission and Macroeconomic Implications.” Journal of Monetary Economics 110: 116-35.

Bahaj, Saleem, and Ricardo Reis. 2018. "Central Bank Swap Lines.” CESifo Working Paper Series 7124.

Bahaj, Saleem, and Ricardo Reis. 2020. "Jumpstarting an International Currency." CEPR Discussion Paper 14793.

Balteanu, Irina, and Aitor Erce. 2018. "Linking Bank Crises and Sovereign Defaults: Evidence from Emerging Markets.” IMF Economic Review 66 (4): 617-64.

Barkbu, Bergljot, Barry Eichengreen, and Ashoka Mody. 2012. "Financial Crises and the Multilateral Response: What the Historical Record Shows." Journal of International Economics 88 (2): 422-35.

Barro, Robert J. 1979. “On the Determination of the Public Debt.” Journal of Political Economy 87 (5): 940-71.

Bauer, Michael, and Glenn Rudebusch. 2020. "Interest Rates under Falling Stars," American Economic Review 110(5): 1316-1354.

Benjamin, David, and Mark L. J. Wright. 2009. "Recovery Before Redemption? A Theory of Delays in Sovereign Debt Renegotiations.” Unpublished.

Bernal, Oscar, Kim Oosterlinck, and Ariane Szafarz. 2010. “Observing Bailout Expectations during a Total Eclipse of the Sun.” Journal of International Money and Finance 29: 1193-1205

Bi, Huixin. 2012. "Sovereign Default Risk Premia, Fiscal Limits, and Fiscal Policy.” European Economic Review 56 (3): 389-410. 
Bianchi, Javier. 2016. “Efficient Bailouts?” American Economic Review 106 (12): 3607-59.

Bianchi, Javier, and Jorge Mondragon. 2018. “Monetary Independence and Rollover Crises.” NBER Working Paper 25340.

Blanchard, Olivier J. 1990. "Suggestions for a New Set of Fiscal Indicators.” OECD Economics Department Working Papers 79.

Blanchard, Olivier J. 2019. "Public Debt and Low Interest Rates.” American Economic Review 109 (4): 1197-1229.

Bocola, Luigi, and Alessandro Dovis 2019. "Self-Fulfilling Debt Crises: A Quantitative Analysis,” American Economic Review, 109(12): 4343-4377.

Bocola, Luigi. 2016. “The Pass-Through of Sovereign Risk.” Journal of Political Economy 124 (4): 879-926.

Bofondi, Marcello, Luisa Carpinelli, and Enrico Sette. 2018. "Credit Supply During a Sovereign Debt Crisis.” Journal of the European Economic Association 16 (3): 696-729.

Bohn, Henning. 1998. "The Behavior of U. S. Public Debt and Deficits." Quarterly Journal of Economics 113 (3): 949-63.

Bolton, Patrick, and Olivier Jeanne. 2007. "Structuring and Restructuring Sovereign Debt: The Role of a Bankruptcy Regime.” Journal of Political Economy 115 (6): 901-24.

Bolton, Patrick, and Olivier Jeanne. 2011. "Sovereign Default Risk and Bank Fragility in Financially Integrated Economies.” IMF Economic Review 59 (2): 162-94.

Bolton, Patrick, Lee C. Buchheit, Pierre-Olivier Gourinchas, Mitu Gulati, Chang-Tai Hsieh, Ugo Panizza, and Beatrice Weder di Mauro. 2020. "Born Out of Necessity: A Debt Standstill for COVID-19.” CEPR Policy Insight 103.

Borchard, Edwin, and William H. Wynne. 1951. State Insolvency and Foreign Bondholders. Washington, D.C.: Beard Books.

Bordo, Michael D, Owen F. Humpage, and Anna J. Schwartz. 2015. "The Evolution of the Federal Reserve Swap Lines since 1962.” IMF Economic Review 63 (2): 353-72.

Bordo, Michael D., and Anna J. Schwartz. 1999. "Under What Circumstances, Past and Present, Have International Rescues of Countries in Financial Distress Been Successful?” Journal of International Money and Finance 18 (4): 683-708.

Bordo, Michael D., and Christopher M. Meissner. 2016. “Fiscal and Financial Crises.” NBER Working Paper 22059.

Bordo, Michael D., Christopher M. Meissner, and David Stuckler. 2010. "Foreign Currency Debt, Financial Crises and Economic Growth: A Long-Run View.” Journal of International Money and Finance 29 (4): 642-65.

Bordo, Michael, Barry Eichengreen, Daniela Klingebiel, and Maria Soledad Martinez-Peria. 2001. "Is the Crisis Problem Growing More Severe?" Economic Policy 16 (32): 52-82.

Borensztein, Eduardo, and Ugo Panizza. 2009. “The Costs of Sovereign Default.” IMF Staff Papers 56 (4): 683-741.

Bottero, Margherita, Simone Lenzu, and Filippo Mezzanotti. 2020. "Sovereign Debt Exposure and the Bank Lending Channel: Impact on Credit Supply and the Real Economy." Journal of International Economics 126: 103328.

Broner, Fernando, Tatiana Didier, Sergio Schmuckler, and Goetz von Peter. 2021. "Bilateral International Investments: The Big Sur?” World Bank Policy Research Working Paper 9501.

Broner, Fernando, Aitor Erce, Alberto Martin, and Jaume Ventura. 2014. "Sovereign Debt Markets in Turbulent Times: Creditor Discrimination and Crowding-out Effects.” Journal of Monetary Economics 61: 114-42.

Broner, Fernando A., Guido Lorenzoni, and Sergio L. Schmukler. 2013. "Why Do Emerging Economies Borrow Short Term?” Journal of the European Economic Association 11 (1): 67100. 
Broner, Fernando, Alberto Martin, and Jaume Ventura. 2010. "Sovereign Risk and Secondary Markets.” American Economic Review 100 (4): 1523-55.

Broner, Fernando, and Jaume Ventura. 2016. "Rethinking the Effects of Financial Globalization.” Quarterly Journal of Economics 131 (3): 1497-1542.

Brunnermeier, Markus K., Luis Garicano, Philip R. Lane, Marco Pagano, Ricardo Reis, Tano Santos, David Thesmar, Stijn Van Nieuwerburgh, and Dimitri Vayanos. 2016. "The Sovereign-Bank Diabolic Loop and ESBies.” American Economic Review 106 (5): 508-12.

Brunnermeier, Markus K., and Ricardo Reis. 2019. "A Crash Course on the Euro Crisis.” NBER Working Paper 26229.

Brutti, Filippo. 2011. "Sovereign Defaults and Liquidity Crises." Journal of International Economics 84 (1): 65-72.

Brutti, Filippo, and Philip Sauré. 2015. “Transmission of Sovereign Risk in the Euro Crisis.” Journal of International Economics 97 (2): 231-48.

Brutti, Filippo, and Philip Sauré. 2016. "Repatriation of Debt In The Euro Crisis.” Journal of the European Economic Association 14 (1): 145-74.

Buchheit, Lee C., and G. Mitu Gulati. 2017. "Restructuring Sovereign Debt after NML v Argentina.” Capital Markets Law Journal 12 (2): 224-38.

Buchheit, Lee C., G. Mitu Gulati, and Ignacio Tirado. 2013. "The Problem of Holdout Creditors in Eurozone Sovereign Debt Restructurings.” Unpublished.

Buchheit, Lee C., and Mitu Gulati. 2018 "Use of the Local Law Advantage in the Restructuring of European Sovereign Bonds.” Unpublished.

Bulow, Jeremy, and Kenneth Rogoff. 1989a. “Sovereign Debt: Is to Forgive to Forget?” American Economic Review 79 (1): 43-50.

Bulow, Jeremy, and Kenneth Rogoff. 1989b. “A Constant Recontracting Model of Sovereign Debt.” Journal of Political Economy 97 (1): 155-78.

Burger, John D., and Francis E. Warnock. 2006. “Local Currency Bond Markets.” IMF Staff Papers 53: $1-7$.

Calvo, Guillermo A. 1988. "Servicing the Public Debt: The Role of Expectations." American Economic Review 78 (4): 647-61.

Caprio, Gerard Jr., and Daniela Klingebiel. 2003. "Episodes of Systematic and Borderline Financial Crises." Unpublished.

Carletti, Elena, Paolo Colla, G. Mitu Gulati, and Steven Ongena. 2020. “The Price of Law: The Case of the Eurozone Collective Action Clauses.” Swiss Finance Institute Research Paper 17-35.

Catão, Luis A. V., and Gian M. Milesi-Ferretti. 2014. "External Liabilities and Crises.” Journal of International Economics 94 (1): 18-32.

Catão, Luis A. V., and Rui C. Mano. 2017. “Default Premium.” Journal of International Economics 107 (C): 91-110.

Cecchetti, Stephen G., Madhusudan S. Mohanty, and Fabrizio Zampolli. 2010. "The Future of Public Debt: Prospects and Implications.” BIS Working Paper 300.

Cecchetti, Stephen G., Madhusudan S. Mohanty, and Fabrizio Zampolli. 2011. "The Real Effects of Debt.” BIS Working Paper 352.

Chabot, Benjamin, and Mitu Gulati. 2014. "Santa Anna and His Black Eagle: The Origins of Pari Passu?” Capital Markets Law Journal 9 (3): 216-41.

Chamon, Marcos, Julian Schumacher, and Christoph Trebesch. 2018. "Foreign-Law Bonds: Can They Reduce Sovereign Borrowing Costs?” Journal of International Economics 114 (C): 16479.

Chari, Anusha, Ryan Leary, and Toan Phan 2018. "The Transmission of Quasi-Sovereign Default Risk: Evidence from Puerto Rico.” Unpublished.

Chari, V. V., Alessandro Dovis, and Patrick J. Kehoe. 2020. “On the Optimality of Financial Repression.” Journal of Political Economy 128 (2): 710-39. 
Checherita-Westphal, Cristina, and Philipp Rother. 2012. “The Impact of High Government Debt on Economic Growth and Its Channels: An Empirical Investigation for the Euro Area.” European Economic Review 56 (7): 1392-1405.

Chernov, Mikhail, Lukas Schmid, and Andres Schneider. forthcoming. "A Macrofinance View of U.S. Sovereign CDS Premiums.” Journal of Finance.

Clarke, Hyde. 1878. "On the Debts of Sovereign and Quasi-Sovereign States, Owing by Foreign Countries.” Journal of the Statistical Society of London 41: 299-347.

Cline, William R. 1995. International Debt Reexamined. Washington: Institute for International Economics

Cohen, Daniel, and Jeffrey Sachs. 1986. "Growth and External Debt under Risk of Debt Repudiation.” European Economic Review 30 (3): 529-60.

Cohen, Daniel, and Sébastien Villemot. 2015. "Endogenous Debt Crises.” Journal of International Money and Finance 51: 337-69.

Cole, Harold L., James Dow, and William B. English. 1995. "Default, Settlement, and Signaling: Lending Resumption in a Reputational Model of Sovereign Debt.” International Economic Review 36(2): 365-385.

Cole, Harold L., and Timothy J. Kehoe. 1996. “A Self-Fulfilling Model of Mexico’s 1994-1995 Debt Crisis.” Journal of International Economics 41 (3-4): 309-30.

Cole, Harold L., and Timothy J. Kehoe. 2000. “Self-Fulfilling Debt Crises.” The Review of Economic Studies 67 (1): 91-116.

Collard, Fabrice, Michel Habib, and Jean-Charles Rochet. 2015. "Sovereign Debt Sustainability in Advanced Economies.” Journal of the European Economic Association 13 (3): 381-420.

Conesa, Juan Carlos, and Timothy J. Kehoe. 2015. "Gambling for Redemption and Self-Fulfilling Debt Crises.” NBER Working Paper 21026.

Conklin, James. 1998. "The Theory of Sovereign Debt and Spain under Philip II," Journal of Political Economy 106(3): 483-513,

Corsetti, Giancarlo, Aitor Erce, and Timothy Uy. 2018. "Debt Sustainability and the Terms of Official Support.” Cambridge Working Papers in Economics 1864.

Corsetti, Giancarlo, and Luca Dedola. 2016. "The Mystery of the Printing Press: Monetary Policy and Self-Fulfilling Debt Crises.” Journal of the European Economic Association 14 (6): 132971.

Corsetti, Giancarlo, Keith Kuester, André Meier, and Gernot J. Müller. 2012. "Sovereign Risk, Fiscal Policy, and Macroeconomic Stability.” Economic Journal 123 (566): 99-132.

Corsetti, Giancarlo, Keith Kuester, André Meier, and Gernot J. Müller. 2014. "Sovereign Risk and Belief-Driven Fluctuations in the Euro Area.” Journal of Monetary Economics 61: 53-73.

Cottarelli, Carlo, Paolo Mauro, Lorenzo Forni, and Jan Gottschalk. 2010. "Default in Today's Advanced Economies; Unnecessary, Undesirable, and Unlikely.” IMF Staff Position Notes.

Cruces, Juan J., and Christoph Trebesch. 2013. "Sovereign Defaults: The Price of Haircuts." American Economic Journal: Macroeconomics 5 (3): 85-117.

Cruces, Juan J., and Tim R. Samples. 2016. “Settling Sovereign Debt’s Trial of the Century.” Emory International Law Review 31 (1).

D’Amico, Stefania, William English, David López-Salido, and Edward Nelson. 2012. "The Federal Reserve's Large-scale Asset Purchase Programmes: Rationale and Effects.” Economic Journal 122 (564): 415-46.

D’Erasmo, Pablo, Enrique G. Mendoza, and Jing Zhang. 2016. "What is a Sustainable Public Debt.” In Handbook of Macroeconomics, John B. Taylor and Harald Uhlig (eds.), vol. 2. North Holland, Amsterdam: 2493-2597.

D’Erasmo, Pablo, and Enrique G. Mendoza. 2018. "History Remembered: Optimal Sovereign Default on Domestic and External Debt.” NBER Working Paper 25073. 
Das, Udaibir S., Michael G. Papaioannou, and Christoph Trebesch. 2010. “Sovereign Default Risk and Private Sector Access to Capital in Emerging Markets.” IMF Working Paper 10/10.

Das, Udaibir, Michael Papaioannou, and Christoph Trebesch. 2012. "Sovereign Debt Restructurings 1950-2010; Literature Survey, Data, and Stylized Facts," IMF Working Paper 12/203.

De Grauwe, Paul. 2012. "The Governance of a Fragile Eurozone.” Australian Economic Review 45 (3): 255-68.

De Grauwe, Paul, and Yuemei Ji. 2013. "Self-Fulfilling Crises in the Eurozone: An Empirical Test.” Journal of International Money and Finance 34: 15-36.

De Marco, Filippo, and Marco Macchiavelli. 2016. "The Political Origin of Home Bias: The Case of Europe.” Finance and Economics Discussion Series 2016-060.

De Santis, Roberto A. 2019. “Redenomination Risk.” Journal of Money, Credit and Banking 51 (8): 2173-2206.

Del Negro, Marco, Domenico Giannone, Marc Giannoni, and Andrea Tambalotti. 2019. "Global Trends in Interest Rates," Journal of International Economics 118(C): 248-262.

Dell'Ariccia, Giovanni, Isabel Schnabel, and Jeromin Zettelmeyer. 2006. "How Do Official Bailouts Affect the Risk of Investing in Emerging Markets?” Journal of Money, Credit and Banking 38 (7): 1689-1714.

Dell'Erba, Salvatore, Ricardo Hausmann, and Ugo Panizza. 2013. "Debt Levels, Debt Composition, and Sovereign Spreads in Emerging and Advanced Economies." Oxford Review of Economic Policy 29 (3): 518-47.

Dellas, Harris, and Dirk Niepelt. 2016. “Sovereign Debt with Heterogeneous Creditors.” Journal of International Economics 99: 16-26.

Doerr, Sebastian, Stefan Gissler, Jose-Luis Peydro, and Hans-Joachim Voth. 2019. "From Finance to Fascism: The Real Effect of Germany’s 1931 Banking Crisis.” CEPR DP 12806.

Dovis, Alessandro, and Rishabh Kirpalani. 2020. "Fiscal Rules, Bailouts, and Reputation in Federal Governments.” American Economic Review 110 (3): 860-88.

Drechsel, Thomas, and Silvana Tenreyro. 2018. "Commodity Booms and Busts in Emerging Economies.” Journal of International Economics 112: 200-218.

Drelichman, Mauricio, and Hans-Joachim Voth. 2014. Lending to the Borrower from Hell: Debt, Taxes, and Default in the Age of Philip II. Princeton and Oxford: Princeton University Press.

Du, Wenxin, and Jesse Schreger. 2016. "Local Currency Sovereign Risk," Journal of Finance 71(3): 1027-70.

Du, Wenxin, Carolin E. Pflueger, and Jesse Schreger, forthcoming. "Sovereign Debt Portfolios, Bond Risks, and the Credibility of Monetary Policy.” Journal of Finance, forthcoming

Eaton, Jonathan, and Mark Gersovitz. 1981. "Debt with Potential Repudiation: Theoretical and Empirical Analysis.” The Review of Economic Studies 48 (2): 289-309.

Eaton, Jonathan, and Raquel Fernandez. 1995. "Sovereign Debt.” In Handbook of International Economics, Volume 3, edited by Kenneth Rogoff and Gene M. Grossman, 2031-77, New York and North-Holland: Elsevier.

Eberhardt, Markus, and Andrea Presbitero. 2015. "Public Debt and Growth: Heterogeneity and Nonlinearity.” Journal of International Economics 97 (1): 44-58.

Edwards, Sebastian, Francis A. Longstaff, and Alvaro Garcia Marin. 2015. "The U.S. Debt Restructuring of 1933: Consequences and Lessons.” NBER Working Paper 21694.

Edwards, Sebastian. 2018. American Default: The Untold Story of FDR, the Supreme Court, and the Battle over Gold. Princeton: Princeton University Press.

Eichengreen, Barry J. 1991. "Historical Research on International Lending and Debt.” Journal of Economic Perspectives 5 (2): 149-169.

Eichengreen, Barry J. 1992. Golden Fetters: The Gold Standard and the Great Depression, 19191939. New York: Oxford University Press. 
Eichengreen, Barry J. 2008. Globalizing Capital: A History of the International Monetary System. Princeton: Princeton University Press.

Eichengreen, Barry J., and Ricardo Hausmann. 1999. "Exchange Rates and Financial Fragility.” NBER Working Paper 7418.

Eichengreen, Barry J., and Richard Portes. 1986. "Debt and Default in the 1930s: Causes and Consequences.” European Economic Review 30 (3): 599-640.

Eichengreen, Barry J., and Richard Portes, 1989. "Dealing With Debt: The 1930s and the 1980s," In Dealing with the Debt Crisis, edited by Ishrat Husain and Ishac Diwan, 69-86. Washington, DC: The World Bank.

Eichengreen, Barry J., and Richard Portes. 1990. "The Interwar Debt Crisis and Its Aftermath," World Bank Research Observer 5 (1): 69-94.

Eichengreen, Barry, Ricardo Hausmann, and Ugo Panizza. 2005. “The Mystery of Original Sin.” In Other People's Money: Debt Denomination and Financial Instability in Emerging-Market Economies, edited by Barry Eichengreen and Ricardo Hausmann, 233-65. Chicago: University of Chicago Press.

Ellison, Martin, and Andrew Scott. 2020. “Managing the UK National Debt 1694-2018.” American Economic Journal: Macroeconomics 12 (3): 227-57.

Engel, Charles, and Jungjae Park. 2018. "Debauchery and Original Sin: The Currency Composition of Sovereign Debt.” NBER Working Paper 24671.

Engler, Philipp, and Christoph Große Steffen. 2016. "Sovereign Risk, Interbank Freezes, and Aggregate Fluctuations.” European Economic Review 87: 34-61.

Erce, Aitor, and Enrico Mallucci. 2018. "Selective Sovereign Defaults.” International Finance

Discussion Papers 1239.Erce, Aitor, Enrico Mallucci and Mattia Picarelli. 2021. "A Journey in the History of Sovereign Defaults on Domestic Law Public Debt.” Unpublished.

Esteves, Rui. 2011. "The Future of the Past" (April 8) https://theportugueseeconomy.blogspot.com/2011/04/future-of-past.html.

Esteves, Rui. 2013. "The bondholder, the overeign, and the banker: sovereign debt and bondholders' protection before 1914.” European Review of Economic History, 17(4), 389-407.

Esteves, Rui, and João Tovar Jalles. 2016. "Like Father Like Sons? The Cost of Sovereign Defaults in Reduced Credit to the Private Sector.” Journal of Money, Credit and Banking 48 (7): 151545.

Esteves, Rui, Sean Kenny, and Jason Lennard. 2021. "The Aftermath of Sovereign Debt Crises: A Narrative Approach.” CEPR Discussion Paper 16166.

Fang, Chuck, Julian Schumacher, and Christoph Trebesch. 2020. "Restructuring Sovereign Bonds: Holdouts, Haircuts and the Effectiveness of CACs.” ECB Working Paper 2366.

Farhi, Emmanuel, and Jean Tirole. 2018. "Deadly Embrace: Sovereign and Financial Balance Sheets Doom Loops.” Review of Economic Studies 85 (3): 1781-1823.

Feis, Herbert. 1930. Europe, the World's Banker, 1870-1914. New York: W. W. Norton \& Co.

Ferguson, Niall. 2006. "Political Risk and the International Bond Market between the 1848 Revolution and the Outbreak of the First World War.” Economic History Review 59 (1): 70112.

Ferguson, Niall, Andreas Schaab, and Moritz Schularick. 2015. "Central Bank Balance Sheets: Expansion and Reduction since 1900.” CESifo Working Paper 5379.

Ferguson, Niall, Andreas Schaab, and Moritz Schularick. 2020. "Data on Central bank holdings of governments”. Unpublished data. Accessed June 18, 2020.

Ferrando, Annalisa, Alexander Popov, and Gregory F. Udell. 2017. "Sovereign Stress and SMEs' Access to Finance: Evidence from the ECB's SAFE Survey.” Journal of Banking \& Finance 81: 65-80.

Fink, Fabian, and Almuth Scholl. 2016. “A Quantitative Model of Sovereign Debt, Bailouts and Conditionality.” Journal of International Economics 98 (C): 176-90. 
Fisher, Chay, and Christopher Kent. 1999. “Two Depressions, One Banking Collapse.” RBA Research Discussion Papers 1999-06.

Fishlow, Albert. 1985. "Lessons from the Past: Capital Markets during the 19th Century and the Interwar Period.” International Organization 39 (3): 383-439.

Flandreau, Marc. 1997. "Central Bank Cooperation in Historical Perspective: A Skeptical View." The Economic History Review 50 (4): 735-63.

Flandreau, Marc, and Juan H. Flores. 2009. "Bonds and Brands: Foundations of Sovereign Debt Markets, 1820-1830.” The Journal of Economic History 69 (3): 646-84.

Flandreau, Marc, and Juan H. Flores. 2012. "Bondholders versus Bond-Sellers? Investment Banks and Conditionality Lending in the London Market for Foreign Government Debt, 1815-1913.” European Review of Economic History 16 (4): 356-83.

Flandreau, Marc, Norbert Gaillard, and Frank Packer. 2011. "To Err Is Human: US Rating Agencies and the Interwar Foreign Government Debt Crisis.” European Review of Economic History 15 (3): 495-538.

Flandreau, Marc, Norbert Gaillard, and Ugo Panizza. 2010. "Conflicts of Interest, Reputation, and the Interwar Debt Crisis: Banksters or Bad Luck?” CEPR Discussion Paper 7705.

Friedman, Milton, and Anna J. Schwartz. 1963. A Monetary History of the United States, 18671960. Princeton: Princeton University Press.

Furceri, Davide, and Aleksandra Zdzienicka. 2012. “How Costly Are Debt Crises?” Journal of International Money and Finance 31 (4): 726-42.

Galofré-Vilà, Gregori, Christopher M. Meissner, Martin McKee, and David Stuckler. 2019. “The Economic Consequences of the 1953 London Debt Agreement.” European Review of Economic History 23 (1): 1-29.

Gelos, Gaston, Ratna Sahay, and Guido Sandleris. 2011. "Sovereign Borrowing by Developing countries: What Determines Market Access?” Journal of International Economics, 83(2), 243254.

Gelpern, Anna, Sebastian Horn, Scott Morris, Brad Parks, and Christoph Trebesch. 2021. "How China Lends: A Rare Look into 100 Debt Contracts with Foreign Governments.” Unpublished.

Gennaioli, Nicola, Alberto Martin, and Stefano Rossi. 2014. "Sovereign Default, Domestic Banks, and Financial Institutions.” Journal of Finance 69 (2): 819-66.

Ghosh, Atish R., Jun I. Kim, Enrique G. Mendoza, Jonathan D. Ostry, and Mahvash S. Qureshi. 2013. "Fiscal Fatigue, Fiscal Space and Debt Sustainability in Advanced Economies.” The Economic Journal 123 (566): 4-30.

Graf von Luckner, Clemens, Josefin Meyer, Carmen M. Reinhart, and Christoph Trebesch. 2021. "External Sovereign Debt Restructurings: Delay and Replay.” Vox EU, March.

González-Rozada, Martín, and Eduardo Levy Yeyati. 2008. "Global Factors and Emerging Market Spreads.” Economic Journal 118 (533): 1917-36.

Gordon, Grey, and Pablo Guerron-Quintana. 2019. "A Quantitative Theory of Hard and Soft Sovereign Defaults." Unpublished.

Gourinchas, Pierre-Olivier, and Olivier Jeanne. 2013. "Capital Flows to Developing Countries: The Allocation Puzzle.” Review of Economic Studies 80 (4): 1484-1515.

Gourinchas, Pierre-Olivier, Philippe Martin, and Todd E. Messer. 2020. "The Economics of Sovereign Debt, Bailouts and the Eurozone Crisis.” NBER Working Paper 27403.

Gourinchas, Pierre-Olivier, Thomas Philippon, and Dimitri Vayanos. 2017. "The Analytics of the Greek Crisis.” NBER Macroeconomics Annual 31 (1): 1-81.

Gros, Daniel. 2012. "A Simple Model of Multiple Equilibria and Default.” Unpublished.

Guembel, Alexander, and Oren Sussman. 2009. "Sovereign Debt without Default Penalties.” Review of Economic Studies 76 (4): 1297-1320.

Gulati, Mitu, and Robert E. Scott. 2012. The Three and a Half Minute Transaction: Boilerplate and the Limits of Contract Design. Chicago: University of Chicago Press. 
Hale, Galina, Peter Jones, and Mark Spiegel. 2020. “The Rise in Home Currency Issuance” Journal of International Economics, Volume 122, January, DOI: 103256.

Hall, George, et al. 2019. Debts and Entanglements between the Wars, edited by Era Dabla-Norris. Washington, DC: International Monetary Fund.

He, Zhiguo, and Wei Xiong. 2012. "Rollover Risk and Credit Risk.” The Journal of Finance 67 (2): 391-430.

Hébert, Benjamin, and Jesse Schreger. 2017. "The Costs of Sovereign Default: Evidence from Argentina.” American Economic Review 107 (10): 3119-45.

Herndon, Thomas, Michael Ash, and Robert Pollin. 2014. "Does High Public Debt Consistently Stifle Economic Growth? A Critique of Reinhart and Rogoff.” Cambridge Journal of Economics 38 (2): 257-79.

Hilscher, Jens, Alon Raviv, and Ricardo Reis. 2014. "Inflating Away the Public Debt? An Empirical Assessment.” Working Paper 74, Brandeis University.

Horn, Sebastian. 2020. "Official Lending, Idiosyncratic Shocks and International Risk-Sharing.” Dissertation Chapter, University of Munich.

Horn, Sebastian, Carmen M. Reinhart, and Christoph Trebesch. 2021. “China’s Overseas Lending.” Journal of International Economics, forthcoming.

Horn, Sebastian, Carmen M. Reinhart, and Christoph Trebesch. 2020. "Coping with Disasters: Two Centuries of International Official Lending.” NBER Working Paper 27343.

IMF. 2013. "Sovereign debt restructuring - Recent Developments and Implications for the Fund's Legal and Policy Framework, Policy Paper April 2013.

IMF. 2011. "Managing Sovereign Debt and Debt Markets through a Crisis - Practical Insights and Policy Lessons.” Report, Monetary and Capital Markets Department.

IMF. 2021. "World Bank Group and International Monetary Fund support for debt relief under the common framework and beyond”, Policy Paper No. 2021/022.

Jalil, Andrew J. 2015. "A New History of Banking Panics in the United States, 1825-1929: Construction and Implications.” American Economic Journal: Macroeconomics 7 (3): 295330.

Jeanne, Olivier, and Jeromin Zettelmeyer. 2001. "International Bailouts, Moral Hazard and Conditionality.” Economic Policy 16 (33): 408-32.

Jeanne, Olivier, Jonathan D. Ostry, and Jeromin Zettelmeyer. 2008. “A Theory of International Crisis Lending and IMF Conditionality.” IMF Working Paper 08/236.

Jeanneret, Alexandre, and Slim Souissi. 2016. "Sovereign Defaults by Currency Denomination.” Journal of International Money and Finance 60 (C): 197-222.

Jordà, Òscar, Moritz Schularick, and Alan M. Taylor. 2017. "Macrofinancial History and the New Business Cycle Facts.” NBER Macroeconomics Annual 31: 213-63.

Jordà, Oscar, Moritz Schularick, and Alan M. Taylor. 2021. "Macrohistory Database." MacroFinance and MacroHistory Lab. https://www.macrohistory.net/database/

Kalemli-Ozcan, Sebnem, Luc Laeven, and David Moreno. 2018. "Debt Overhang, Rollover Risk, and Corporate Investment: Evidence from the European Crisis.” NBER Working Paper 24555.

Kaminsky, Graciela L., and Carmen M. Reinhart. 1999. "The Twin Crises: The Causes of Banking and Balance-of-Payments Problems.” American Economic Review 89(3): 473-500.

Kohlscheen, Emanuel. 2007. "Why Are There Serial Defaulters? Evidence from Constitutions." Journal of Law and Economics 50 (4): 713-30.

Krause, Michael U., and Stéphane Moyen. 2016. "Public Debt and Changing Inflation Targets." American Economic Journal: Macroeconomics 8 (4): 142-76.

Krishnamurthy, Arvind, and Tyler Muir. 2017. "How Credit Cycles across a Financial Crisis.” NBER Working Paper 23850. 
Krishnamurthy, Arvind, Stefan Nagel, and Annette Vissing-Jorgensen. 2018. "ECB Policies Involving Government Bond Purchases: Impact and Channels.” Review of Finance 22 (1): 144.

Kriwoluzky, Alexander, Gernot J. Müller, and Martin Wolf. 2019. "Exit Expectations and Debt Crises in Currency Unions.” Journal of International Economics 121: 103253.

Krugman, Paul. 1988. "Financing vs. Forgiving a Debt Overhang." Journal of Development Economics 29 (3): 253-68.

Kumar, Manmohan S., and Jaejoon Woo. 2015. "Public Debt and Growth.” Economica 82 (328): 705-39.

Kuvshinov, Dmitry, and Kaspar Zimmermann. 2019. "Sovereigns Going Bust: Estimating the Cost of Default.” European Economic Review 119: 1-21.

Laeven, Luc, and Fabian Valencia. 2013. “Systemic Banking Crises Database.” IMF Economic Review 61 (2): 225-70.

Laeven, Luc, and Fabian Valencia. 2018. “Systemic Banking Crises Revisited.” IMF Working Paper $18 / 206$.

Lane, Philip R. 2012. “The European Sovereign Debt Crisis.” Journal of Economic Perspectives 26 (3): 49-68.

Lang, Valentin, David Mihalyi, and Andrea Presbitero. 2020. "Borrowing after Sovereign Debt Relief”. Unpublished.

Lindert, Peter H., and Peter J. Morton. 1989. “How Sovereign Debt Has Worked.” In Developing Country Debt and Economic Performance, Volume 1: The International Financial System, edited by Jeffrey D. Sachs, 39-106. Chicago: University of Chicago Press.

Lipson, Charles. 1985. Standing Guard: Protecting Foreign Capital in the Nineteenth and Twentieth Centuries. Berkeley: University of California Press.

Lloyd, Wildon. 1934. The European War Debts and Their Settlement. New York: Committee for the consideration of inter-governmental debts.

Longstaff, Francis A., Jun Pan, Lasse H. Pedersen, and Kenneth J. Singleton. 2011. "How Sovereign Is Sovereign Credit Risk?” American Economic Journal: Macroeconomics 3 (2): 75-103.

Lorenzoni, Guido, and Iván Werning. 2019. "Slow Moving Debt Crises.” American Economic Review 109 (9): 3229-63.

Maerean, Andreea-Alexandra, and Kris James Mitchener. 2016a. "How Important were Doom Loops?” Ph.D. Dissertation, University of Southern Denmark, Chapter 4.

Maerean, Andreea-Alexandra, and Kris James Mitchener. 2016b. "Data on Historical Doom Loops”. Unpublished data. Accessed August 7, 2017.

Maerean, Andreea-Alexandra, and Paul Sharp. 2018. "Sovereign Debt and Supersanctions in Emerging Markets: Evidence from Four Southeast European Countries, 1878-1913.” Unpublished. University of Southern Denmark.

Manes, Alfred. 1918. Staatsbankrotte: Wirtschaftliche und rechtliche Betrachtungen. Berlin: Karl Siegismund.

Marichal, Carlos. 1989. A Century of Debt Crises in Latin America: From Independence to the Great Depression, 1820-1930. Princeton: Princeton University Press.

Marichal, Carlos. 2014. "Historical Reflections on the Causes of Financial Crises: Official Investigations, Past and Present, 1873-2011.” Journal of the Spanish Economic History Association 10 (02): 81-91.

Martin, Philippe, and Thomas Philippon. 2017. "Inspecting the Mechanism: Leverage and the Great Recession in the Eurozone.” American Economic Review 107 (7): 1904-37.

Mauro, Paolo, Nathan Sussman, and Yishay Yafeh. 2002. "Emerging Market Spreads: Then versus Now.” Quarterly Journal of Economics 117 (2): 695-733.

Mauro, Paulo, and Jing Zhou. 2020. “r minus g negative: Can We Sleep More Soundly?” IMF Working Paper 20/52. 
Mauro, Paolo, Rafael Romeu, Ariel Binder and Asad Zaman. 2013a. "Historical Public Finance Dataset.” International Monetary Fund.

Mauro, Paolo, Rafael Romeu, Ariel Binder and Asad Zaman. 2013b. “A Modern History of Fiscal Prudence and Profligacy,” IMF Working Paper No. 13/5, International Monetary Fund, Washington, DC.

Mendoza, Enrique G., and Jonathan D. Ostry. 2008. "International Evidence on Fiscal Solvency: Is Fiscal Policy ‘Responsible'?” Journal of Monetary Economics 55 (6): 1081-93.

Mendoza, Enrique G., and Vivian Z. Yue. 2012. "A General Equilibrium Model of Sovereign Default and Business Cycles.” Quarterly Journal of Economics 127 (2): 889-946.

Mehrotra, Neil R., and Dmitriy Sergeyev. 2019. “Debt Sustainability in a Low Interest Rate World.” Unpublished.

Meyer, Josefin. 2021. "Domestic vs. Foreign Debt: Discrimination in Sovereign Debt Restructuring, 1900-2020.” Unpublished.

Meyer, Josefin, Carmen M. Reinhart, and Christoph Trebesch. 2019. "Sovereign Bonds since Waterloo.” forthcoming Quarterly Journal of Economics.

Michie, Ranald C. 1999. The London Stock Exchange: A History. Oxford: Oxford University Press.

Mikesell, Raymond. 1962. U.S. Private and Government Investment Abroad. Eugene: University of Oregon Press.

Mitchener, Kris James. 2014. “The Diabolic Loop: Precedents and Legacies.” In Bearing the losses from bank and sovereign default in the Eurozone, edited by Franklin Allen, Elena Carletti, Joanna Gray, 165-180. Philadelphia: FIC Press.

Mitchener, Kris J., and Gonçalo Pina. 2020. “Pegxit Pressure.” Journal of International Money and Finance 107: 102191.

Mitchener, Kris James, and Marc D. Weidenmier. 2005. "Empire, Public Goods, and the Roosevelt Corollary.” Journal of Economic History 65 (3): 658-92.

Mitchener, Kris James, and Marc D. Weidenmier. 2008. "The Baring Crisis and the Great Latin American Meltdown of the 1890s.” Journal of Economic History 68 (2): 462-500.

Mitchener, Kris James, and Marc D. Weidenmier. 2010. "Supersanctions and Sovereign Debt Repayment.” Journal of International Money and Finance 29 (1): 19-36.

Mitchener, Kris James, and Marc D. Weidenmier. 2015. "Was the Classical Gold Standard Credible on the Periphery? Evidence from Currency Risk.” Journal of Economic History 75 (2): 479511.

Mody, Ashoka, and Damiano Sandri. 2012. "The Eurozone Crisis: How Banks and Sovereigns Came to Be Joined at the Hip.” Economic Policy 27 (70): 199-230.

Morelli, Juan, Pablo Ottonello, and Diego Perez. 2019. “Global Banks and Systemic Debt Crises”. Unpublished.

Moulton, Harold G., and Leo Pasvolsky. 1932. "War Debts and World Prosperity." Washington, D.C.: Brookings Institution

Müller, Andreas, Kjetil Storesletten, and Fabrizio Zilibotti. 2019. "Sovereign Debt and Structural Reforms.” American Economic Review 109 (12): 4220-59.

Neumeyer, Pablo A., and Fabrizio Perri. 2005. "Business Cycles in Emerging Economies: The Role of Interest Rates.” Journal of Monetary Economics 52 (2): 345-80.

Niepmann, Friederike, and Tim Schmidt-Eisenlohr. 2013. "Bank Bailouts, International Linkages, and Cooperation.” American Economic Journal: Economic Policy 5 (4): 270-305.

North, Douglass C., and Barry R. Weingast. 1989. "Constitutions and Commitment: The Evolution of Institutions Governing Public Choice in Seventeenth-Century England“.Journal of Economic History 49 (4): 803-832.

Obstfeld, Maurice. 1996. "Models of Currency Crises with Self-Fulfilling Features.” European Economic Review 40 (3): 1037-47. 
Ongena, Steven, Alexander Popov, and Neeltje Van Horen. 2019. “The Invisible Hand of the Government: Moral Suasion during the European Sovereign Debt Crisis.” American Economic Journal: Macroeconomics 11 (4): 346-79.

Oosterlinck, Kim. 2013. "Sovereign debt defaults: insights from History." Oxford Review of Economic Policy 29 (4): 697-714.

Oosterlinck, Kim, Xavier De Scheemaekere, and Ariane Szafarz. 2015. "Identifying economic crises: insights from history.” Financial History Review 22(1): 1-18.

Oosterlinck, Kim, Loredana Ureche-Rangau, and Jacques-Marie Vaslin. 2014. "Baring, Wellington and the Resurrection of French Public Finances Following Waterloo.” Journal of Economic History 74 (4): 1072-1102.

Ottonello, Pablo and Diego Perez. 2019. “The Currency Composition of Sovereign Debt.” American Economic Journal: Macroeconomics, 11(3): 174-208.

Panizza, Ugo, and Andrea F. Presbitero. 2014. "Public Debt and Economic Growth: Is There a Causal Effect?” Journal of Macroeconomics 41: 21-41.

Panizza, Ugo, Federico Sturzenegger, and Jeromin Zettelmeyer. 2009. “The Economics and Law of Sovereign Debt and Default.” Journal of Economic Literature 47 (3): 651-98.

Perez, Diego J. 2015. "Sovereign Debt, Domestic Banks and the Provision of Public Liquidity.” Unpublished.

Pescatori, Andrea, and Amadou N. R. Sy. 2007. “Are Debt Crises Adequately Defined?” IMF Staff Papers 54 (2): 306-37.

Phan, Toàn, and Mark L.J. Wright. 2019. "Country Size, Reputation and Sovereign Debt.” Unpublished.

Popov, Alexander, and Neeltje Van Horen. 2014. "Exporting Sovereign Stress: Evidence from Syndicated Bank Lending During the Euro Area Sovereign Debt Crisis.” Review of Finance 19(5): 1825-1866.

Pitchford, Rohan, and Mark L. J. Wright. 2012. "Holdouts in Sovereign Debt Restructuring: A Theory of Negotiation in a Weak Contractual Environment." Review of Economic Studies 79 (2): 812-37.

Reinhart, Carmen, Kenneth S. Rogoff, and Miguel A. Savastano. 2003. "Debt Intolerance.” Brookings Papers on Economic Activity 34 (1): 1-74.

Reinhart, Carmen M., and Kenneth S. Rogoff. 2009. This Time Is Different: Eight Centuries of Financial Folly. Princeton: Princeton University Press.

Reinhart, Carmen M., and Kenneth S. Rogoff. 2009. "Replication data for: This Time is Different: Eight Centuries of Financial Folly." Princeton University Press [publisher], *Harvard University [distributor]*, https://scholar.harvard.edu/rogoff/time-different—data-files.

Reinhart, Carmen M., and Kenneth S. Rogoff. 2010. "Growth in a Time of Debt." American Economic Review 100 (2): 573-78.

Reinhart, Carmen M., and Kenneth S. Rogoff. 2011a. "From Financial Crash to Debt Crisis.” American Economic Review 101 (5): 1676-1706.

Reinhart, Carmen M., and Kenneth S. Rogoff. 2011b. “The Forgotten History of Domestic Debt.” Economic Journal 121 (552): 319-50.

Reinhart, Carmen M., and Kenneth S. Rogoff. 2015. "Financial and Sovereign Debt Crises; Some Lessons Learned and Those Forgotten.” Journal of Banking and Financial Economics 2 (4): 517.

Reinhart, Carmen M., Vincent R. Reinhart, and Kenneth S. Rogoff. 2012. "Public Debt Overhangs: Advanced-Economy Episodes since 1800.” Journal of Economic Perspectives 26 (3): 69-86.

Reinhart, Carmen M., Vincent R. Reinhart, and Kenneth S. Rogoff. 2015. "Dealing with Debt.” Journal of International Economics 96: 43-55.

Reinhart, Carmen M., and M. Belen Sbrancia. 2015. "The Liquidation of Government Debt.” Economic Policy 30 (82): 291-333. 
Reinhart, Carmen M., and Christoph Trebesch. 2015a. "The Pitfalls of External Dependence: Greece, 1829-2015." Brookings Papers on Economic Activity 2015(2): 307-328.

Reinhart, Carmen M., and Christoph Trebesch. 2015b. "The International Monetary Fund: 70 Years of Reinvention," NBER Working Paper 21805.

Reinhart, Carmen M., and Christoph Trebesch. 2016a. "Sovereign Debt Relief and Its Aftermath." Journal of the European Economic Association 14 (1): 215-51.

Reinhart, Carmen M., and Christoph Trebesch. 2016b. "The International Monetary Fund: 70 Years of Reinvention," Journal of Economic Perspectives 30(1): 3-28.

Richardson, Gary. 2007. "Categories and causes of bank distress during the Great Depression, 19291933: The illiquidity versus insolvency debate revisited.” Explorations in Economic History 44: 588-607.

Roch, Francisco, and Harald Uhlig. 2018. "The Dynamics of Sovereign Debt Crises and Bailouts.” Journal of International Economics 114: 1-13.

Roubini, Nouriel, and Brad Setser. 2004. Bailouts or Bail-Ins? Responding to Financial Crises in Emerging Economies. Washington, DC.: Peterson Institute Press

Scheubel, Beatrice, and Livio Stracca. 2016. "What Do We Know About the Global Financial Safety Net? Rationale, Data, and Possible Evolution.” ECB Occasional Paper 177.

Schlegl, Matthias, Christoph Trebesch, and Mark L. J. Wright. 2019. “The Seniority Structure of Sovereign Debt.” NBER Working Paper 25793.

Schneider, Christina J., and Jennifer L. Tobin. 2020. "The Political Economy of Bilateral Bailouts.” International Organization 74 (1): 1-29.

Schultz, Kenneth A., and Barry R. Weingast. 2003. "The Democratic Advantage: Institutional Foundations of Financial Power in International Competition.” International Organization 57 (1): 3-42.

Schumacher, Julian, Christoph Trebesch, and Henrik Enderlein. 2015. "What Explains Sovereign Debt Litigation?” Journal of Law and Economics 58 (3): 585-623.

Schumacher, Julian, Christoph Trebesch, and Henrik Enderlein. 2021. "Sovereign Defaults in Court.” Journal of International Economics vol. 131.

Shleifer, Andrei. 2003. “Will the Sovereign Debt Market Survive?” American Economic Review 93 (2): 85-90.

Steinkamp, Sven, and Frank Westermann. 2014. “The Role of Creditor Seniority in Europe's Sovereign Debt Crisis.” Economic Policy 29 (79): 495-552.

Stoppok, Lucie, and Christoph Trebesch. 2022. "Sovereign Debt: The One Million Bonds Project" Unpublished paper and data. Accessed February 9, 2022.

Straumann, Tobias. 2019. 1931: Debt, Crisis, and the Rise of Hitler. Oxford: Oxford University Press.

Sturzenegger, Federico, and Jeromin Zettelmeyer. 2006. Debt Defaults and Lessons from a Decade of Crises. Cambridge: MIT Press.

Suter, Christian. 1992. Debt Cycles in The World-Economy: Foreign Loans, Financial Crises, And Debt Settlement, 1820-1990. Boulder, CO: Westview Press.

Taylor, Alan M. 2015. "Credit, Financial Stability, and the Macroeconomy." Annual Review of Economics 7 (1): 309-39.

Tirole, Jean. 2015. “Country Solidarity in Sovereign Crises.” American Economic Review 105 (8): 2333-63.

Tomz, Michael. 2007. Reputation and International Cooperation: Sovereign Debt across Three Centuries. Princeton, NJ,:Princeton University Press.

Tomz, Michael, and Mark L.J. Wright. 2013. "Empirical Research on Sovereign Debt and Default.” Annual Review of Economics 5 (1): 247-72.

Tooze, Adam. 2018. Crashed: How a Decade of Financial Crises Changed the World. London: Penguin. 
Trebesch, Christoph. 2019. "Resolving Sovereign Debt Crises: The Role of Political Risk.” Oxford Economic Papers 71 (2): 421-44.

Trebesch, Christoph, and Michael Zabel. 2017. "The Output Costs of Hard and Soft Sovereign Default.” European Economic Review 92: 416-32.

Tuncer, Ali Coskun. 2015. Sovereign Debt and International Financial Control: The Middle East and the Balkans, 1870 - 1914. London: Palgrave Macmillan.

Uribe, Martin, and Vivian Z. Yue. 2006. "Country Spreads and Emerging Countries: Who Drives Whom?” Journal of International Economics 69 (1): 6-36.

Van Rijckeghem, Caroline, and Beatrice Weder. 2009. "Political Institutions and Debt Crises." Public Choice 138 (3): 387-408.

Vizcarra, Catalina. 2009. "Guano, Credible Commitments, and Sovereign Debt Repayment in Nineteenth-Century Peru.” Journal of Economic History 69 (2): 358-87.

Waibel, Michael. 2011. Sovereign Defaults before International Courts and Tribunals. Cambridge: Cambridge University Press.

Wicker, Elmus. 1996. The Banking Panics of the Great Depression. New York: Cambridge University Press.

Winkler, Max. 1933. Foreign Bonds: An Autopsy. Philadelphia: Roland Swain.

Yared, Pierre. 2019. "Rising Government Debt: Causes and Solutions for a Decades-Old Trend.” Journal of Economic Perspectives 33 (2): 115-40.

Zettelmeyer, Jeromin, Christoph Trebesch, and Mitu Gulati. 2013. “The Greek Debt Restructuring: An Autopsy.” Economic Policy 28 (75): 513-63. 